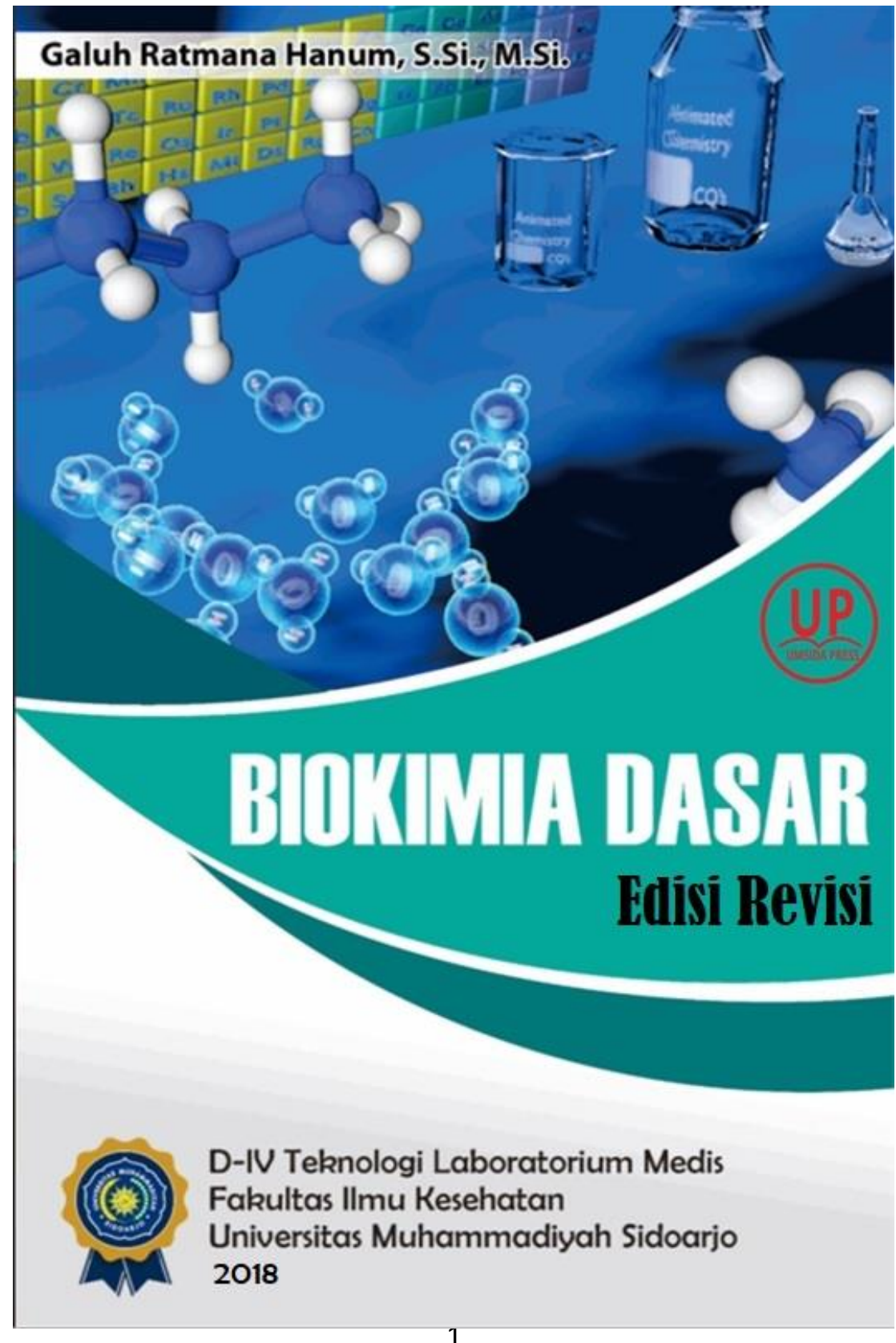




\section{BUKU AJAR \\ BIOKIMIA DASAR}

Edisi Revisi

\section{Penulis}

Galuh Ratmana Hanum, S.Si., M.Si

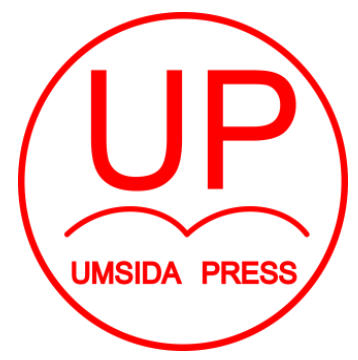

Diterbitkan oleh UMSIDA PRESS

JI. Mojopahit 666 B Sidoarjo

ISBN: 978-602-5914-14-0

Copyright@2018.

Authors

All rights reserved 


\section{BUKU AJAR}

BIOKIMIA DASAR

\section{Penulis :}

Galuh Ratmana Hanum, S.Si., M.Si

\section{ISBN :}

978-602-5914-14-0

\section{Editor :}

Septi Budi Sartika, M.Pd

M. Tanzil Multazam , S.H., M.Kn.

\section{Copy Editor :}

Fika Megawati, S.Pd., M.Pd.

Design Sampul dan Tata Letak :

Mochamad Nashrullah, S.Pd

\section{Penerbit :}

UMSIDA Press

\section{Redaksi :}

Universitas Muhammadiyah Sidoarjo

Jl. Mojopahit No 666B

Sidoarjo, Jawa TImur

Cetakan pertama, Agustus 2018

(C) Hak cipta dilindungi undang-undang

Dilarang memperbanyak karya tulis ini dengan suatu apapun tanpa ijin tertulis dari penerbit. 


\section{KATA PENGANTAR}

Alhamdulillahirabbil'aalamin, segala puja dan puji syukur penulis panjatkan kepada Allah Yang Maha Esa, tanpa karuniaNya tidak mungkin bukuajar BIOKIMIA DASAR ini terselesaikan tepat waktu mengingat tugas dan kewajiban lain yang bersamaan. Buku ini ditulis berdasarkan keinginan penulis yang sering mengamati perilaku mahasiswa pada saat pembelajaran mata kuliah biokimia seperti kurangnya referensi yang digunakan dan minat membaca mahasiswa yang masih kurang. Berdasarkan kondisi tersebut, penulis berusaha menyusun buku ini. Buku ini memuat tentang pengertian, fungsi, klasifikasi dan identifikasi makromolekul. Terselesaikannya penulisan buku ini tidak terlepas dari bantuan beberapa pihak. Penulis menyampaikan terima kasih kepada UMSIDA karena telah memberikan kesempatan kepada penulis. Dengan kesempatan tersebut, dapat mendukung penulis dalam upaya meningkatkan kualitas diri dan karya untuk waktu mendatang. Meskipun telah berusaha untuk menghindari kesalahan, penulis menyadari bahwa buku ini masih mempunyai kekurangan. Karena itu, penulis berharap supaya pembaca berkenan menyampaikan kritikan. Kritik merupakan perhatian supaya dapat menuju kesempurnaan. Akhir kata, penulis berharap semoga buku ini bermanfaat bagi pembaca.

Sidoarjo, 30 Juli 2018

Galuh Ratmana Hanum, S.Si., M.Si 


\section{DAFTAR ISI}

KATA PENGANTAR .............................................................. ii

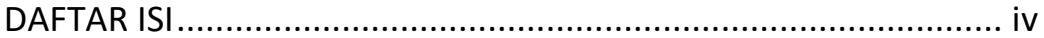

\section{BAB I PENGANTAR BIOKIMIA}

1.1 Pendahuluan ...................................................................... 1

1.2 Manfaat Ilmu Biokimia Dalam Kehidupan .............................. 3

1.3 Hubungan Antara Biokimia Dan Ilmu Yang Lain ..................... 3

1.4 Organisasi Makhluk Hidup......................................................... 4

1.5 Biomolekul Kompleks Penyusun Tubuh.................................. 8

1.6 Unsur Penyusun Tubuh ................................................. 9

1.7 Kaitan IImu Biokimia Dengan Al-Quran ................................ 11

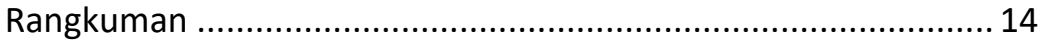

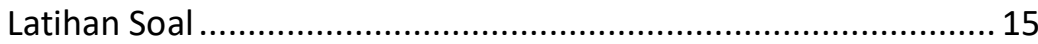

\section{BAB II KARBOHIDRAT}

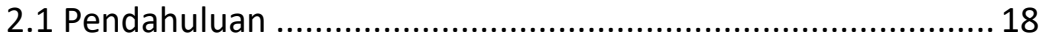

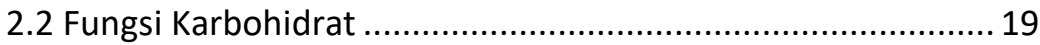

2.3 Klasifikasi Karbohidrat .......................................................... 19

2.4 Penyakit-Penyakit Yang Berhubungan Dengan Karbohidrat... 34

2.5 Identifikasi Karbohidrat ...................................................... 35

Rangkuman ..................................................................... 46

Latihan Soal .......................................................................... 48

BAB III ASAM AMINO DAN PROTEIN

3.1 Pendahuluan .................................................................. 51

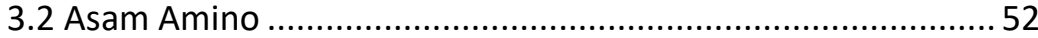

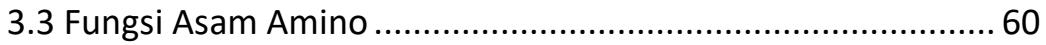

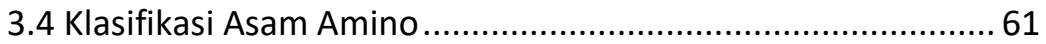

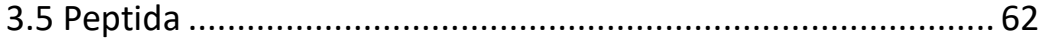

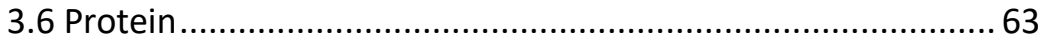

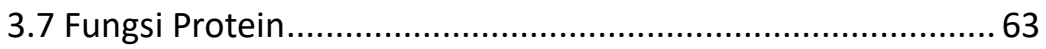




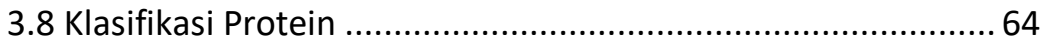

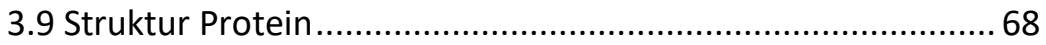

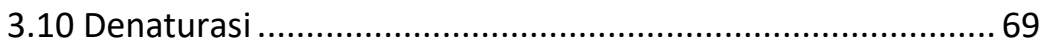

3.11 Penyakit-Penyakit Yang Berhubungan Dengan Protein ........ 71

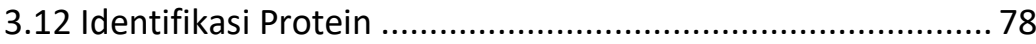

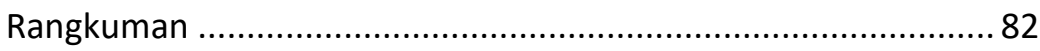

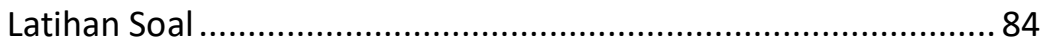

BAB IV LIPID

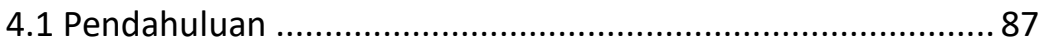

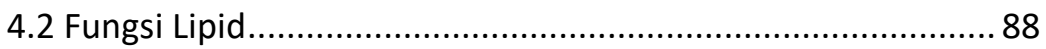

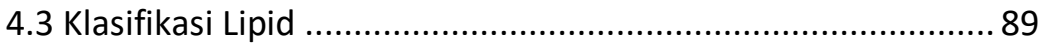

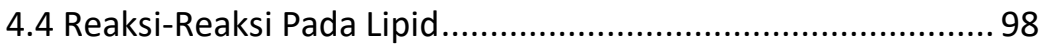

4.5 Penyakit-Penyakit Yang Berhubungan Dengan Lipid ............ 101

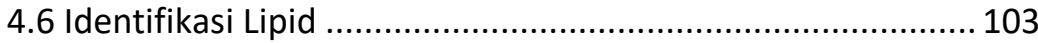

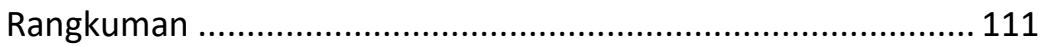

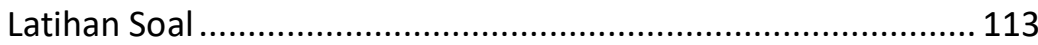

BAB V ASAM NUKLEAT

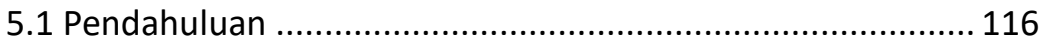

5.2 Komponen Penyusun Asam Nukleta ................................... 117

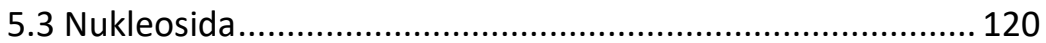

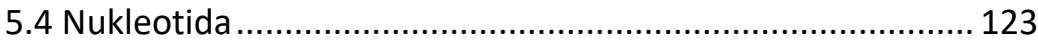

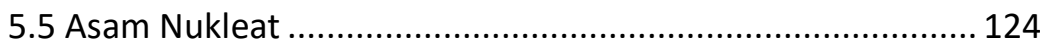

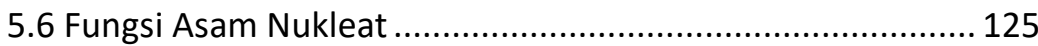

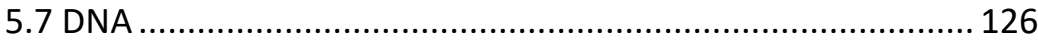

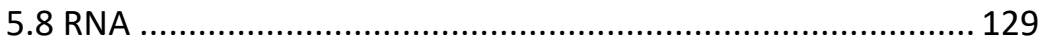

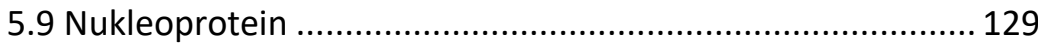

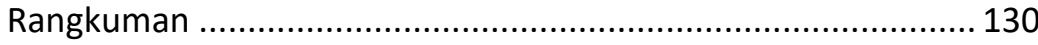

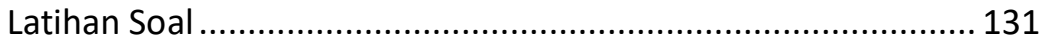




\section{BAB VI ENZIM}

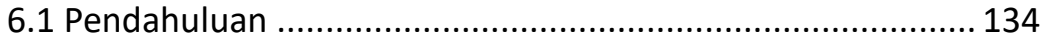

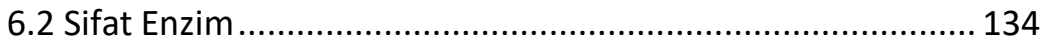

6.3 Klasifikasi Enzim .............................................................. 135

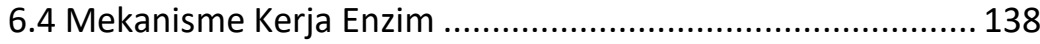

6.5 Aktivitas Enzim .......................................................... 140

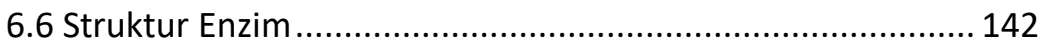

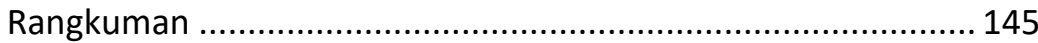

Latihan Soal .......................................................................... 146

BAB VII METABOLISME

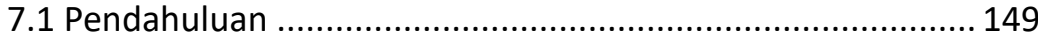

7.2 Metabolisme Karbohidrat ................................................. 149

7.3 Metabolisme Lemak ......................................................... 153

7.4 Metabolisme Protein .......................................................... 155

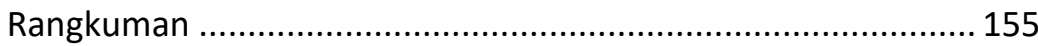

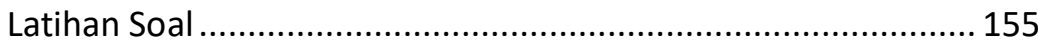

Daftar Pustaka ...................................................................... 157 


\section{BAB I}

\section{PENGANTAR BIOKIMIA}

\begin{tabular}{|c|c|}
\hline Tujuan Instruksional & Materi \\
\hline $\begin{array}{l}\text { Mahasiswa memahami } \\
\text { tentang perkembangan } \\
\text { ilmu biokimia dan } \\
\text { keterkaitannya dengan } \\
\text { Al-Quran sehingga dapat } \\
\text { diterapkan dalam } \\
\text { bidang kesehatan sesuai } \\
\text { dengan perkembangan } \\
\text { sains dan teknologi. }\end{array}$ & $\begin{array}{l}\text { 1.1 Pendahuluan } \\
\text { 1.2 Manfaat Ilmu Biokimia Dalam } \\
\text { Kehidupan } \\
\text { 1.3 Hubungan Antara Biokimia Dan } \\
\text { Ilmu Yang Lain } \\
\text { 1.4 Organisasi Makhluk Hidup } \\
\text { 1.5 Biomolekul Kompleks Penyusun } \\
\text { Tubuh } \\
\text { 1.6 Unsur Penyusun Tubuh } \\
\text { 1.7 Kaitan Ilmu Biokimia Dengan Al- } \\
\text { Quran }\end{array}$ \\
\hline
\end{tabular}

\subsection{Pendahuluan}

Sejarah awal mula penelitian biokimia terjadi pada abad XVII, Robert Hooke melakukan observasi terhadap sel-sel dengan menggunakan mikroskop sehingga dapat meningkatkan pemahaman atas struktur yang kompleks pada makhluk hidup.

Pada abad XVIII Karl Wilhelm Scheele ahli kimia Swedia telah melakukan penelitian mengenai susunan kimia jaringan pada tumbuhan dan hewan. Selain itu, Karl Wilhelm Scheele juga mengisolasi asam oksalat, asam laktat, asam sitrat, beberapa ester dan kasein dari bahan alam. Kemudian pada tahun 1828 Friedrich Wohler menunjukkan bahwa urea senyawa yang terdapat dalam urin, dibuat dalam laboratorium dengan cara memanaskan alkali sianat dan garam amonium. Awalnya Friedrich Wohler mengharapkan garam amonium sianat sebagai hasilnya, tetapi yang diperoleh adalah urea. 
Istilah biokimia dikemukakan oleh Karl Neuberg, seorang ahli kimia jerman tahun 1903 dan biokimia memperoleh bentuk yang nyata sebagai suatu bidang studi. Penemuan dua bersaudara Eduard dan Hans Buchner menyatakan bahwa ekstrak dari sel ragi yang telah mati tetap dapat menyebabkan terjadinya proses peragian atau fermentasi gula menjadi alkohol. Penemuan ini sebagai pembuka analisis reaksi biokimia dan proses biokimia dengan alat laboratorium (in vitro) dan dalam makhluk hidup (in vivo).

Perkembangan biokimia juga tidak terlepas dari perkembangan yang terjadi pada bidang pengetahuan genetika. Gagasan tentang adanya gen, yakni unit pembawa sifat-sifat yang diturunkan oleh individu, timbul dari karya Gregor Mendel pada pertengahan abad XIX dan menjelang abad XX diketahui bahwa gen tersebut terdapat pada kromosom. Pada abad XX ini ilmu biokimia mengalami perkembangan pesat.

Biokimia berasal bahasa Yunani dan terdiri dari dua kata yaitu Bios yang berarti kehidupan dan Chemis yang berarti kimia, jika digabungkan Biokimia berarti ilmu yang mempelajari berbagai reaksi kimia kehidupan serta interaksi molekul dalam sel makhluk hidup. Biokimia terdiri dari tiga hukum yang menjadi pokok bahasannya, yaitu hukum biologi, hukum kimia dan hukum biokimia yang jika digabungkan sering disebut super chemistry. Tujuan mempelajari biokimia adalah untuk memahami interaksi molekul-molekul tak hidup yang menghasilkan fenomena kompleks dan efisien yang menjadi ciri-ciri kehidupan serta menjelaskan keseragaman kimia dari kehidupan yang beragam. 


\subsection{Manfaat Ilmu Biokimia Dalam Kehidupan Antara Lain :}

a. Mempermudah dalam mempelajari ilmu-ilmu dasar yang lain seperti kimia organik, biofisika, ilmu gizi, mikrobiologi, genetika, fisiologi dan farmakologi.

b. Digunakan sebagai dasar terapi berbagai penyakit.

c. Mengidentifikasi reaksi yang terjadi pada proses kehidupan sehingga mampu menganalisa terjadinya penyakit atau masalah yang terjadi pada proses tersebut hingga level molekular.

d. Menentukan cara baru dalam menanggulangi penyakit yang berkembang.

e. Menganalisa perkembangan bakteri penyebab penyakit, mempelajari sifatnya dan cara pengendaliannya menggunakan bahan-bahan kimia.

f. Mengetahui fungsi enzim dalam proses metabolisme

g. Dalam bidang pertanian, biokimia memiliki peran dalam pembuatan pestisida dengan cara menghambat enzim di dalam tubuh hama.

\subsection{Hubungan Antara Biokimia Dan Ilmu Yang Lain}

a. Kimia Organik

Mempelajari sifat-sifat biomolekul

b. Biofisika

Memanfaatkan teknik fisika untuk mempelajari struktur biomolekul

c. Ilmu Gizi

Memanfaatkan pengetahuan tentang metabolisme untuk menjelaskan kebutuhan makanan bagi makhluk hidup dalam mempertahan kehidupan normalnya. 
d. Kesehatan

Mencari pemahaman tentang keadaan sakit dari sudut pandang molekuler

e. Mikrobiologi

Menunjukkan bahwa organisme sel tunggal dan virus dapat digunakan sebagai sarana mempelajari jalur-jalur metabolisme dan mekanisme pengendalian metabolisme.

f. Fisiologi

Mempelajari proses kehidupan pada tingkat jaringan dan organisme.

g. Genetika

Mempelajari mekanisme penyusunan identitas biokimia sel.

\subsection{Organisasi Makhluk Hidup}

Makhluk hidup terdiri atas berbagai tingkatan organisasi kehidupan dimulai dari yang paling sederhana hingga tingkatan yang kompleks. Tingkatan organisasi kehidupan dimulai dari molekul, sel, jaringan, organ, sistem organ, individu, populasi, ekosistem, hingga ke tingkatan bioma. Berikut ini penjelasan tentang tingkat organisasi makhluk hidup :

A. Molekul

Molekul didefinisikan sebagai sekelompok atom yang saling berikatan dengan sangat kuat dalam susunan tertentu dan bermuatan netral serta cukup stabil.

B. Sel

Sel merupakan unit organisasi terkecil yang menjadi dasar kehidupan dalam arti biologis. Semua fungsi kehidupan diatur dan berlangsung di dalam sel. Makhluk hidup (organisme) tersusun dari satu sel tunggal 
(uniselular), misalnya bakteri, Archaea, sejumlah fungi dan protozoa) dan banyak sel (multiselular).

C. Jaringan

Jaringan adalah sekumpulan sel yang memiliki bentuk dan fungsi yang sama. Sekumpulan jaringan akan membentuk organ. Cabang ilmu biologi yang mempelajari jaringan adalah histologi. Sedangkan cabang ilmu biologi yang mempelajari jaringan dalam hubungannya dengan penyakit adalah histopatologi.

D. Organ

Organ adalah kumpulan dari berbagai macam jaringan dan melaksanakan suatu tugas tertentu. Beberapa contoh organ tubuh makhluk hidup :

1. Usus

Merupakan bagian dari sistem pencernaan. Disusun dari beberapa jaringan, susunan dari luar ke dalam yaitu :

a. Jaringan ikat serosa, fungsinya untuk menggantungkan usus ke organ lain.

b. Jaringan otot polos memanjang.

c. Jaringan otot polos melingkar.

d. Jaringan ikat longgar.

e. Jaringan otot polos mukosa.

f. Jaringan ikat longgar mukosa.

g. Jaringan epitel silindris yang merupakan jaringan terdalam dari rongga usus.

h. Disamping jaringan-jaringan tersebut di atas terdapat juga jaringan-jaringan lain (jaringan saraf, jaringan darah dan lain-lain) yang menunjang kerja usus. 
2. Trakea/Batang Tenggorok

Merupakan bagian dari sistem pernafasan. Trakea disusun atas 3 lapis jaringan, dari luar ke dalam yaitu:

a. Jaringan ikat padat.

b. Jaringan rulang rawan dan jaringan otot polos.

c. Jaringan epitel silindris berlapis banyak bersilia.

\section{E. Sistem Organ}

Sistem organ adalah Kumpulan dari berbagai organ dan menjalankan tugas tertentu. Sistem organ yang terdapat dalam tubuh manusia antara lain :

Tabel 1.1 Sistem Organ Makhluk Hidup (Harper, 2009)

\begin{tabular}{|c|c|c|c|}
\hline No. & Sistem & Organ & Fungsi \\
\hline 1. & $\begin{array}{l}\text { Sistem } \\
\text { pencernaan }\end{array}$ & $\begin{array}{l}\text { Mulut, faring, } \\
\text { eksofagus, } \\
\text { lambung, usus, hati, } \\
\text { kantong } \\
\text { empedu, } \\
\text { pankreas. }\end{array}$ & $\begin{array}{l}\text { Mencerna } \\
\text { makanan, } \\
\text { mengabsorbsimolek } \\
\text { ul-molekulmakanan } \\
\text { yang sudah } \\
\text { disederhanakan. }\end{array}$ \\
\hline 2. & $\begin{array}{l}\text { Sistem } \\
\text { pernapasan }\end{array}$ & $\begin{array}{l}\text { Hidung, faring, laring, } \\
\text { trakea, brokus, paru- } \\
\text { paru. }\end{array}$ & $\begin{array}{l}\text { Pertukaran gas } \\
\text { (oksigen dan karbon } \\
\text { dioksida). }\end{array}$ \\
\hline 3. & Sistem gerak & Tulang, otot & $\begin{array}{lr}\text { Menyokong } & \text { dan } \\
\text { melindungi } & \text { organ } \\
\text { dalam } & \\
\end{array}$ \\
\hline 4. & $\begin{array}{l}\text { Sistem } \\
\text { transportasi }\end{array}$ & $\begin{array}{l}\text { Jantung, arteri, vena, } \\
\text { kapiler, } \\
\text { limfatik, } \\
\text { limfa. }\end{array}$ & $\begin{array}{l}\text { Mengangkut } \\
\text { oksigen dan sari } \\
\text { makanan ke seluruh } \\
\text { sel-sel tubuh dan } \\
\text { mengangkut zat } \\
\text { hasil metabolisme } \\
\text { yang tidak berguna } \\
\text { keluar dari sel-sel } \\
\text { tubuh, serta }\end{array}$ \\
\hline
\end{tabular}




\begin{tabular}{|c|c|c|c|}
\hline & & & $\begin{array}{l}\text { melindungitubuh } \\
\text { dari penyakit }\end{array}$ \\
\hline 5. & $\begin{array}{l}\text { Sistem } \\
\text { ekskresi }\end{array}$ & $\begin{array}{l}\text { Paru - paru, ginjal, } \\
\text { kulit, dan hati }\end{array}$ & $\begin{array}{l}\text { Mengeluarkan sisa } \\
\text { metabolisme } \\
\text { dari dalam tubuh } \\
\text { dan menjaga } \\
\text { keseimbangan sel } \\
\text { dengan } \\
\text { lingkungannya }\end{array}$ \\
\hline 6. & Sistem saraf & $\begin{array}{l}\text { Otak, serabut saraf, } \\
\text { simpul saraf, medula } \\
\text { spinalis, medula } \\
\text { oblongata. }\end{array}$ & $\begin{array}{l}\text { Menerima dan } \\
\text { merespon rangsang } \\
\text { dari lingkungannya. }\end{array}$ \\
\hline 7. & $\begin{array}{l}\text { Sistem } \\
\text { reproduksi }\end{array}$ & Testes dan ovarium & Perkembangbiakan. \\
\hline
\end{tabular}

F. Individu

Individu merupakan organisme tunggal seperti : seekor tikus, seekor kucing, sebatang pohon jambu, sebatang pohon kelapa, dan seorang manusia. Dalam mempertahankan hidup, setiap jenis individu dihadapkan pada masalah hidup. Misalnya, seekor hewan harus mendapatkan makanan, mempertahankan diri terhadap musuh alaminya, serta memelihara anaknya. Untuk mengatasi masalah tersebut, organisme harus memiliki struktur khusus seperti : duri, sayap, kantung, atau tanduk. Hewan juga memperlihatkan tingkah laku tertentu, seperti membuat sarang atau melakukan migrasi yang jauh untuk mencari makanan. Tingkah laku demikian disebut adaptasi.

G. Populasi

Populasi adalah kumpulan individu sejenis yang hidup pada suatu daerah dan waktu tertentu. Misalnya, 
populasi pohon kelapa dikelurahan Lebo pada tahun 1989 berjumlah 2552 batang. Ukuran populasi berubah sepanjang waktu. Perubahan ukuran dalam populasi ini disebut dinamika populasi.

H. Komunitas

Komunitas ialah kumpulan dari berbagai populasi yang hidup pada suatu waktu dan daerah tertentu yang saling berinteraksi dan mempengaruhi satu sama lain. Komunitas memiliki derajat keterpaduan yang lebih kompleks bila dibandingkan dengan individu dan populasi.

I. Ekosistem

Ekosistem adalah hubungan timbal balik antara makhluk hidup dan lingkungannya. Ilmu yang mempelajari ekosistem disebut ekologi. Antara komunitas dan lingkungannya selalu terjadi interaksi. Komponen penyusun ekosistem adalah produsen (tumbuhan hijau), konsumen (herbivora, karnivora, dan omnivora), dan dekomposer/pengurai (mikroorganisme).

J. Bioma

Definisi bioma dibuat dalam hal kondisi tidak hanya ruang tetapi lebih cocok untuk kelompok masyarakat (tanaman, hewan, mikroba, dll). Klasifikasi bioma bumi dilakukan atas dasar kondisi atau lingkungan di mana organisme hidup.

\subsection{Biomolekul Kompleks Penyusun Tubuh}

Biokimia mempelajari fungsi dan struktur komponen selular biomolekul, seperti Karbohidrat, Protein, Lipid dan Asam Nukleat. 
A. Karbohidrat

Karbohidrat merupakan suatu senyawa organik polihidroksialdehid atau polihidroksiketon. Rumus umum dari karbohidrat adalah $\mathrm{C}_{n}\left(\mathrm{H}_{2} \mathrm{O}\right)_{n}$ atau $\mathrm{C}_{n} \mathrm{H}_{2 n} \mathrm{O}_{n}$. Karbohidrat terdiri dari unsur karbon, hidrogen, dan oksigen.

B. Protein

Protein adalah senyawa organik komplek berbobot molekul besar yang terdiri dari asam amino yang dihubungkan satu sama lain dengan ikatan peptida.

C. Lipid

Lipid atau lemak didefinisikan sebagai biomolekul turunan hidrokarbon yang mengandung satu gugus ester.

D. Asam Nukleat

Asam nukleat adalah polimer yang tersusun dari sejumlah nukleotida. Asam nukleat makromolekul biokimia yang kompleks, berbobot molekul tinggi, dan tersusun atas rantai nukleotida yang mengandung informasi genetik.

\subsection{Unsur Penyusun Tubuh}

Dalam tubuh manusia, terdapat unsur-unsur kimia, antara lain :

A. Oksigen (65\%) dan Hidrogen (10\%, kedua unsur ini terdapat dalam air. Hampir $60 \%$ tubuh manusia terisi oleh air.

B. Karbon (18\%) merupakan unsur terbanyak kedua setelah oksigen. Unsur ini merupakan unsur yang paling stabil. 
C. Nitrogen (3\%) ditemukan dalam molekul organik, termasuk dalam asam amino sebagai pembentuk protein dan asam nukleat yang membentuk DNA.

D. Kalsium (1,5\%) adalah mineral yang paling umum di tubuh manusia, hampir semuanya ditemukan dalam tulang dan gigi.

E. Fosfor (1\%) dapat ditemukan pada bagian tulang, tetapi juga terdapat dalam molekul ATP, yang menyediakan energi dalam sel untuk menjalankan reaksi kimia.

F. Kalium (0,25\%) adalah elektrolit penting, kalium membawa muatan dalam larutan. Kalium membantu mengatur detak jantung dan sangat penting bagi sinyal listrik di saraf.

G. Sulfur (0,25\%) dapat ditemukan dalam dua asam amino.

H. Natrium $(0,15 \%)$ adalah elektrolit yang sangat vital bagi sinyal listrik di saraf. Natrium juga mengatur jumlah air dalam tubuh.

I. Klor $(0,15 \%)$ ditemukan di dalam tubuh sebagai ion negatif, yang disebut klorida. Elektrolit ini penting untuk menjaga keseimbangan cairan.

J. Magnesium $(0,05 \%)$ merupakan unsur yang mempunyai peran penting dalam struktur kerangka dan otot.

K. Besi (0,006\%) ditemukan dalam hemoglobin, yang merupakan pembawa oksigen dalam sel darah merah.

L. Fluor $(0,0037 \%)$ ditemukan pada bagian gigi dan tulang.

M. Seng (0,0032\%) adalah unsur penting bagi semua bentuk kehidupan.

N. Tembaga $(0,0001 \%)$ merupakan unsur penting sebagai donor elektron dalam reaksi biologis.

O. Yodium (0.000016\%) diperlukan untuk membuat hormon tiroid, yang mengatur tingkat metabolisme dan fungsi 
seluler lainnya. Kekurangan yodium dapat menyebabkan gondok dan kerusakan otak.

P. Selenium (0.000019\%) sangat penting untuk enzim tertentu, termasuk beberapa anti-oksidan.

Q. Kromium (0.0000024\%) membantu mengatur kadar gula dengan berinteraksi dengan insulin.

R. Mangan (0.000017\%) sangat penting untuk enzim tertentu, khususnya enzim yang melindungi mitokondria

S. Cobalt $(0.0000021 \%)$ terkandung dalam vitamin B12, berguna dalam pembentukan protein dan regulasi DNA.

\subsection{Kaitan Ilmu Biokimia Dengan Al-Quran}

Pada matakuliah biokimia dapat dipelajari reaksi-reaksi kimia dalam kehidupan dan tanda-tanda kebesaran Allah SWT, Allah berfirman dalam surat Ali-Imran ayat 190-191 : 


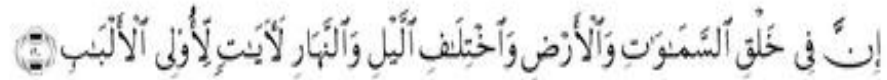

190. Sesungguhnya dalam penciptaan langit dan bumi, dan silih bergantinya malam dan siang terdapat tanda-tanda bagi orang-orang yang berakal,

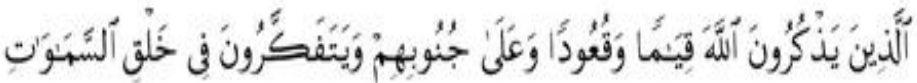

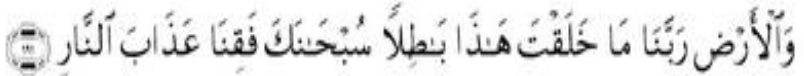

191. (yaitu) orang-orang yang mengingat Allah sambil berdiri atau duduk atau dalam keadan berbaring dan mereka memikirkan tentang penciptaan langit dan bumi (seraya berkata): "Ya Tuhan kami, tiadalah Engkau menciptakan Ini dengan sia-sia, Maha Suci Engkau, Maka peliharalah kami dari siksa neraka. 
IImu biokimia merupakan ilmu yang pokok dalam mempelajari wujud kehidupan, dari ilmu biokimia dapat dijelaskan asal-usul suatu bentuk dan sifat sel sebagai penyusun makhluk hidup. Dalam Al-Qur'an surat Al-Mu'minun ayat 13-14 dipaparkan suatu peristiwa bagaimana manusia diciptakan.

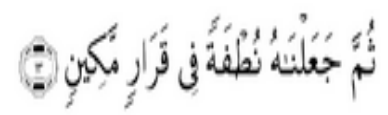

13. Kemudian kami jadikan saripati itu air mani (yang disimpan) dalam tempat yang kokoh (rahim).

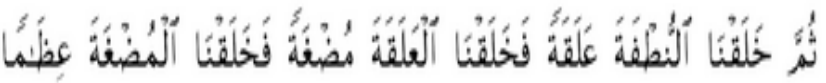

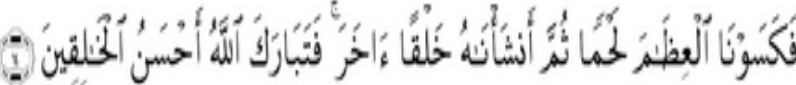

14. Kemudian air mani itu kami jadikan segumpal darah, Lalu segumpal darah itu kamm jadikan segumpal daging, dan segumpal daging itu kami jadikan tulang belulang, lalu tulang belulang itu kami bungkus dengan daging. Kenmudian kami jadikan dia maknluk yang (berbentuk) lain. Maka Maho sucilah Allah, Pencipta yans paling baik. 


\section{RANGKUMAN}

1. Awal mula penelitian biokimia terjadi pada abad XVII, Robert Hooke melakukan observasi terhadap sel-sel.

2. Istilah biokimia dikemukakan oleh Karl Neuberg, seorang ahli kimia jerman tahun 1903.

3. Biokimia berarti ilmu yang mempelajari berbagai reaksi kimia kehidupan serta interaksi molekul dalam sel makhluk hidup.

4. Tujuan mempelajari biokimia adalah untuk memahami interaksi molekul-molekul tak hidup yang menghasilkan fenomena kompleks dan efisien yang menjadi ciri-ciri kehidupan serta menjelaskan keseragaman kimia dari kehidupan yang beragam.

5. Manfaat ilmu biokimia dalam kehidupan yaitu memudahkan dalam mempelajari ilmu dasar yang berhubungan dengan makhluk hidup, dapat mengidentifikasi dan menganalisa suatu penyakit dan pengobatannya.

6. Tingkatan organisasi kehidupan dimulai dari molekul, sel, jaringan, organ, sistem organ, individu, populasi, ekosistem, hingga ke tingkatan bioma.

7. Biomolekul kompleks penyusun tubuh anatar lain karbohidrat, protein, lipid dan asam nukleat.

8. Dalam tubuh makhluk hidup terdapat bermacam-macam unsur kimia.

9. IImu biokimia dipaparkan dalam Al-Quran surat Ali-Imran ayat 190-191 dan Al-Mu'minun ayat 13-14 


\section{LATIHAN SOAL}

\section{Isilah Jawaban Dibawah ini!}

Biokimia berasal dari bahasa (1).......... yang terdiri dari (2)..... dan (3)....... organisasi terkecil yang menjadi dasar kehidupan dalam arti biologis.

(4)........ adalah unit organisasi terkecil yang menjadi dasar kehidupan dalam arti biologis. Organisme dibedakan menjadi (5) dan (6)

Penyusun protein adalah (7)...... yang dihubungan dengan ikatan (8).......

Unsur penyusun tubuh sebagai pembentuk protein dan asam nukleat yang membentuk DNA adalah (9).......

Reaksi kimia dalam kehidupan ditulis dalam surat (10)........

\section{Pilihlah Jawaban yang Benar!}

1. Istilah biokimia pertama kali dikemukakan oleh?
a. Friedrich Wohler
c. Robert Hooke
b. Karl Neuberg
d. Karl Wilhelm

2. Sekelompok atom yang saling berikatan dengan sangat kuat dalam susunan tertentu dan bermuatan netral serta cukup stabil definisi dari
a. Molekul
c. Sel
b. Atom
d. Organ

3. Biomolekul penyusun tubuh adalah
a. Lemak
c. Darah
b. Otot
d. Usus

4. Salah satu unsur penyusun tubuh adalah
a. Karbohidrat
c. Oksigen
b. Lipid
d. Asam Amino 
5. Dalam Al-Qur'an surat Al-Mu'minun ayat 13-14 dipaparkan suatu peristiwa...........

a. Reaksi-reaksi kimia dalam kehidupan

b. Asal-usul suatu bentuk dan sifat sel sebagai penyusun makhluk hidup

c. Ditemukannya proses metabolisme

d. Pertama kali Al-Quran diturunkan ke dunia

\section{Cocokan Jawaban Berikut ini!}

1. Bahwa gen terdapat pada kromosom adalah penemuan dari.......

1. Mempelajari proses kehidupan pada tingkat jaringan dan organisme merupakan hubungan antara Biokimia dengan ilmu.....

2. Polimer yang tersusun dari sejumlah nukleotida disebut

3. Penyusun tubuh pada bagian gigi dan tulang adalah....

4. Kemudian kami jadikan saripati itu air mani (yang disimpan) dalam tempat yang kokoh (rahim) termasuk dalam surat........

\section{Pilihan Jawaban :}
A. Fisiologi
B. Asam Nukleat
C. Flour
D. Al-Mu'minun ayat $13-14$
E. Gregor Mendel

\section{Benar atau Salah Pernyataan Dibawah ini!}

1. Robert Hooke ahli kimia Swedia telah melakukan penelitian mengenai susunan kimia jaringan pada tumbuhan dan hewan (B / S) 
2. Ilmu Biokimia tidak dapat untuk menganalisa perkembangan bakteri penyebab penyakit, mempelajari sifatnya dan cara pengendaliannya menggunakan bahanbahan kimia (B / S)

3. Organ adalah kumpulan dari berbagai macam jaringan dan melaksanakan suatu tugas tertentu (B / S)

4. Yodium terkandung dalam vitamin B12, berguna dalam pembentukan protein dan regulasi DNA (B / S)

5. Reaksi-reaksi kimia dalam kehidupan ditulis dalam surat Ali-Imran ayat 190-191 (B / S)

\section{Jelaskan Pertanyaan dibawah ini!}

1. Jelaskan secara singkat sejarah ilmu biokimia?

2. Jelaskan peranan Robert Hooke pada awal timbulnya ilmu biokimia?

3. Jelaskan tujuan dan manfaat mempelajari ilmu biokimia?

4. Jelaskan keterkaitan Al-Quran dalam mempelajari ilmu biokimia?

5. Bagaimana pendapat anda tentang manfaat mempelajari biokimia? 


\section{BAB II}

KARBOHIDRAT

\begin{tabular}{|c|c|}
\hline Tujuan Instruksional & Materi \\
\hline $\begin{array}{l}\text { Mahasiswa memahami } \\
\text { tentang pengertian } \\
\text { karbohidrat sehingga } \\
\text { dapat diterapkan dalam } \\
\text { bidang kesehatan sesuai } \\
\text { dengan perkembangan } \\
\text { sains dan teknologi. }\end{array}$ & $\begin{array}{l}\text { 2.1 Pendahuluan } \\
\text { 2.2 Fungsi Karbohidrat } \\
\text { 2.3 Klasifkasi Karbohidrat } \\
\text { 2.4 Penyakit yang berhubungan } \\
\text { dengan Karbohidrat } \\
\text { 2.5 Identifikasi Karbohidrat }\end{array}$ \\
\hline
\end{tabular}

\subsection{Pendahuluan}

Dalam melakukan aktivitasnya makhluk hidup memerlukan energi yang diperoleh dari bahan makanan. Salah satu makromolekul yang terdapat pada bahan makanan yaitu karbohidrat. Energi yang terkandung dalam karbohidrat berasal dari energi matahari. Pembentukan karbohidrat dalam hal ini glukosa dibentuk dari karbon dioksida dan air dengan bantuan sinar matahari dan klorofil dalam daun melalui proses fotosintesis. Karbohidrat banyak terdapat pada beras, jagung, sagu, singkong dan gula. Selain itu, terdapat juga karbohidrat yang tidak dapat dicerna seperti kayu dan serat kapas karena pada tumbuhan tersebut mengandung selulosa.

Sakarida adalah nama lain dari karbohidrat dan berasal dari bahasa Arab "sakkar" yang berarti gula. Karbohidrat merupakan suatu senyawa organik polihidroksialdehid atau polihidroksiketon. Rumus umum dari karbohidrat adalah $\mathrm{C}_{n}\left(\mathrm{H}_{2} \mathrm{O}\right)_{n}$ atau $\mathrm{C}_{n} \mathrm{H}_{2 n} \mathrm{O}_{n}$. Karbohidrat terdiri dari unsur karbon, hidrogen, dan oksigen. Contoh : glukosa $\mathrm{C}_{6} \mathrm{H}_{12} \mathrm{O}_{6}$, sukrosa $\mathrm{C}_{12} \mathrm{H}_{22} \mathrm{O}_{11}$, selulosa $\left(\mathrm{C}_{6} \mathrm{H}_{10} \mathrm{O}_{5}\right) \mathrm{n}$. 


\subsection{Fungsi Karbohidrat}

A. Sumber Energi utama tubuh

Fungsi karbohidratyang utama sebagai pasokan energi tubuh, setiap gram karbohidrat mengandung 4 kalori. Binatang menyusui (mamalia) dapat mengubah sukrosa, laktosa (gula susu), maltosa dan pati menjadi glukosa yang kemudian digunakan sebagai energi atau disimpan sebagai glikogen. Karbohidrat yang diubahmenjadi glikogen dan lemak disimpan didalam jaringan otot berfungsi sebagai cadangan energi tubuh. Karbohidrat dapat juga diubah menjadi steroid dan secara terbatas diubah menjadi protein.

B. Memperlancar pencernaan

Karbohidrat yang dapat dicerna berfungsi untuk memperlancar peristaltik usus dan memudahkan pembuangan feses. Contoh karbohidrat yang dapat dicerna adalah karbohidrat golongan monokasarida dan disakarida. Selain itu karbohidrat yang tidak dapat dicerna seperti serat bisa memberikan rasa kenyang.

C. Sebagai pemanis alami

Karbohidrat juga berfungsi sebagai pemberi rasa manis alami pada makanan khususnya karbohidrat golongan monokasarida dan disakarida.

\subsection{Klasifikasi karbohidrat}

Karbohidrat digolongkan menjadi 4 klasifikasi yaitu:

\section{A. Monosakarida}

Monosakarida adalah karbohidrat yang tidak dapat dihidrolisis menjadi senyawa yang lebih sederhana karena molekulnya hanya terdiri dari beberapa atom C. Monosakarida sering disebut gula sederhana. Monosakarida 
dapat diikat secara bersama-sama untuk membentuk dimer, trimer dan sebagainya. Dimer adalah senyawa kimia yang terdiri dari dua molekul yang identik atau mirip dan terikat bersama-sama.

Monosakarida dibedakan menjadi aldosa (mempunyai gugus aldehida) dan ketosa (mempunyai gugus keton). Akhiran -osa digunakan dalam tata nama karbohidrat untuk menyatakan suatu gula pereduksi (suatu gula yang mengandung gugus aldehida atau gugus $\alpha$-hidroksiketon). Contoh dari aldoheksosa yaitu glukosa dan galaktosa, sedangkan contoh ketoheksosa yaitu fruktosa. Monosakarida larut dalam air dan umumnya terasa manis.

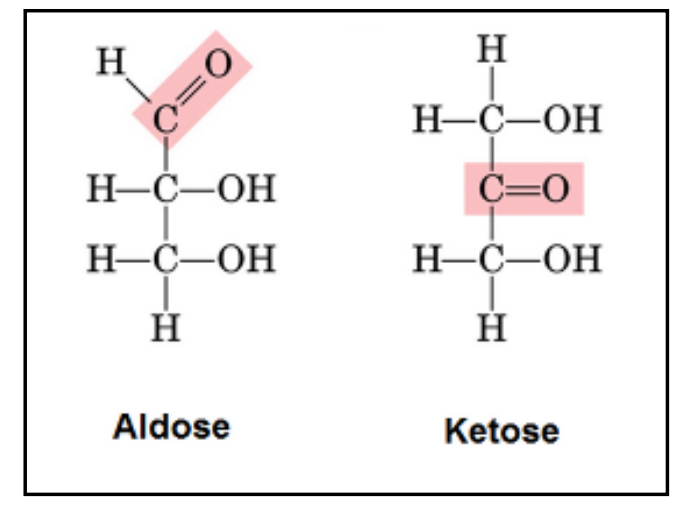

Gambar 2.1 Struktur Aldosa dan Ketosa (Fessenden,1986)

Monosakarida disusun oleh 3 sampai 7 atom karbon, dan jumlah atom penyusunnya mempengaruhi penamaan masing-masing monosakarida, yaitu:

1. Triosa (tersusun atas 3 atom $\mathrm{C}$ )

Monosakarida yang termasuk triosa yaitu gliseraldehida dan dihidroksiaseton. Gliseraldehida disebut juga 
aldotriosa karena mempunyai gugus aldehida sedangkan dihidroksiaseton disebut juga ketotriosa karena mempunyai gugus keton.

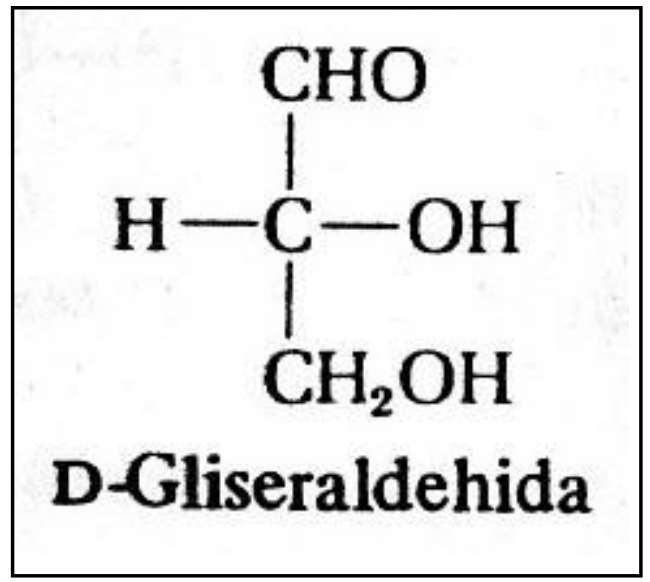

Gambar 2.2 Struktur Gliseraldehida (Fessenden,1986)

2. Tetrosa (tersusun atas 4 atom $\mathrm{C}$ )

Monosakarida yang termasuk tetrosa yaitu eritrosa dan eritrulosa. Eritrosa contoh dari aldotetrosa sedangkan eritrulosa contoh dari ketotetrosa.

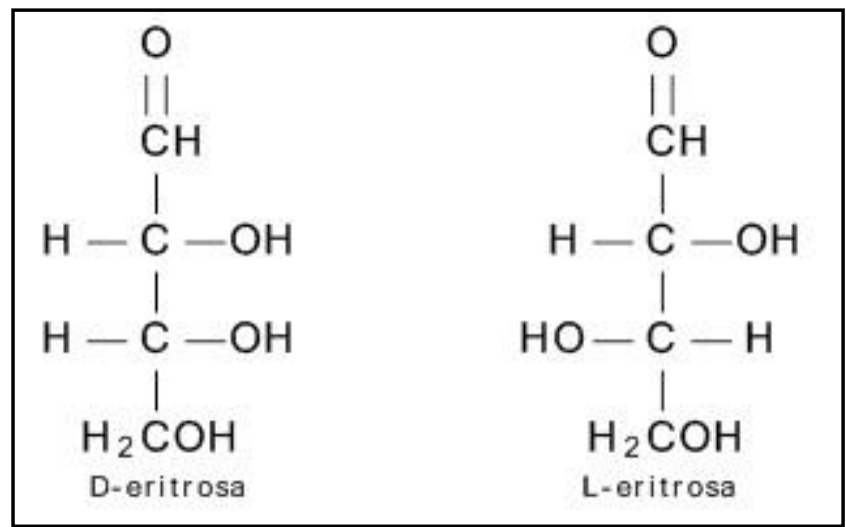

Gambar 2.3 Struktur Eritrosa (Fessenden,1986) 
3. Pentosa (tersusun atas 5 atom $\mathrm{C}$ )

Monosakarida yang termasuk pentosa yaitu ribosa dan ribulosa. Ribosa adalah suatu aldopentosa sedangkan ribulosa adalah suatu ketopentosa. Pentosa merupakan monosakarida yang penting dalam kehidupan. Beberapa pentosa yang tidak terdapat di alam bebas dan termasuk aldopentosa yaitu arabinosa, xilosa, ribosa dan 2deoksiribosa. Arabinosa diperoleh dari proses hidrolisis gom arab. Xilosa diperoleh dari proses hidrolisis jerami atau kayu. Ribosa dan deoksiribosa merupakan komponen dari asam nukleat.

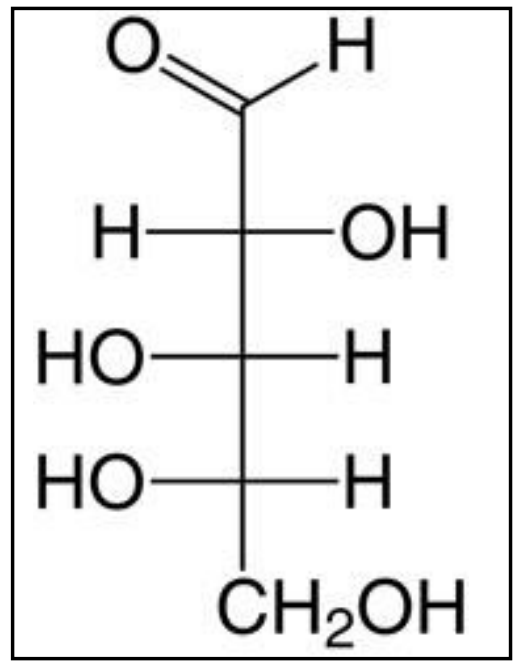

Gambar 2.4 Struktur Arabinosa (Fessenden,1986)

4. Heksosa (tersusun atas 6 atom C)

Monosakarida yang termasuk heksosa yaitu glukosa, galaktosa dan fruktosa. Glukosa salah satu monosakarida yang penting, kadang-kadang disebut gula darah karena terdapat dalam darah, gula anggur karena terdapat dalam buah anggur. Glukosa 
terdapat dalam buah-buahan dan madu. Pada keadaan normal, konsentrasi glukosa dalam darah antara 70-100 mg tiap $100 \mathrm{ml}$ darah. Pada penderita diabetes militus konsentrasi glukosa dalam darah lebih besar dari $130 \mathrm{mg}$ per $100 \mathrm{ml}$ darah.

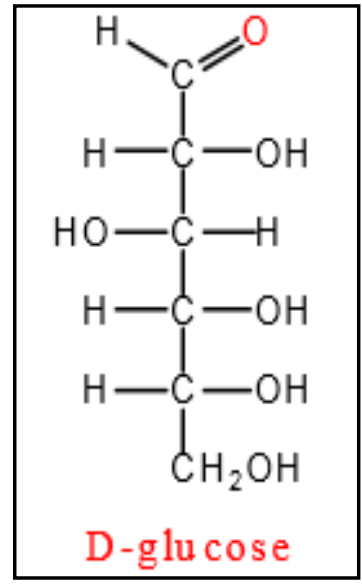

Gambar 2.5 D-Glukosa (Harper, 1980)

Galaktosa jarang ditemui di alam bebas, biasanya galaktosa berikatan dengan glukosa dalam bentuk laktosa.

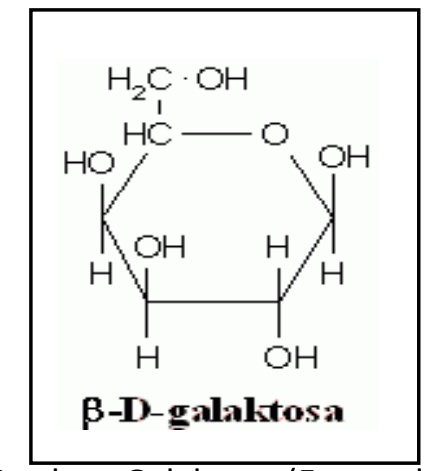

Gambar 2.6 Struktur Galaktosa (Fessenden,1986) 
Fruktosa disebut terdapat dalam madu lebah, fruktosa mempunyai rasa lebih manis daripada glukosa dan sukrosa.

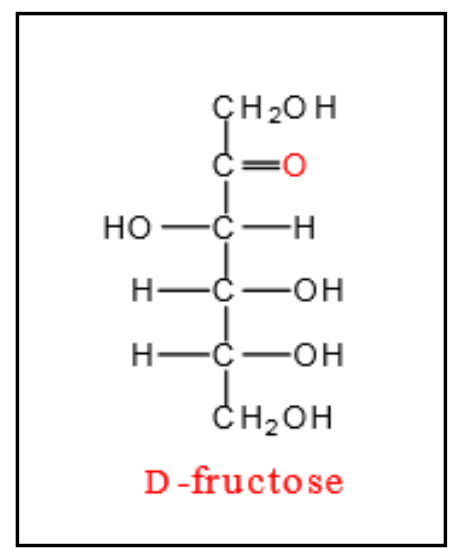

Gambar 2.7 D-fruktosa (Harper, 1980)

5. Heptosa (tersusun atas 7 atom C)

\section{HEPTOSA}

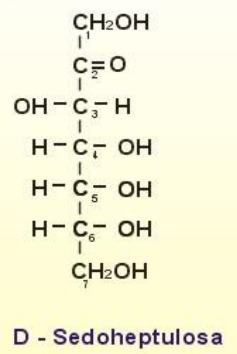

Gambar 2.8 Struktur Sedoheptulosa (Harper, 1980) 


\section{B. Disakarida}

Disakarida adalah karbohidrat yang terdiri atas 2 unit gula atau 2 molekul monosakarida. Ikatan antara dua molekul monosakarida disebut ikatan glikosidik. Ikatan glikosidik terbentuk dari gugus hidroksil atom $\mathrm{C}$ nomor 1 yang juga disebut karbon numerik dengan gugus hidroksil pada molekul gula yang lain. Disakarida larut dalam air dan umumnya terasa manis.

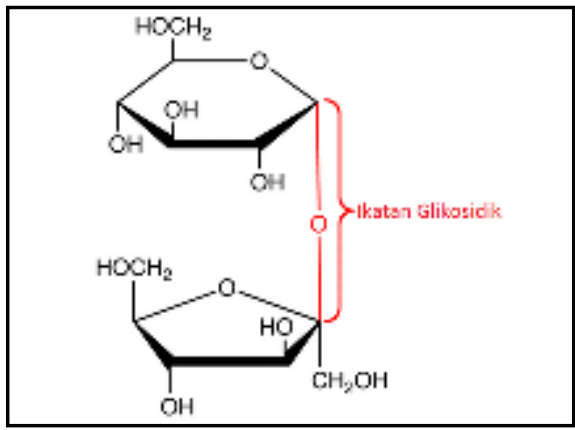

Gambar 2.9 Ikatan Glikosidik pada sukrosa menggabungkan glukosa dan fruktosa (Fessenden,1986)

Disakarida dibedakan menjadi dua macam yaitu

1. Disakarida dengan gugus hemiasetal bebas merupakan senyawa dengan satu unit glikosil yang dapat digantikan dengan atom hidrogen dari gugus hidroksi alkoholik dari unit lainnya sehingga mempunyai gugus -OH glikosidik dan bersifat mereduksi, contohnya adalah maltosa dan laktosa

2. Disakarida tanpa gugus hemiasetal bebas merupakan senyawa yang dibentuk dengan reaksi dua glikosidik gugus hidroksi dengan gugus yang lainnya sehingga tidak mempunyai gugus - $\mathrm{OH}$ glikosidik dan bersifat tidak dapat mereduksi, contohnya adalah sukrosa. 
Disakarida yang sangat penting antara lain :

a. Sukrosa

Sukrosa merupakan gula yang berasal dari tebu, bit, madu lebah, buah nanas dan wortel. Hasil hidrolisis sukrosa yaitu glukosa dan fruktosa. Ikatan glukosa dan sukrosa terjadi antara atom karbon nomor 1 pada glukosa dengan atom karbon nomor 2 pada fruktosa sehingga sukrosa tidak mempunyai gugus aldehida atau keton bebas atau tidak mempunyai gugus - $\mathrm{OH}$ glikosidik dan bersifat tidak dapat mereduksi ion $\mathrm{Cu}^{2+}$ atau $\mathrm{Ag}^{+}$dan tidak membentuk osazon. Sukrosa mempunyai rasa lebih manis dibandingkan maltosa.

Gula inversi adalah campura D-glukosa dan D-fruktosa yang diperoleh dengan hidrolisis asam atau enzimatik dari sukrosa. Enzime yang mengkatalisis hidrolisis sukrosa, disebut invertase, bersifat spesifik untuk ikatan $\beta$-Dfruktofuranosida dan terdapat dalam ragi dan lebah. Nama gula inversi diturunkan dari inversi (pembalikan) tanda rotasi jenis bila sukrosa dihidrolisis. Sukrosa mempunyai rotasi jenis $+66,5^{\circ}$ (rotasi positif). Campuran produk (glukosa, $[\alpha]=+52,7^{\circ}$ dan fruktosa, $[\alpha]=-92,4^{\circ}$ ) mempunyai rotasi netto negatif.

Adanya fruktosa bebas maka gula inversi lebih manis daripada sukrosa. Suatu gula inversi sintetik yang disebut isomerase dibuat dengan isomerisasi enzimatik dari glukosa dalam sirup jagung, penggunaan komersial gula inversi sintetik adalah untuk pembuatan es krim, minuman ringan dan permen. 


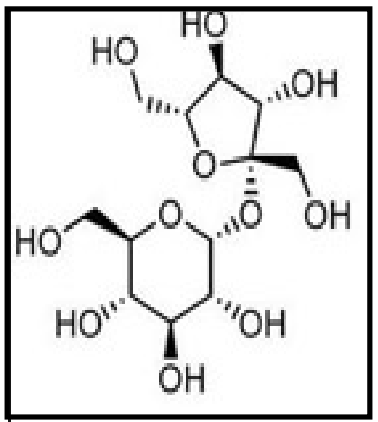

Gambar 2.10 Struktur Sukrosa (Fessenden,1986)

b. Maltosa

Maltosa adalah disakarida yang terbentuk dari dua molekul glukosa. Ikatan dua molekul glukosa terjadi antara atom karbon nomor 1 pada glukosa pertama dan atom karbon nomor 4 pada glukosa kedua sehingga maltosa mempunyai gugus $\mathrm{OH}$ glikosidik dan bersifat mereduksi. Maltosa mudah larut dalam air dan mempunyai rasa lebih manis daripada laktosa. Maltosa digunakan dalam makanan bayi dan susu bubuk beragi (malted milk). Maltosa diperoleh dari hidrolisis pati.

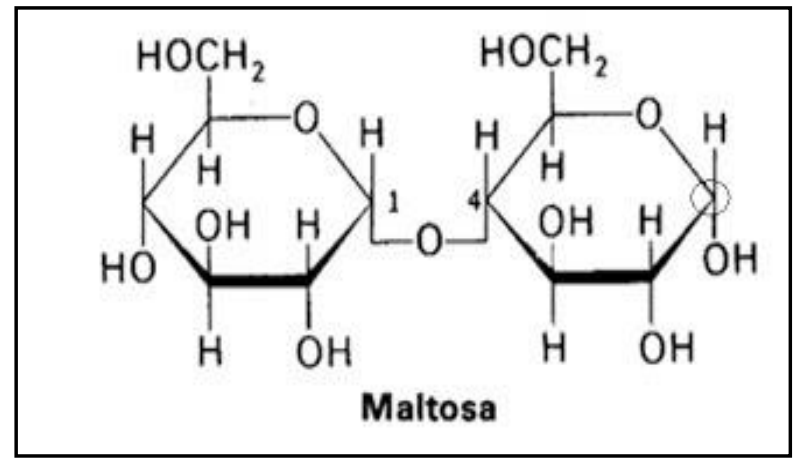

Gambar 2.11 Struktur Maltosa (Fessenden, 1986) 
c. Laktosa.

Hasil hidrolisis laktosa yaitu D-galaktosa dan Dglukosa. Ikatan galaktosa dan glukosa terjadi antara atom karbon nomor 1 pada galaktosa dan atom karbon nomor 4 pada glukosa sehingga laktosa mempunyai gugus $\mathrm{OH}$ glikosidik dan bersifat mereduksi. Laktosa disebut juga gula susu.

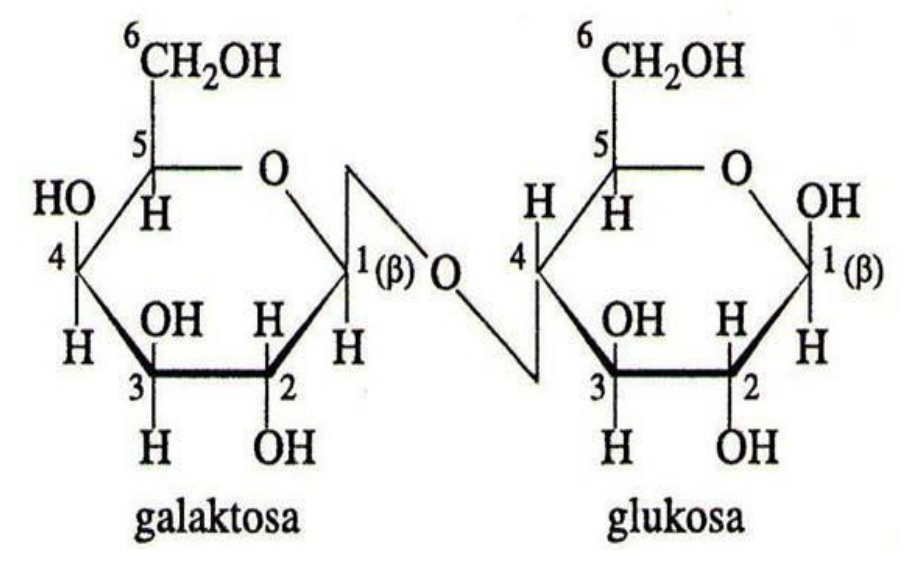

Gambar 2.12 Struktur Laktosa (Fessenden,1986)

\section{Oligosakarida}

Oligosakarida adalah karbohidrat yang terdiri atas 310 unit monosakarida dan digabungkan dengan ikatan kovalen. Contoh oligosakarida adalah rafinosa dan stakiosa.

1. Rafinosa

Rafinosa terdiri dari 3 monosakarida yaitu galaktosaglukosa-fruktosa. Atom karbon nomor 1 pada galaktosa berikatan dengan atom karbon nomor 6 pada glukosa kemudian atom karbon nomor 1 pada glukosa berikatan dengan atom karbon nomor 2 pada fruktosa sehingga 
rafinosa tidak mempunyai gugus - $\mathrm{OH}$ glikosidik dan bersifat tidak mereduksi. Rafinosa terdapat pada bit dan tepung biji kapas.

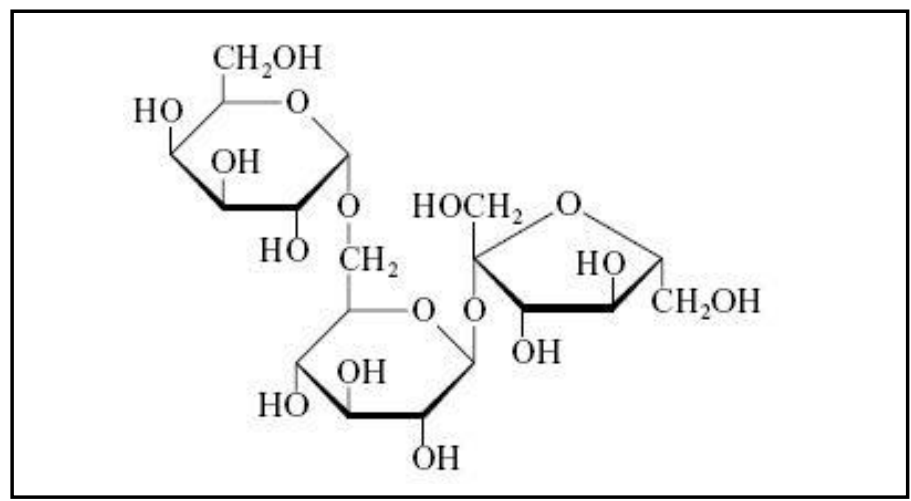

Gambar 2.13 Struktur Rafinosa (Fessenden,1986)

2. Stakiosa terdiri dari 4 monosakarida yaitu 2 galaktosa, 1 glukosa dan 1 fruktosa. Stakiosa tidak bersifat mereduksi.

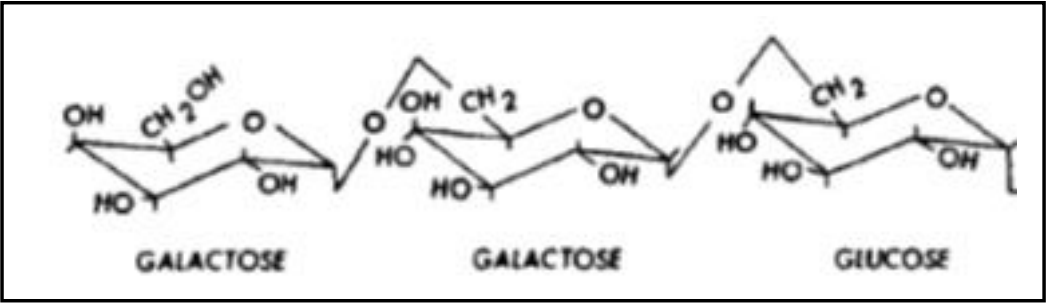

Gambar 2.14 Struktur Stakiosa (Fessenden,1986)

\section{Polisakarida}

Polisakarida adalah karbohidrat yang mempunyai lebih dari 10 unit monosakarida dan diperoleh dari hidrolisis. Polisakarida yang terdiri atas satu macam monosakarida disebut homopolisakarida, sedangakan 
polisakarida yang mengandung senyawa lain disebut heteropolisakarida. Polisakarida mempunyai tiga maksud dalam sistem kehidupan yaitu sebagai bahan pembangun, bahan makanan/nutrisi, dan sebagai zat spesifik.

Contoh polisakarida sebagai bahan pembangun adalah selulosa, yang memberikan kekuatan pada pokok kayu dan dahan bagi tumbuhan; dan kitin, komponen struktur dari kerangka luar serangga. Contoh polisakarida bahan nutrisi adalah pati dan glikogen. Contoh polisakarida zat spesifik adalah heparin. Polisakarida yang sangat penting antara lain :

1. Pati

Pati merupakan polisakarida paling melimpah kedua. Nama lain pati adalah amilum. Pati terdapat pada gandum, tepung jagung, umbi, daun, batang dan biji-bijian. Pati dapat dipisahkan menjadi dua fraksi utama berdasarkan kelarutan dalam air panas, sekitar $20 \%$ pati adalah amilosa yang larut dalam air panas dan $80 \%$ adalah amilopektin yang tidak larut air panas. Amilosa terdiri atas 250-300 unit glukosa yang terikat dengan ikatan $\alpha$ 1,4-glikosidik. Amilopektin terdiri atas lebih dari 1000 unit glukosa yang mempunyai ikatan 1,4-glikosidik dan 1,6-glikosidik.

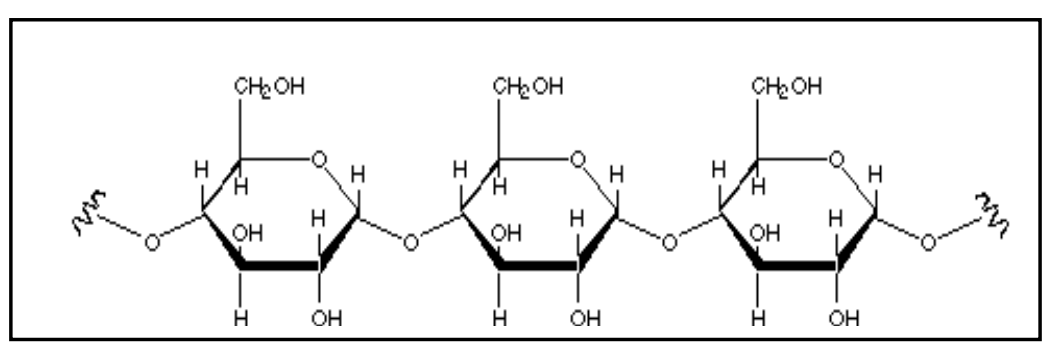

Gambar 2.15 Struktur Amilosa (Fessenden,1986) 


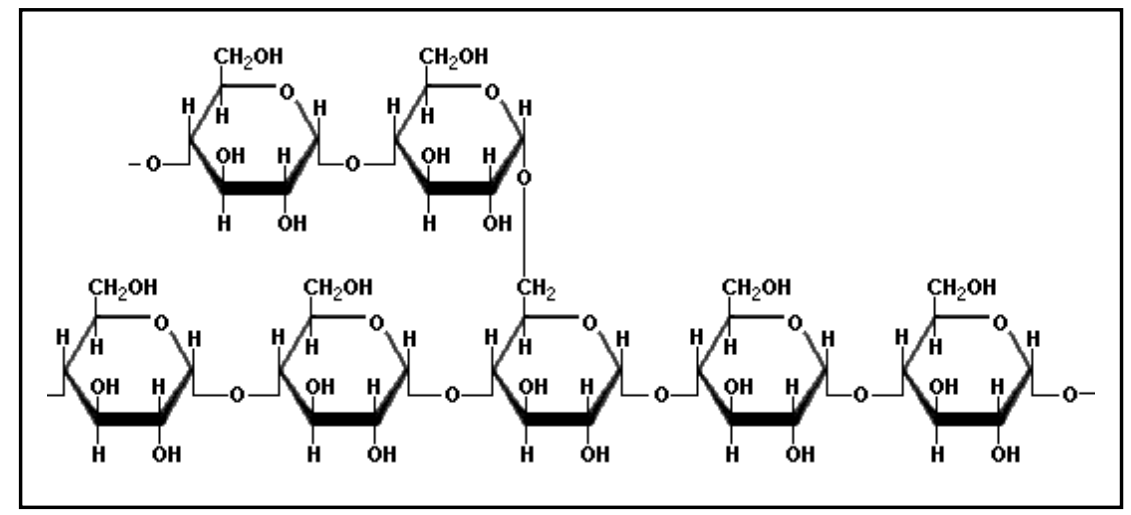

Gambar 2.16 Struktur Amilopektin (Fessenden,1986)

2. Glikogen

Di Alam glikogen ditemukan pada kerang, alga atau rumput laut. Struktur glikogen serupa dengan struktur amilopektin yaitu terdiri atas lebih dari 1000 unit glukosa yang mempunyai ikatan 1,4-glikosidik dan 1,6-glikosidik. Glikogen lebih bercabang daripada amilopektin. Glikogen terdapat dalam hati dan otot. Pembentukan glikogen dari glukosa terjadi di hati. Glikogen pada otot digunakan sebagai sumber energi untuk melakukan aktivitas seharihari.

Apabila kadar glukosa dalam darah bertambah, sebagian diubah menjadi glikogen sehingga kadara glukosa dalam darah normal kembali, sebaliknya apabila kadar glukosa dalam darah menurun, glikogen dalam hati diuraikan menjadi glukosa kembali sehingga kadar glukosa darah normal kembali. 


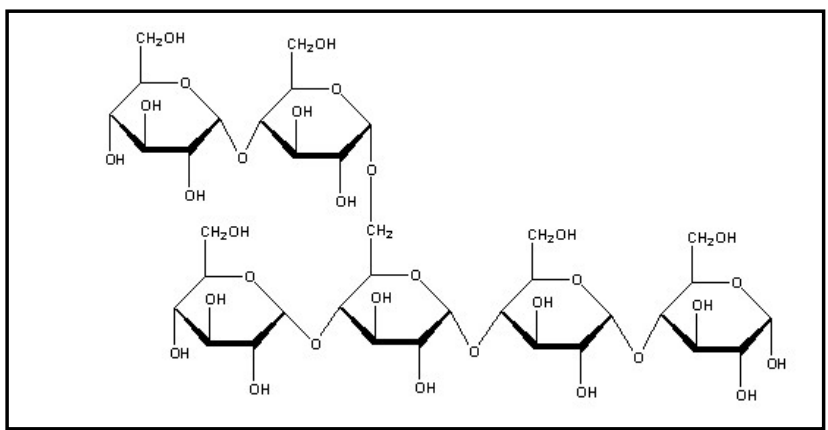

Gambar 2.17 Struktur Glikogen (Fessenden,1986)

\section{Dekstrin}

Larutan dekstrin dimanfaatkan sebagai bahan perekat. Dekstrin merupakan hasil antara pada proses hidrolisis amilum sebelum terbentuk maltosa. Tahapan hidrolisis amilum:

Amilum $\rightarrow$ amilum terlarut $\rightarrow$ amilodekstrin $\rightarrow$ eritrodekstrin $\rightarrow$ akrodekstrin $\rightarrow$ maltosa

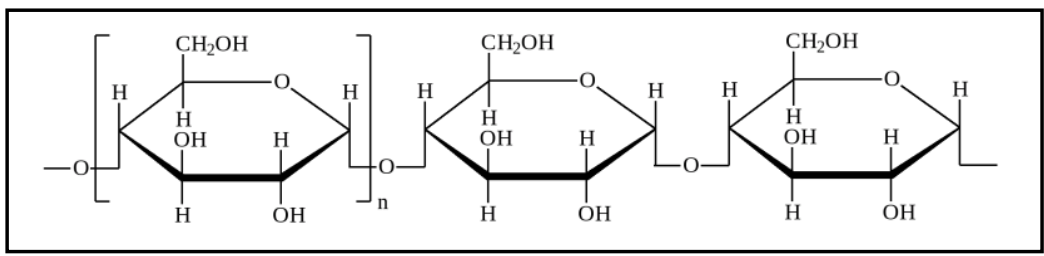

Gambar 2.18 Struktur Dekstrin (Fessenden,1986)

\section{Selulosa}

Selulosa terdapat pada tumbuhan digunakan sebagai bahan pembentukan dinding sel. Pada manusia selulosa tidak dapat dicerna karena tidak mempunyai enzim yang dapat menguraikan selulosa. Selulosa penyusun yang bersifat serat dari tumbuhan dan komponen utama dari 
kapas. Selulosa berguna untuk memperlancar pencernaan makanan.

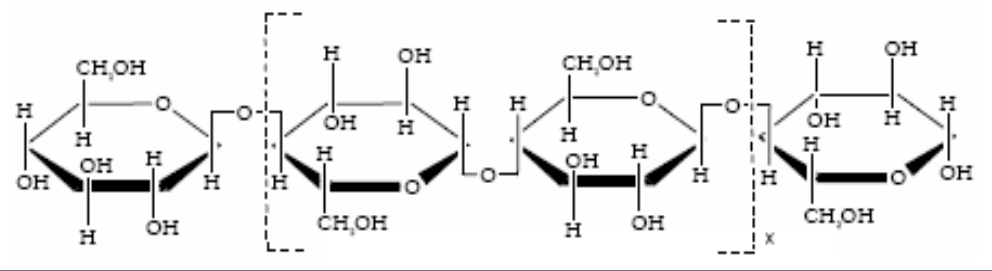

Gambar 2.19 Struktur Selulosa (Fessenden,1986)

Selobiosa adalah suatu disakarida yang terdiri atas dua molekul glukosa yang berikatan glikosidik antara atom karbon nomor 1 dengan atom karbon nomor 4 .

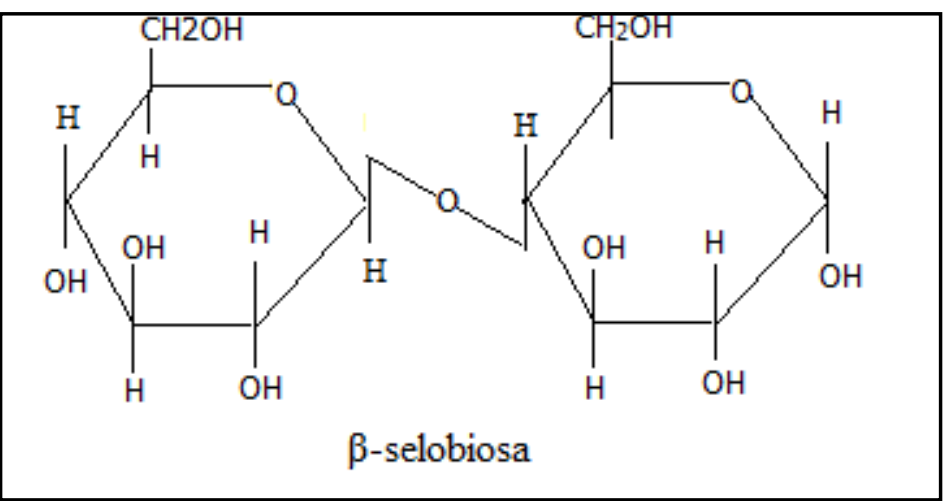

Gambar 2.20 Struktur Selobiosa (Fessenden,1986)

5. Asam Hialuronat

Asam Hialuronat termasuk heteropolisakarida yang terdapat pada otot. Asam Hialuronat terbentuk dari Nasetilglukosamina dan asam glukuronat. 
6. Heparin

Heparin merupakan senyawa yang berfungsi sebagai antikoagulan darah (mencegah koagulasi darah). Heparin salah satu contoh heteropolisakarida.

7. Kitin

Kitin merupakan polisakarida sebagai bahan pembangun bagi hewan yang mempunyai kaki banyak. Kitin mengandung polisakarida linier $\mathrm{N}$-asetil-D-glukosamina terikat - $\beta$. Pada hidrolisis, kitin menghasilkan 2-amino-2deoksi-D-glukosa. Di alam kitin berikatan pada protein dan lipid.

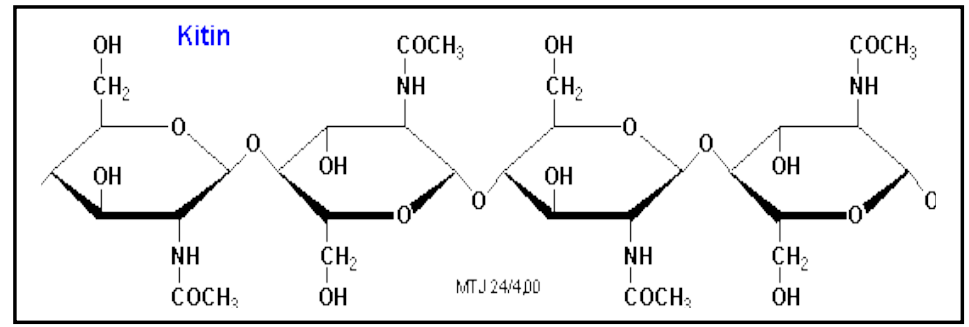

Gambar 2.21 Struktur Kitin (Fessenden,1986)

\subsection{Penyakit-penyakit yang berhubungan dengan Karbohidrat}

A. Obesitas : Kelebihan berat badan akibat kelebihan kalori / kelebihan karbohidrat

B. Marasmus : Suatu kondisi serius malnutrisi kekurangan kalori dan protein.

C. Diabetes Militus : Gangguan Metabolisme Karbohidrat

D. Laktose intolerance : gangguanmetabolisme laktosa karena difisiensi enzim laktase. 


\subsection{Identifikasi Karbohidrat}

\section{A. Uji Umum Identifikasi Karbohidrat}

1. Uji Molisch

Prinsip : kondensasi dari hidroksi metal furfural (heksosa) atau furfural (pentosa) dengan alfa-naftol membentuk suatu cincin berwarna ungu.

Alfa-naftol berfungsi sebagai indikator warna untuk memudahkan saja, sedangkan $\mathrm{H}_{2} \mathrm{SO}_{4}$ berfungsi untuk menghidrolisis glukosa (heksosa) $\rightarrow$ hidroksimetil fufural atau arabinosa (pentosa) $\rightarrow$ furufural. Reaksi Molisch ini positif untuk semua karbohidrat.

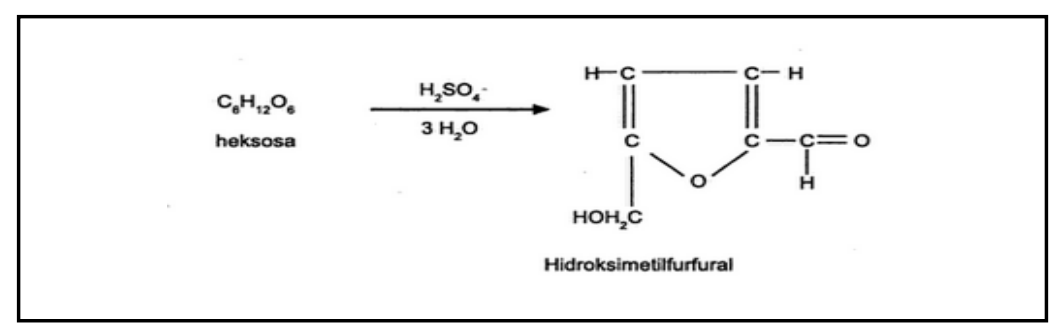

Gambar 2.22 Reaksi Dehidrasi Heksosa (Fessenden,1986)

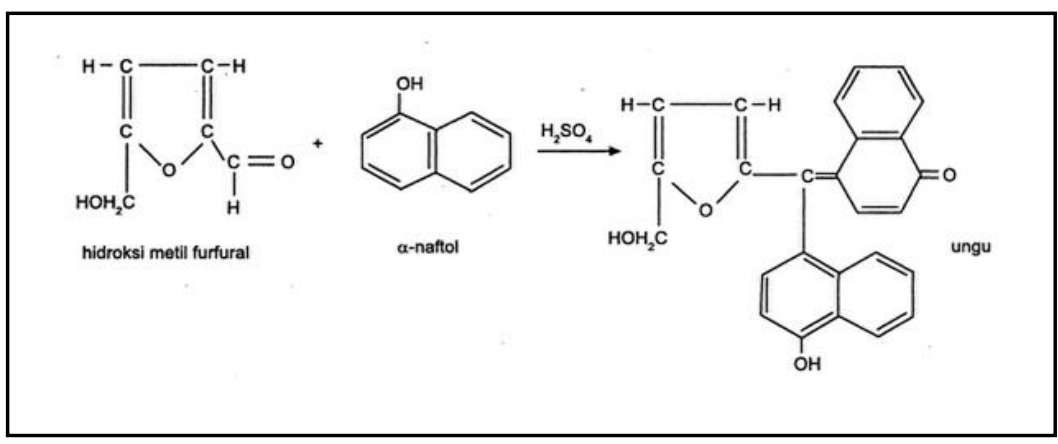

Gambar 2.23 Reaksi Kondensasi Hidroksimetilfurfural dengan Alfanaftol (Fessenden,1986) 
2. Uji Anthron

Prinsip : Tiga tahapan reaksi untuk polisakarida atau disakarida dan dua tahapan reaksi untuk monosakarida (heksosa atau pentosa). Hidroksimetilfurfural atau furfural yang terbentuk karena kerja asam sulfat pekat berkondensasi dengan Anthron membentuk senyawa kompleks yang berwarna.

Larutan 0,2\% Anthron dalam asam sulfat pekat ditambah larutan karbohidrat, setelah didiamkan akan terbentuk warna hijau atau hijau kebiruan.

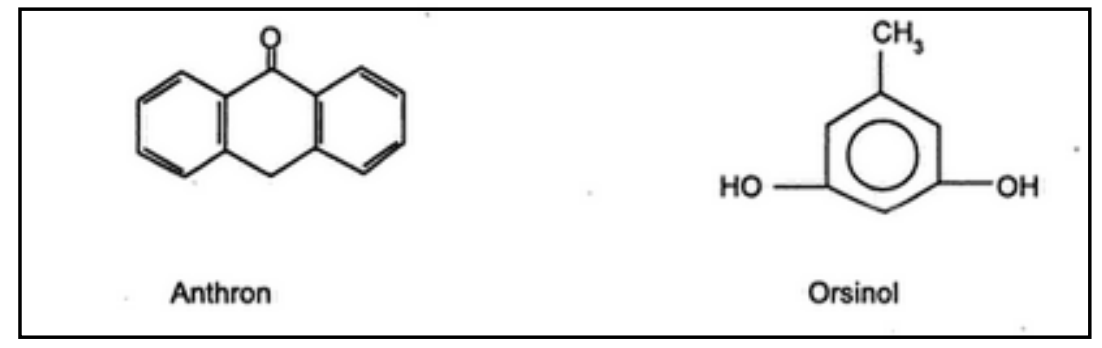

Gambar 2.24 Uji Anthron (Fessenden,1986)

3. Percobaan lod

Amilum ditetesi lod, maka molekul lod akan terperangkap di dalamnya. Akibatnya larutan ini akan berwarna biru. Ketika dipanaskan, amilum akan terhidrolisis menjadi monosakarida sehingga lod bias terlepas. Selanjutnya ditambahkan $\mathrm{NaOH}$ maka I- akan bereaksi dengan $\mathrm{Na}+$ membentuk $\mathrm{Nal}$, akibatnya larutan akan menjadi bening. Hal ini tidak berlaku untuk jenis-jenis sakarida yang lain seperti monosakarida, disakarida, dan oligosakarida karena struktur mereka masih sederhana. 
4. Reaksi Fenilhidrazin (pembentukan osazon)

Fenilhidrazin bereaksi dengan monosakarida dan beberapa disakarida membentuk hidrazon dan osazon. Hidrazon merupakan substansi yang mudah larut (soluble) dan sulit diisolasi. Sedang osazon kebalikannya, ia relatif tidak melarut dan membentuk kristal yang bentuknya spesifik untuk setiap jenis sakarida. Itulah sebabnya mengapa osazon menjadi begitu penting dalam membantu mengidentifikasi konfigurasi struktural dari sakarida. Sukrosa tidak membentuk osazon. Reaksi pembentukan osazon adalah sebagai berikut:

Aldosa + fenilhidrazin $\rightarrow$ fenilhidrazon

Fenilhidrazon +2 fenilhidrazin $\rightarrow$ Osazon + aniline $+\mathrm{NH}_{3}$ $+\mathrm{H}_{2} \mathrm{O}$

5. Sukrosa

Pada sukrosa, $\mathrm{HCl}$ akan menghidrolisis sukrosa menjadi glukosa dan fruktosa. Akan tetapi karena kereaktifan antara glukosa dan fruktosa. Akan tetapi karena kereaktifan antara glukosa dan fruktisa terhadap $\mathrm{HCl}$ encer berbeda maka fruktosa akan lebih dahulu membentuk suatu senyawa hidroksimetil furfural yang kemudian akan bereaksi dengan resorsinol membentuk kompleks berwarna merah.

\section{Maltosa}

Maltosa bila dihidrolisis akan menghasilkan 2 molekul glukosa yang kurang reaktif terhadap terhadap $\mathrm{HCl}$ encer, sehingga memberi efek yang negatif terhadap resorsinol. 


\section{Galaktosa}

Identifikasi galaktosa dapat dilakukan dengan cara oksidasi oleh asam nitrat pekat dan dalam keadaan panas, sehingga galaktosa menghasilkan asam musat. Asam musat mudah dimurnikan dan diketahui bentuk kristal dan titik leburnya.

\section{Fruktosa}

Identifikasi fruktosa dengan pereaksi Seliwanoff, yaitu larutan resorsinol (1,3 dihidroksi-benzena) dalam asam $\mathrm{HCl}$. Mula-mula fruktosa diubah menjadi hidroksimetilfurfural lalu bereaksi dengan resorsinol membentuk senyawa berwarna merah.

9. Laktosa

Jika laktosa dihidrolisis kemudian dipanaskan dengan asam nitrat akan terbentuk asam musat.

10. Rafinosa

Hidrolisis rafinosa dengan asam lemah dengan bantuan enzim sukrase akan menghasilkan melibiosa dan fruktosa. Hidrolisis rafinosa dengan bantuan enzim maltase akan menghasilkan galaktosa dan sukrosa. Apabila dua enzim yaitu enzim sukrase dan enzim melibiase digunakan bersamaan akan menguraikan melibiosa menjadi galaktosa dan glukosa.

\section{Amilum}

Butir-butir amilum tidak larut dalam air dingin tetapi apabila suspensi dalam air dipanaskan, akan terjadi suatu larutan koloid yang kental. Apabila larutan koloid ditetesi 
larutan iodium akan menghasilkan larutan berwarna biru. Warna biru disebabkan oleh molekul amilosa yang membentuk senyawa. Amilopektin bila bereaksi dengan iodium akan memberikan warna ungu atau merah lembayung.

Amilum dapat dihidrolisis sempurna dengan menggunakan asam sehingga menghasilkan glukosa. Enzim amilase mengubah amilum menjadi maltosa.

\section{Glikogen}

Glikogen dihidrolisis menghasilkan glukosa. Glikogen yang larut dalam air akan diendapkan dengan penambahan etanol lalu endapan yang terbentuk bila dikeringkan akan berbentuk serbuk putih. Reaksi antara glikogen dengan iodium akan menghasilkan warna merah.

\section{Selulosa}

Selulosa tidak dapat dihidrolisis dengan asam encer, tetapi dapat dihidrolisis dengan asam konsentrasi tinggi menjadi selobiosa dan glukosa.

\section{B. Uji Khusus Karbohidrat Pereduksi}

1. Uji Fehling

Prinsip : Gugus aldehida dan keton bebas dalam molekul karbohidrat dapat mereduksi $\mathrm{Cu}^{2+}$ yang terdapat dalam pereaksi Fehling menjadi $\mathrm{Cu}^{+}$berupa endapan merah $\mathrm{Cu}_{2} \mathrm{O}$

Pereaksi Fehling ditambahkan karbohidrat pereduksi, kemudian dipanaskan, akan terjadi perubahan warna dari biru $\rightarrow$ hijau $\rightarrow$ kuning $\rightarrow$ kemerah-merahan dan akhirnya terbentuk endapan merah bata kupro oksida bila jumlah 
karbohidrat pereduksi banyak. Pada reaksi ini, Karbohidrat pereduksi akan diubah menjadi asam onat yang membentuk garam karena adanya basa, sedangkan pereaksi fehling akan mengalami reduksi sehingga $\mathrm{Cu}^{2+}$ diubah menjadi $\mathrm{Cu}^{+}$.

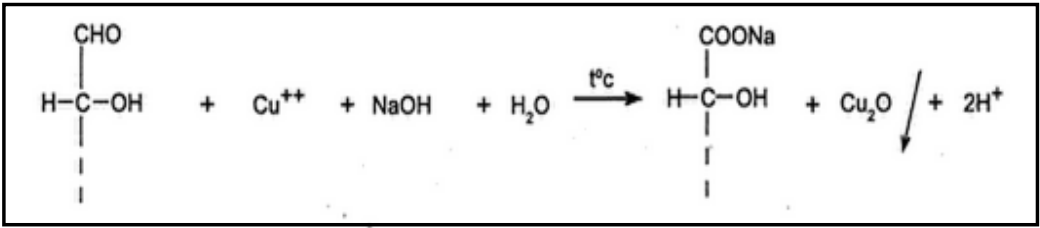

Gambar 2.25 Reaksi Karbohidrat Pereduksi dengan Pereaksi Fehling (Fessenden,1986)

2. Uji Benedict

Reaksi ini spesifik untuk karbohidrat yang mempunyai gugus karbonil bebas, yaitu semua monosakarida dan disakarida kecuali sukrosa dan trehalosa. Reaksi yang terjadi adalah reduksi-oksidasi. Reagen yang digunakan dalam reaksi benedict antara lain :

a. $\mathrm{CuSO}_{4}$ berfungsi sebagai penyedia ion $\mathrm{Cu}^{2+}$

b...Na-sitrat berfungsi sebagai penghambat terjadinya endapan $\mathrm{Cu}(\mathrm{OH})_{2}$ atauCuCO${ }_{3}$

c. $\mathrm{Na}_{2} \mathrm{CO}_{3}$ berfungsi sebagai alkali yang mengubah gugus karbonil bebas dari gula menjadi bentuk enol yang reaktif. Enol yang reaktif mereduksi $\mathrm{Cu}^{2+}$ dari senyawa kompleks dengan sitrat menjadi $\mathrm{Cu}^{+}$. $\mathrm{Cu}^{+}$bersama $\mathrm{OH}$ membentuk $\mathrm{CuOH}$ (berwarna kuning), yang dengan pemanasan akan berubah menjadi endapan $\mathrm{Cu}_{2} \mathrm{O}$ yang berwarna merah. Warna yang terbentuk bervariasi mulai dari hijau, kuning, orange, merah sampai endapan merah bata, tergantung jumlah $\mathrm{Cu}_{2} \mathrm{O}$ yang terbentuk, sehingga 
reaksi ini dapat digunakan untuk menentukan adanya gula baik secara kualitatif maupun kuantitatif.

$\left[\left.\right|_{\mathrm{C}-\mathrm{OH}} ^{\mathrm{CHO}}+\mathrm{Cu}^{42}+\left.\mathrm{H}_{2} \mathrm{O} \stackrel{\mathrm{iC}}{\longrightarrow}\right|_{\mathrm{H}-\mathrm{C}-\mathrm{OH}} ^{\mathrm{COOH}}+\mathrm{CU}_{2} \mathrm{O} \mid+2 \mathrm{H}^{+}\right]$

Gambar 2.26 Reaksi Karbohidrat Pereduksi dengan Pereaksi Benedict (Fessenden,1986)

3. Uji Asam Pikrat

Trinitrofenol atau asam pikrat jenuh dalam suasana basa suasana basa dapat digunakan untuk menunjukkan adanya kabohidrat pereduksi. Pada $5 \mathrm{ml}$ larutan karbohidrat pereduksi ditambahkan 2-3 $\mathrm{ml}$ asam pikrat dan $1 \mathrm{ml}$ natrium karbonat $10 \%$. Pada pemanasan, terjadi perubahan warna kuning menjadi merah. Reaksi yang terjadi dalam uji ini adalah oksidasi karbohidrat pereduksi menjadi asam onat dan reduksi asam pikrat yang berwarna kuning menjadi asam pikramat yang berwarna merah.

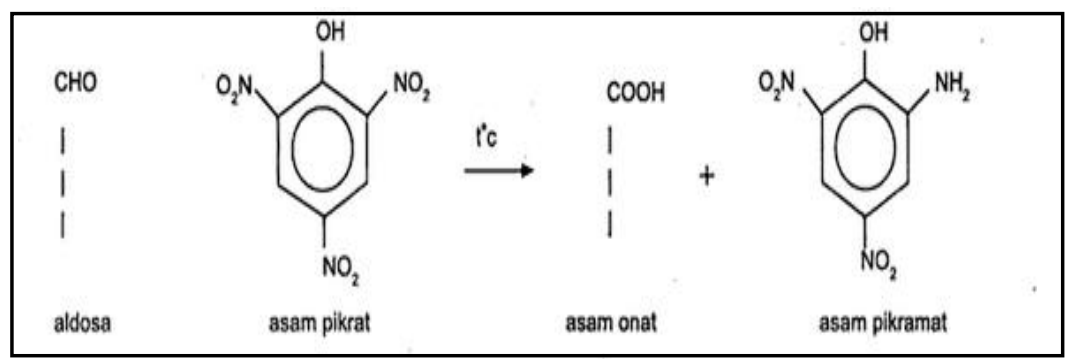

Gambar 2.27 Reaksi Karbohidrat Pereduksi dengan Asam Pikrat (Fessenden,1986) 
4. Uji Tollens

Pereaksi Tollens dibuat dengan mereaksikan larutan perak nitrat dengan larutan amonium hidroksida secara perlahan sehingga endapan yang mula-mula terbentuk larut. Bila Karbohidrat pereduksi dipanaskan dengan pereaksi Tollens dalam tabung reaksi maka akan terbentuk lapisan tipis menyerupai cermin pada bagian bawah tabung percobaan. Pada proses ini, karbohidrat pereduksi dioksidasi menjadi asam onat yang segera membentuk garam Amonium, sedangkan pereaksi Tollens direduksi sehingga dibebaskan logam perak yang segera melekat pada bagian bawah dinding tabung percobaan berupa lapisan tipis menyerupai cermin.

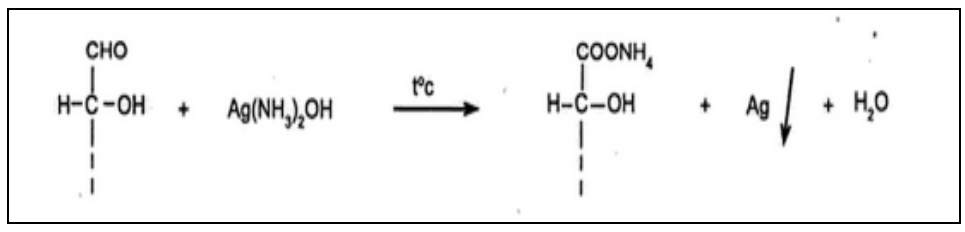

Gambar 2.28 Uji Tollens (Fessenden,1986)

5. Uji Barfoed

Pereaksi Barfoed bersifat asam. Pereaksi ini dibuat dengan melarutkan 13,3 gram kristal kupri sulfat netral dalam $200 \mathrm{ml}$ air. Setelah disaring, filtrat ditambah dengan $1,8 \mathrm{ml}$ asam asetat glasial. Pada pemanasan karbohidrat pereduksi dengan pereaksi Barfoed sebagai ion kupri $\left(\mathrm{Cu}^{2+}\right)$ menjadi endapan kupro oksida.

Suasana asam dalam pereaksi Barfoed dapat mengakibatkan waktu terjadinya pengendapan kupro oksida pada reaksi dengan disakarida dan monosakarida berbeda. Pada konsentrasi dan kondisi yang sama, disakarida 
memberikan endapan lebih lambat daripada monosakarida. Berdasarkan hal ini, uji Barfoed dapat digunakan untuk membedakan disakarida dan monosakarida.

\section{Uji Khusus Identifikasi Ketosa}

1. Reaksi Selliwanof

Reaksi selliwanof adalah suatu reaksi untuk mengidentifikasi adanya gugus keton pada suatu sakarida. Reagen selliwanof terdiri atas 0,5\% resorsinol dan $5 \mathrm{NHCl}$.

Reaksi positif apabila terbentuk warna merah. $\mathrm{HCl}$ akan mengubah heksosa menjadi hidroksi metal furfural yang kemudian akan bereaksi dengan resorsinol membentuk kompleks yang berwarna merah.

Kereaktifan aldosa dan ketosa sangatlah berbeda. Aldosa untuk terhidrolisis membutuhkan asam pekat sedangkan ketosa membutuhkan asam encer sehingga hidroksi metal furfural dari aldosa sedikit. Sedangkan untuk ketosa hidroksi metal furfural yang terbentuk banyak. Karena itulah reaksi ini spesifik untuk fruktosa yang termasuk ketoheksosa.

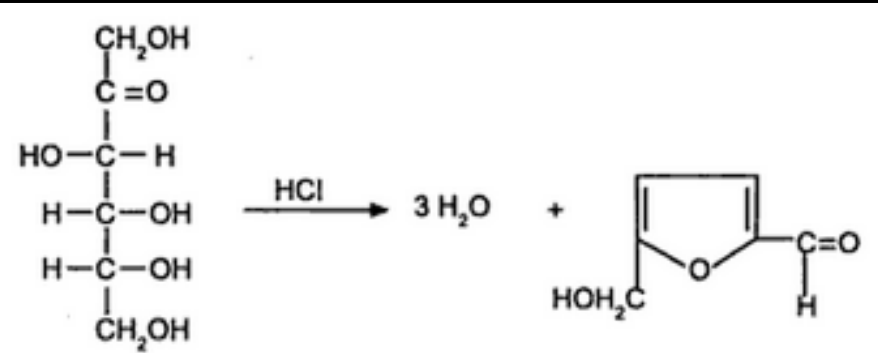

Fruktosa hidroksimetilfurfural

Gambar 2.29 Reaksi Dehidrasi Fruktosa (Fessenden,1986) 

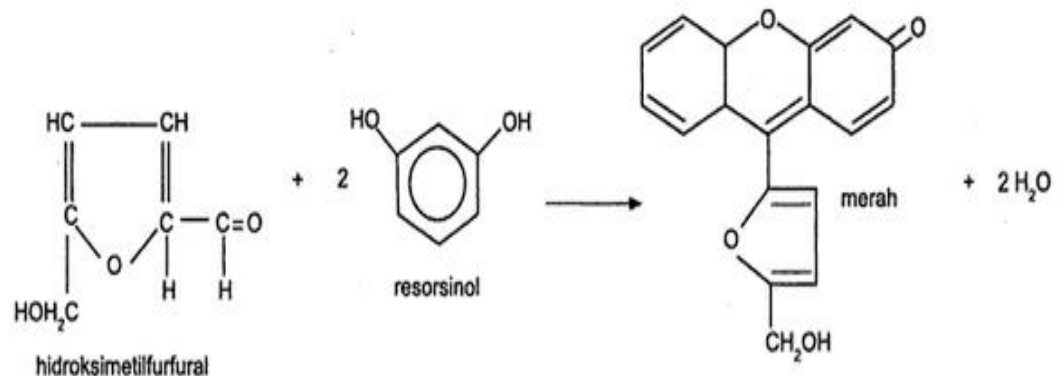

hidroksimetilfurfural

Gambar 2.30 Reaksi Kondensasi Hidroksimetilfurfural dengan Resorsinol (Fessenden,1986)

\section{Uji Khusus Identifikasi Pentosa}

1. Uji Bial

Pereaksi Bial dapat dibuat dengan melarutkan 1,5 gram orsinol dalam $500 \mathrm{ml}$ asam klorida pekat, kemudian ditambah dengan 20-30 tetes feriklorida 10\%. Pendidihan aldopentosa dengan pereaksi Bial akan menghasilkan larutan berwarna hijau.

2. Uji Tauber

Reaksi Tauber dapat digunakan untuk mengidentifikasi pentosa, tetapi tidak berlaku terhadap heksosa. Reagen tauber berisi larutan $4 \%$ benzidin dalam asam asetat glasial. Reaksi yang terjadi adalah pentosa dihidrolisis oleh asam asetat glasial menjadi furfural. Furfural yang terbentuk akan bereaksi dengan $4 \%$ benzidin membentuk kompleks senyawa berwarna merah anggur. Arabinosa termasuk pentosa (aldopentosa) sehingga memberi reaksi positif terhadap reagen Tauber, sedang glukosa dan fruktosa termasuk heksosa sehingga reaksinya 
negatif. Bila aldopentosa dididihkan dengan pereaksi Tauber, dihasilkan warna pink sampai merah setelah didinginkan. 


\section{RANGKUMAN}

1. Sakarida adalah nama lain dari karbohidrat dan berasal dari bahasa Arab "sakkar" yang berarti gula.

2. Karbohidrat merupakan suatu senyawa organik polihidroksialdehid atau polihidroksiketon.

3. Rumus umum dari karbohidrat adalah $\mathrm{C}_{n}\left(\mathrm{H}_{2} \mathrm{O}\right)_{n}$ atau $\mathrm{C}_{\mathrm{n}} \mathrm{H}_{2 \mathrm{n}} \mathrm{O}_{\mathrm{n}}$.

4. Fungsi Karbohidrat antara lain :

a. Sumber Energi utama tubuh

b. Memperlancar pencernaan

c. Sebagai pemanis alami

5. Karbohidrat digolongkan menjadi 4 golongan utama yaitu:

a. Monosakarida

b. Disakarida

c. Oligosakarida

d. Polisakarida

6. Penyakit kekurangan karbohidrat antara lain :

a. Obesitas

b. Marasmus

c. Diabetes Militus

d. Laktose intolerance

7. Identifikasi Karbohidrat :

a.Uji Umum Identifikasi Karbohidrat

i. Uji Molisch

ii. Uji Anthron

iii. Percobaan lod

iv. Reaksi Fenilhidrazin (pembentukan osazon)

b. Uji Khusus Karbohidrat Pereduksi

i. Uji Fehling

ii. Uji Benedict 
iii. Uji Asam Pikrat

iv. Uji Tollens

v. Uji Barfoed

c. Uji Khusus Identifikasi Ketosa

Reaksi Selliwanof

d. Uji Khusus Identifikasi Pentosa

i. Uji Bial

ii. Uji Tauber 


\section{LATIHAN SOAL}

I. Isilah Jawaban Dibawah ini!

Nama lain karbohidrat adalah (1)......... Karbohidrat merupakan senyawa organik (2)......... dan (3)...........

Karbohidrat dapat digolongkan menjadi 4 klasifikasi yaitu (4)...... (5)...... (6)..... dan (7)..............

Manfaat polisakarida untuk tubuh antara lain sebagai (8)..... (9)..... dan (10)

\section{Pilihlah Jawaban yang Benar!}

1. Rumus umum karbohidrat adalah
a. $\mathrm{C}_{n}\left(\mathrm{H}_{2} \mathrm{O}\right)_{n}$
c. $\mathrm{CH}_{2} \mathrm{OH}$
b. $\mathrm{H}_{2} \mathrm{O}$
d. $\mathrm{NH}_{4}$

2. Ikatan antara dua molekul monosakarida disebut ikatan
a. Ion
c. Glikosidik
b. Atom
d. Peptida

3. Karbohidrat yang terdiri atas 3-10 unit monosakarida dan digabungkan dengan ikatan kovalen disebut
a. Monosakarida
c. Disakarida
b. Oligosakaridad. Fruktosa

4. Polisakarida sebagai bahan pembangun tubuh adalah
a. Karbohidrat
c. Fruktosa
b. Glukosa
d. Selulosa

5. Hasil akhir reaksi uji molisch adalah
a. Cincin berwarna ungu
b. Endapan merah bata
c. Larutan berwarna hijau
d. Senyawa berwarna merah 


\section{Cocokan Jawaban Berikut ini!}

1. Salah Satu Fungsi Karbohidrat adalah.........

2. Contoh monosakarida adalah.......

3. Contoh Oligosakarida adalah.....

4. Contoh polisakarida sebahai bahan nutrisi adalah....

5. Penyakit yang berhubungan dengan karbohidrat adalah....

\section{Pilihan Jawaban :}
A. Rafinosa
B. Pemanis alami
C. Laktose intolerance
D. Amilum
E. Ribosa

\section{Benar atau Salah Pernyataan Dibawah ini!}

1. Dimer adalah senyawa kimia yang terdiri dari dua molekul yang identik atau mirip dan terikat bersama-sama (B / S)

2. Monosakarida yang termasuk tretosa yaitu gliseraldehida dan dihidroksiaseton (B / S)

3. Disakarida dengan gugus hemiasetal bebas merupakan senyawa dengan satu unit glikosil yang dapat digantikan dengan atom hidrogen dari gugus hidroksi alkoholik dari unit lainnya sehingga mempunyai gugus - $\mathrm{OH}$ glikosidik dan bersifat mereduksi, contohnya adalah maltosa dan laktosa (B / S)

4. Fruktosa dihidrolisis kemudian dipanaskan dengan asam nitrat akan terbentuk asam musat (B / S)

5. Gugus aldehida dan keton bebas dalam molekul karbohidrat dapat mereduksi $\mathrm{Cu}^{2+}$ yang terdapat dalam pereaksi Fehling menjadi $\mathrm{Cu}^{+}$berupa endapan merah $\mathrm{Cu}_{2} \mathrm{O}$ merupakan prinsip Uji Molisch (B / S) 


\section{Jelaskan Pertanyaan dibawah ini!}

1. Jelaskan reaksi terbentuknya karbohidrat?

2. Mengapa karbohidrat sangat dibutuhkan oleh tubuh?

3. Apa yang dimaksud gula pereduksi?

4. Bagaimana cara membedakan karbohidrat yang bersifat mereduksi dan tidak dapat mereduksi?

5. Jelaskan perbedaan identifikasi karbohidrat secara percobaan Molich dengan reaksi Selliwanof? 


\section{BAB III}

\section{PROTEIN}

\begin{tabular}{|l|ll|}
\hline Tujuan Instruksional & \multicolumn{2}{|l|}{ Materi } \\
\hline Mahasiswa memahami & 3.1 & Pendahuluan \\
tentang Asam Amino & 3.2 & Asam Amino \\
dan Protein sehingga & 3.3 & Fungsi Asam Amino \\
dapat diterapkan dalam & 3.4 & Klasifikasi Asam Amino \\
bidang kesehatan sesuai & 3.5 & Peptida \\
dengan perkembangan & 3.6 & Protein \\
sains dan teknologi. & 3.7 & Fungsi Protein \\
& 3.8 & Klasifikasi Protein \\
& 3.9 & Struktur Protein \\
& 3.10 & Denaturasi Protein \\
& 3.11 & Penyakit Yang Berhubungan \\
& 3.12 & Idengan Protein \\
\hline
\end{tabular}

\subsection{Pendahuluan}

Protein merupakan makromolekul yang terpenting bagi makhluk hidup. Protein yang dibutuhkan oleh makhluk hidup berasal dari hewan sehingga disebut protein hewani sedangkan protein yang berasal dari tumbuhan disebut protein nabati. Protein berasal dari kata protos atau proteos yang berarti pertama. Hanya terdapat 20 macam asam amino yang terdapat dialam. Keduapuluh asam amino ini jika digabungkan akan membentuk otot, urat, sutera, antibodi dengan berbagai cara. Sebelum membahas protein, pada bab ini akan dibahas asam amino terlebih dahulu. 


\subsection{Asam Amino}

Asam amino adalah suatu senyawa yang mengandung gugus amino dan gugus karboksil pada atom $C$ yang sama yaitu $C-\alpha$. Rumus umum asam amino adalah

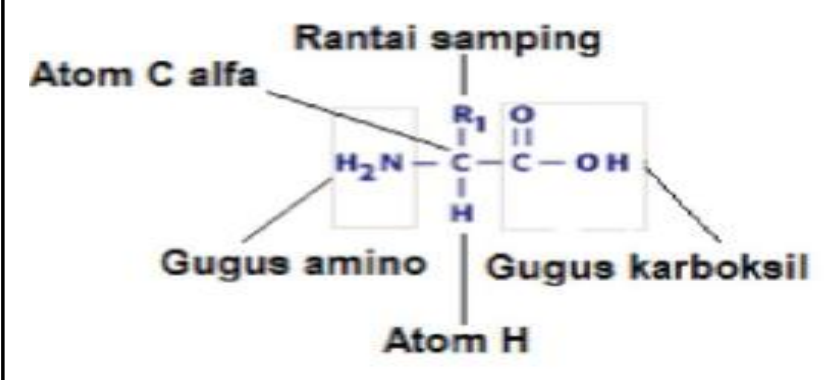

Gambar 3.1 Struktur Asam Amino (Fessenden,1986)

Masing-masing asam amino memiliki gugus $\mathrm{R}$ atau rantai samping yang berbeda. Gugus R dari asam amino bervariasi dalam hal ukuran, bentuk, muatan, kapasitas pengikatan hidrogen serta reaktivitas kimia. Asam Amino larut dalam air dan pelarut polar, tetapi tidak larut dalam pelarut organik non polar seperti eter, aseton, benzena dan kloroform. Titik lebur asam amino lebih tinggi dibanding dengan asam karboksilat atau amina.

Asam amino mempunyai momen dipol yang besar. Asam amino kurang bersifat asam dibandingkan asam karboksilat dan kurang bersifat basa dibandingkan amina, hal ini karena suatu asam amino mengandung gugus amino yang bersifat basa dan gugus karboksil yang bersifat asam dalam molekul yang sama. Suatu asam amino mengalami reaksi asam-basa internal yang menghasilkan suatu ion dipolar yang disebut zwitterion (dari bahasa jerman zwitter, hibrida). Karena terjadinya muatan ion, suatu asam amino mempunyai banyak sifat garam. pKa suatu 
asam amino berasal dari $-\mathrm{NH}_{3}{ }^{+}$sedangkan pKb berasal dari $-\mathrm{CO}_{2}{ }^{-}$ yang bersifat basa sangat lemah.

Asam amino bersifat asam jika mengandung gugus karboksil dalam rantai sampingnya. Asam amino bersifat basa jika mengandung gugus amino dalam rantai samping. Asam amino bersifat netral jika rantai samping mengandung $\mathrm{OH}, \mathrm{SH}$ atau gugus polar.

Tabel 3.1 Nama-nama Asam Amino (Fessenden,1986)

\begin{tabular}{|c|c|c|}
\hline $\begin{array}{l}\text { Nama } \\
\text { Amino }\end{array}$ & Singkatan & Struktur Kimia \\
\hline Alanin & ala & ${ }^{+} \mathrm{H}_{3} \mathrm{~N}-\underset{\alpha}{\mathrm{C}} \mathrm{CH}-\mathrm{CH}_{2}=9.7 \quad$ \\
\hline Arginin & arg & 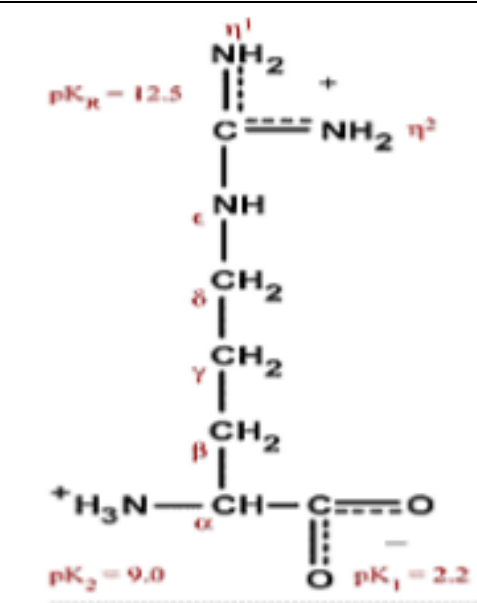 \\
\hline
\end{tabular}




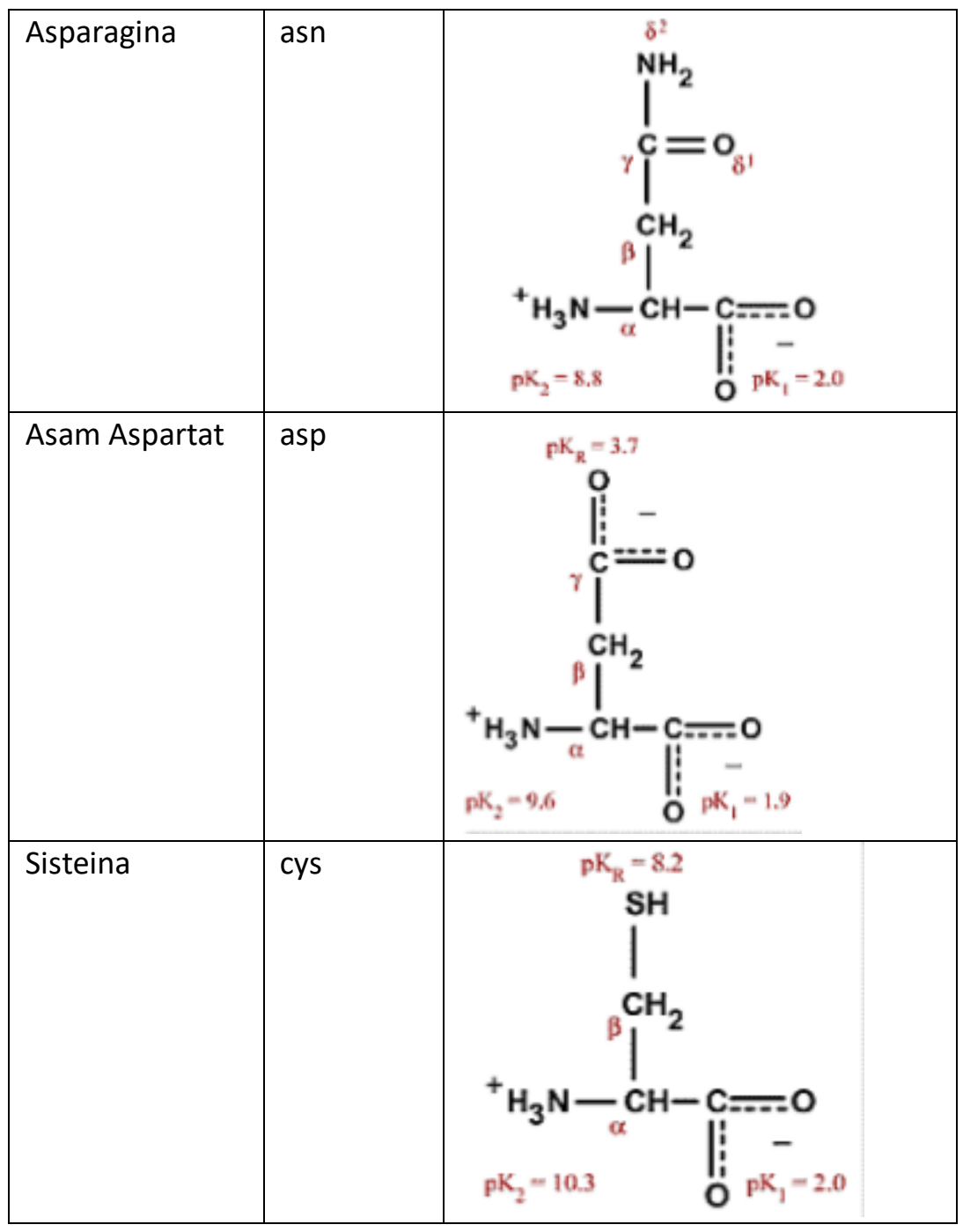




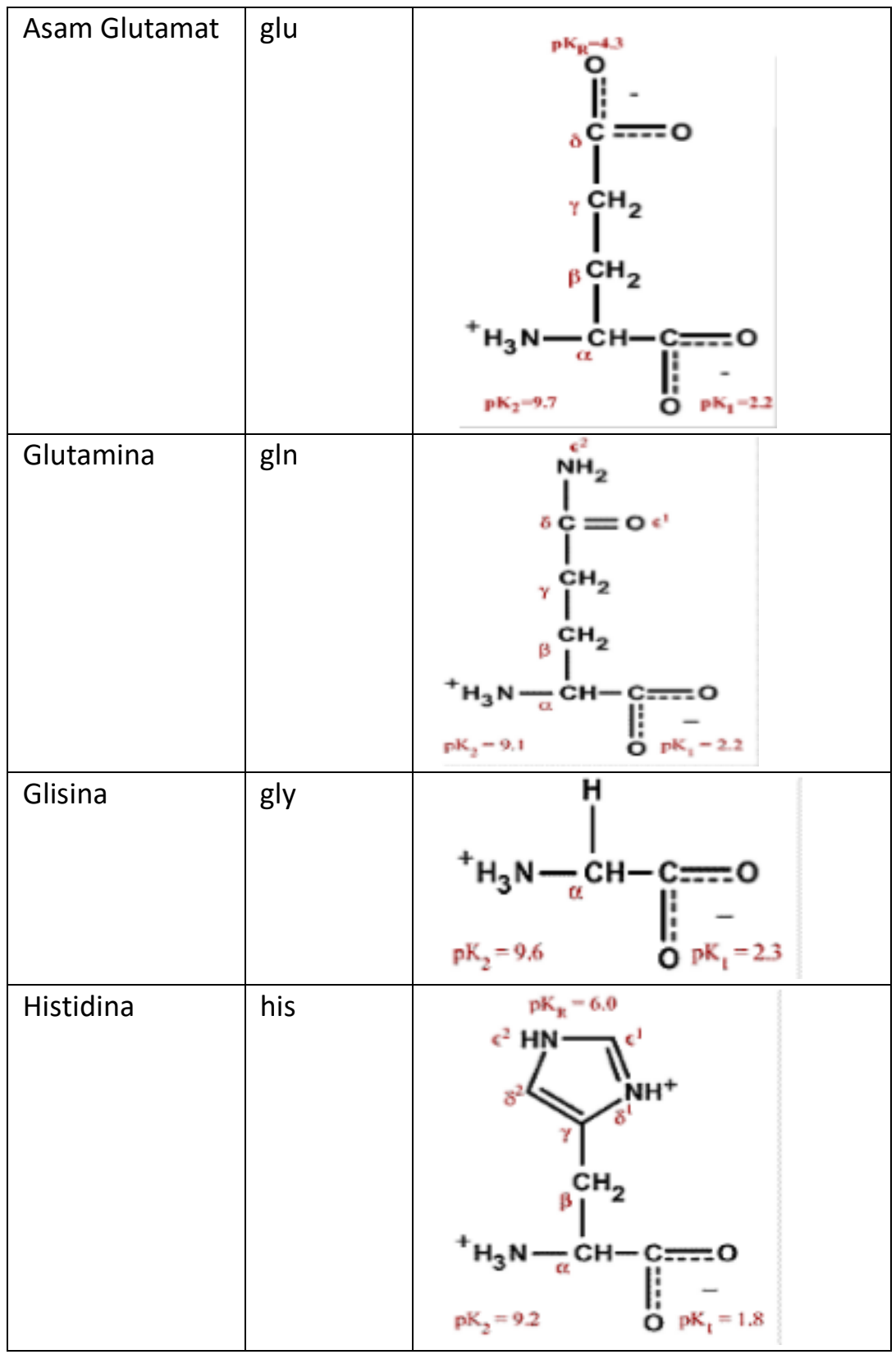




\begin{tabular}{|c|c|c|}
\hline Isoleusina & ile & ( \\
\hline Leusina & leu & 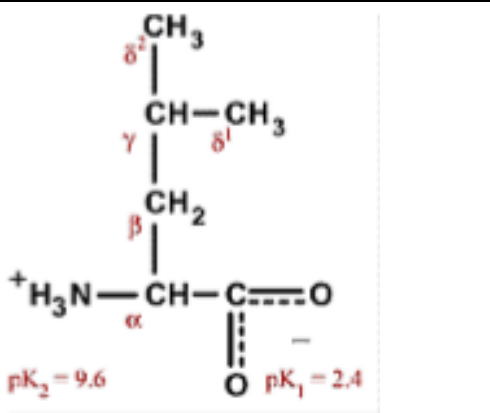 \\
\hline Lisina & lys & (1) \\
\hline
\end{tabular}




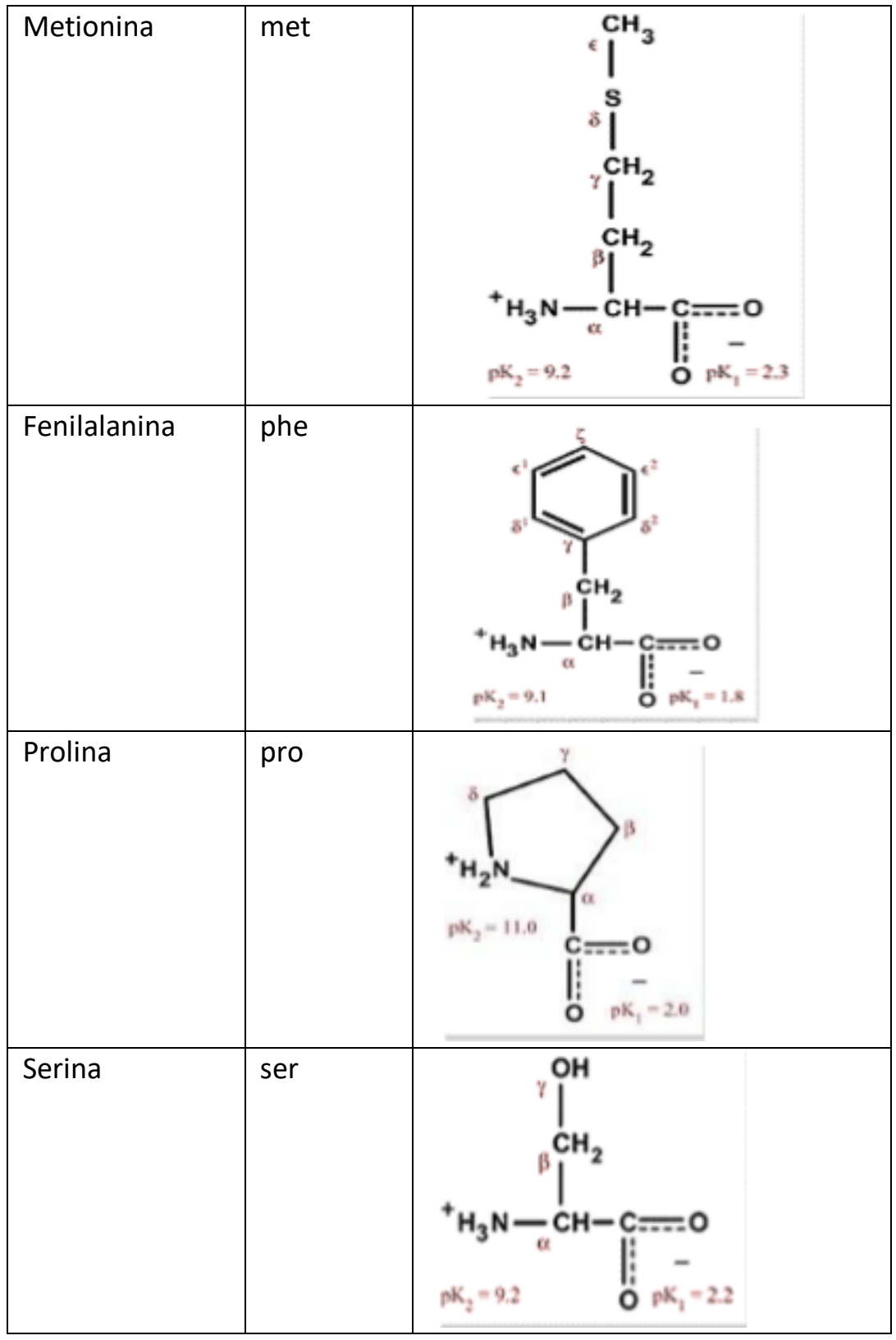




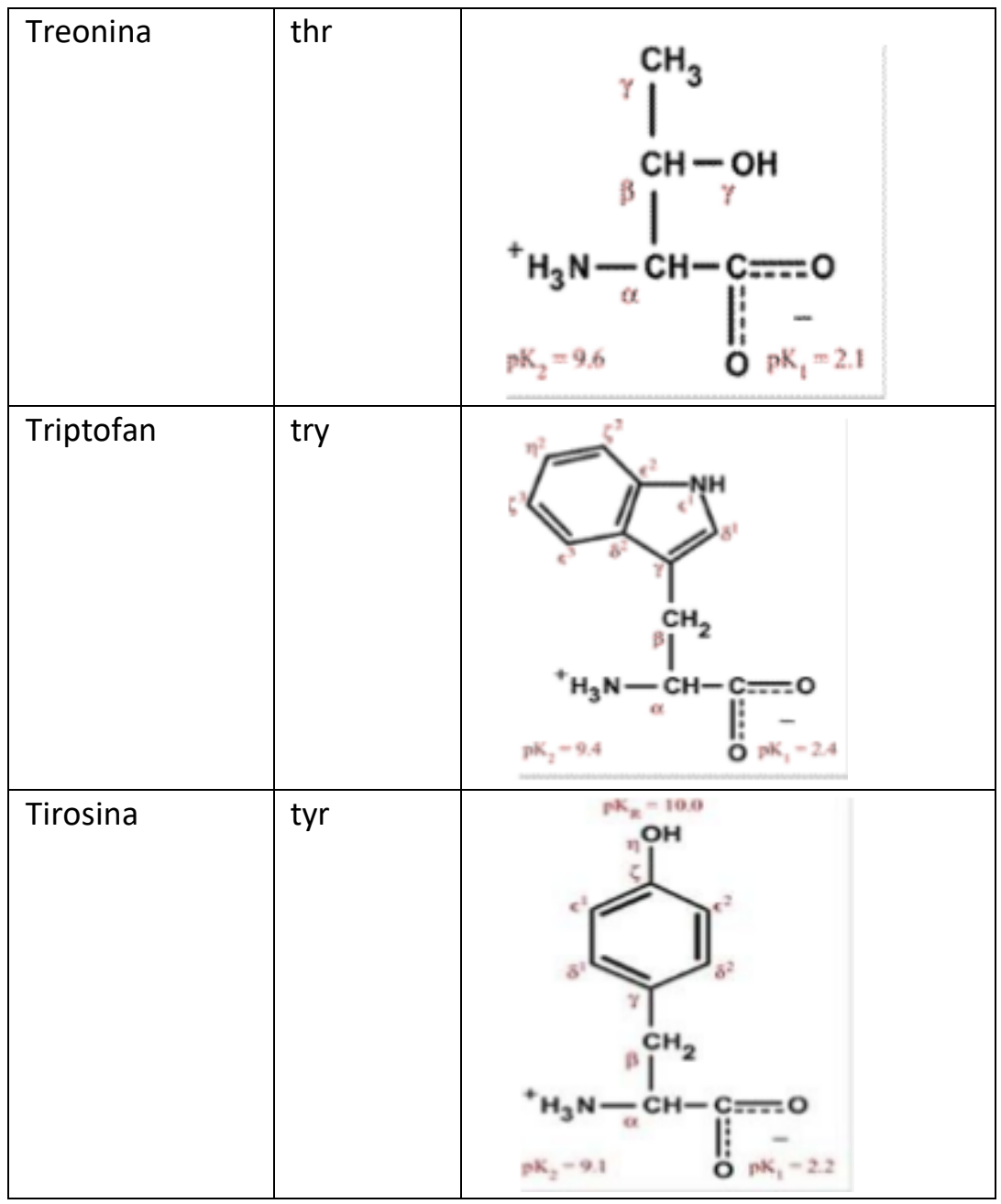




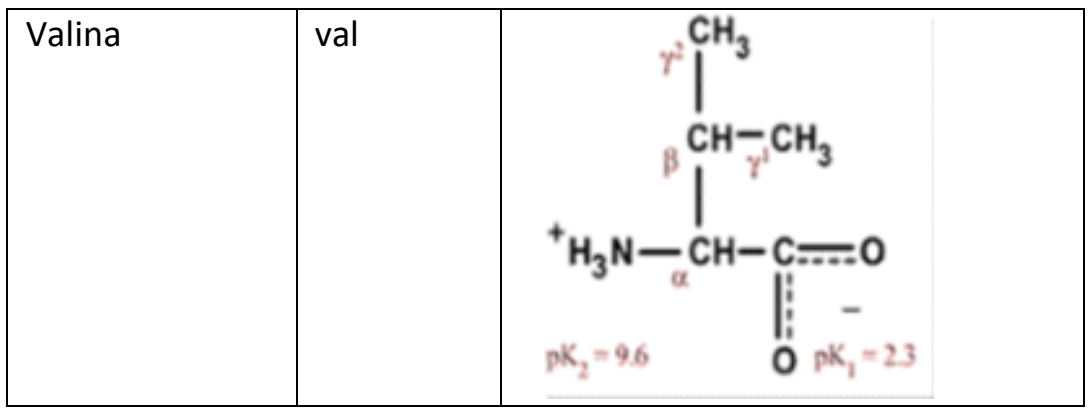

Asam amino mengandung ion karboksilat $\left(-\mathrm{CO}_{2}^{-}\right)$dan ion amonium $\left(\mathrm{NH}_{3}{ }^{+}\right)$, oleh karena itu asam amino bersifat amfoter. Asam amino bersifat amfoter, artinya dapat bereaksi dengan larutan asam ataupun basa dan menghasilkan suatu kation atau anion.

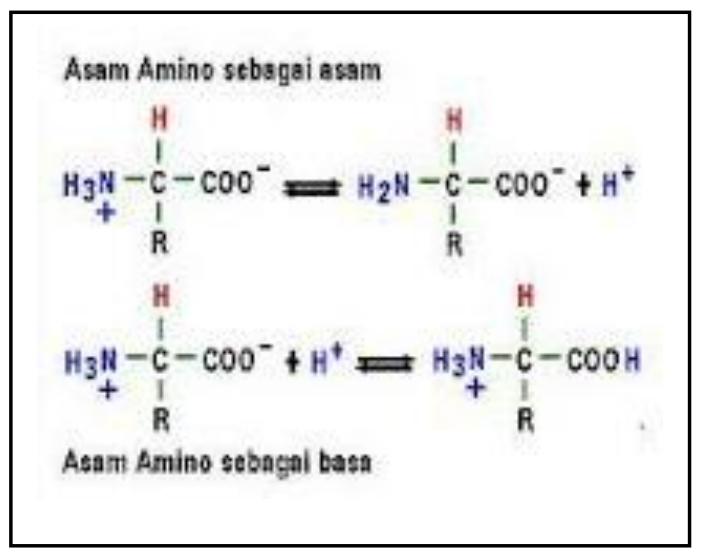

Gambar 3.2 Asam amino bersifat amfoter (Fessenden,1986)

Apabila asam amino larut dalam air, gugus karboksilat akan melepaskan ion $\mathrm{H}^{+}$, sedangkan gugus amina akan menerima ion $\mathrm{H}^{+}$, reaksinya :

$-\mathrm{COOH} \leftrightarrow-\mathrm{COO}^{-}+\mathrm{H}^{+}$

$$
-\mathrm{NH}_{2}+\mathrm{H} \leftrightarrow-\mathrm{NH}_{3}{ }^{+}
$$


Titik isoelektrik (pl) suatu asam amino adalah suatu nilai $\mathrm{pH}$ dimana asam amino memiliki jumlah muatan negatif yang sama dengan jumlah muatan positifnya, atau dengan kata lain asam amino bermuatan netral atau tidak bermuatan. Titik isoelektrik dapat ditentukan dengan elektroforesis dan titrasi. Titik isoelektrik suatu asam amino adalah suatu tetapan fisis. Nilai titik isoelektrik asam amino netral ( $\mathrm{pl}$ ) antara 5,5-6,0. Titik isoelektrik asam amino asam (pl) 3. Titik isoelektri asam amino basa (pl) antara 9-10.

\subsection{Fungsi Asam Amino}

A. Penyusun protein, termasuk enzim.

B. Sebagai kerangka dasar sejumlah senyawa penting dalam metabolisme (terutama vitamin, hormon, dan asam nukleat)

C. Pengikat logam penting yang di perlukan dalam reaksi enzimatik (kofaktor).

D. Fenilalanin : Membantu dalam meningkatkan daya memori dan juga membantu untuk menjaga sistem saraf yang sehat

E. Valin : Membantu dalam pertumbuhan otot.

F. Treonin : Meningkatkan fungsi sistem kekebalan tubuh.

G. Tryptophan : Membantu dalam menjaga nafsu makan kita.

$\mathrm{H}$. Isoleusin : Membantu dalam sintesis hemoglobin dan merupakan komponen utama dari RBC (sel darah merah)

I. Metionin : Membantu dalam menjaga kulit yang baik dan sehat.

J. Leusin : Meningkatkan sintesis hormon pertumbuhan.

K. Lysine : Membantu dalam sintesis enzim dan hormon lainnya. 
L. Histidin : Membantu dalam produksi dan sintesis dari RBC (sel darah merah) dan WBC (sel darah putih)

M. Alanin : Membantu dalam penghapusan racun dari tubuh kita.

N. Sistein : Menyediakan resistensi terhadap tubuh kita dan menghambat pertumbuhan rambut, kuku dan lain-lain

O. Sistin : Berfungsi sebagai antioksidan dan melindungi tubuh kita terhadap radiasi dan polusi.

P. Glutamin : Hal ini diperlukan untuk sintesis RNA dan DNA.

Q. Glycine : Sebagai neurotransmitter dan memainkan peran penting dalam penyembuhan luka.

R. Glutamat : Membantu dalam penghapusan racun dari tubuh kita.

S. Arginin : Membantu biosintesis protein.

T. Tirosin : Membantu dalam produksi hormon T3 dan T4 tiroid.

U. Serin : Membantu dalam pertumbuhan otot.

V. Asparagin : Membantu dalam formasi purin dan pirimidin untuk sintesis DNA.

W. Asam aspartat: Membantu. sintesis asam amino lainnya.

$X$. Prolin : Membantu dalam regenerasi kulit baru.

\subsection{Klasifikasi Asam Amino}

\section{A. Asam Amino Berdasarkan Rantai Samping}

1. Asam amino alifatik: Alanine, glisin, isoleusin, leusin, prolin dan valin.

2. Asam amino aromatik: fenilalanin, triptofan dan tirosin

3. Asam amino gugus $\mathrm{NH}_{2}$ dan2 gugus $\mathrm{COOH}$ : asam aspartat dan asam glutamat.

4. Asam amino dasar: arginin, histidin dan lisin. 
5. Asam amino Hidroksil: serin dan treonin.

6. Asam amino mengandung Sulfur: sitosin dan metionin.

7. Asam amino mengandung gugus amida: asparagines dan glutamin.

\section{B. Asam Amino Esensial}

Ada beberapa asam amino yang penting bagi manusia dan tidak dapat disintesis oleh tubuh seperti: arginin, fenilalanin, Valin, treonin, triptofan, isoleusin, metionin, leusin, lisin, dan histidin.

Kenari, almond, kacang Brasil, kacang mete dan kacang tanah adalah sumber yang kaya dari asam amino esensial L-arginine, Arginine, isoleusin dan fenilalanin. Ikan adalah sumber dari isoleusin, lisin dan metionin. Kacang kedelai kaya isoleusin, lisin, metionin, triptofan dan valine. Telur merupakan sumber yang baik dari metionin, isoleusin, lisin dan Tryptophan

\section{Asam Amino Non esensial}

Asam amino non esensial adalah asam amino yang dapat dengan mudah disintesis oleh tubuh kita. Asam amino non esensial adalah: Alanine, sistein, sistin, glutamin, glisin, glutamat, arginin, tirosin, serin, asparagines, asam aspartat, selenocysteine dan prolin.

\subsection{Peptida}

Peptida adalah suatu amida yang dibentuk dari dua asam amino atau lebih. Ikatan peptida adalah ikatan amida antara suatu gugus $\alpha$-amino dari suatu asam amino dan gugus karboksil dari asam amino lain.

Peptida dan protein merupakan polimer kondensasi asam amino dengan penghilangan unsur air dari gugus amino dan gugus karboksil. Suatu poliamida dengan residu asam amino kurang dari 
50 dikelompokkan sebagai peptida, sedangkan poliamida yang lebih besar dianggap sebagai protein.

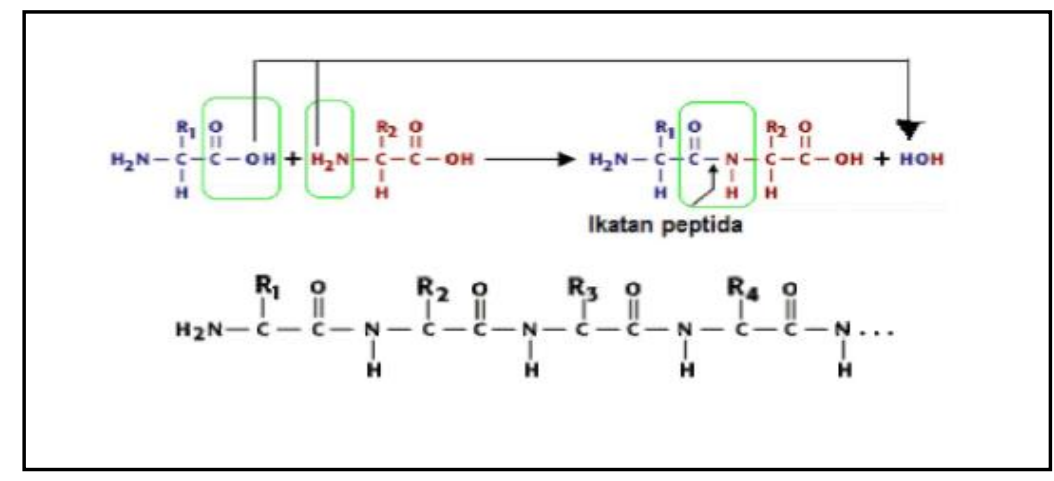

Gambar 3.3 Ikatan Peptida (Fessenden,1986)

\subsection{Protein}

Protein adalah senyawa organik komplek berbobot molekul besar yang terdiri dari asam amino yang dihubungkan satu sama lain dengan ikatan peptida. Struktur protein mengandung $\mathrm{N}$ (15,30-18\%), C (52,40\%), H (6,90-7,30\%), O (2123,50\%), S (0,8-2\%), disamping $\mathrm{C}, \mathrm{H}, \mathrm{O}$ (seperti juga karbohidrat dan lemak), dan $\mathrm{S}$ kadang-kadang $\mathrm{P}$, Fe dan $\mathrm{Cu}$ (sebagai senyawa kompleks dengan protein). Sumber protein anatara lain terdapat pada daging, ikan dan telur, serangga, produk susu, biji dan kacang-kacangan.

\subsection{Fungsi Protein}

A. Sebagai pertumbuhan dan pemeliharaan tubuh.

B. Pembentukan senyawa-senyawa penting tubuh, seperti hormon, enzim, dan hemoglobin.

C. Pembentuk antibodi tubuh

Protein yang digunakan untuk memerangi organisme atau bahan asing lain yang masuk dalam tubuh. 
D. Berperan dalam pengangkutan zat-zat gizi, yakni pengangkutan dari saluran cerna ke dalam darah dan dari darah ke jaringan-jaringan serta ke sel-sel.

E. Sumber energi, selain karbohidrat dan lemak, protein juga merupakan sumber energi tubuh. Jika tubuh kekurangan energi, fungsi protein sebagai pembangun berkurang untuk menyediakan energi

F. Mengganti Sel yang Rusak

Protein juga dapat mengganti sel yang rusak dan membentuk sel baru. Sehingga protein juga berfungsi sebagai zat pembangun terutama sel otot.

G. Sebagai Pembawa Materi Genetika

Protein juga berfungsi sebagai pembawa materi genetika dengan tahapan yang disebut sintesis protein. Dari proses inilah ditentukan sifat dan keunikan dari setiap individu.

\subsection{Klasifikasi Protein}

A. Berdasarkan bentuknya, dikelompokkan sebagai berikut :

1. Protein Serat

Protein serat disebut juga fibrous protein atau protein struktural yang membentuk kulit, otot, dinding pembuluh darah dan rambut. Protein serat memiliki molekul panjang mirip benang yang liat dan tidak larut dalam air.

2. Protein Globular

Protein Globular memiliki bentuk agak bulat karena rantai-rantai melipat bertumpukan. Protein Globular larut dalam air dan melakukan beberapa fungsinya dalam suatu organisme. Contoh protein 
globular adalah hemoglobin (mengangkut oksigen ke selsel), Insulin (membantu dalam metabolisme karbohidrat), antibodi (membuat protein asing menjadi tidak aktif).

\section{B. Berdasarkan kelarutannya, dibagi menjadi :}

1. Albumin

Albumin larut dalam air, terkoagulasi oleh panas. Contohnya adalah albumin telur, albumin serum.

2. Globulin

Globulin tidak larut air, terkoagulasi oleh panas, larut dalam larutan garam, mengendap dalam larutan garam, konsentrasi meningkat. Contohnya adalah Ixiosinogen dalam otot.

3. Glutelin

Glutelin tidak larut dalam pelarut netral, larut dalam asam atau basa encer. Contohnya Histo dalam $\mathrm{Hb}$.

4. Plolamin/Gliadin

Plolamin/Gliadin larut dalam alkohol $70-80 \%$ dan tidak larut dalam air maupun alkohol absolut. Contohnya adalah prolaamin dalam gandum.

5. Histon

Histon larut dalam air, tak larut dalam ammonia encer. Contohnya adalah Hisron dalam $\mathrm{Hb}$.

6. Protamin

Protamin larut dalam air dan tak terkoagulasi oleh panas. Contohnya salmin dalam ikatan salmon. 


\section{Berdasarkan fungsi biologinya, dibagi menjadi :}

1. Enzim

Golongan protein yang terbesar dan paling penting, berfungsi sebagai katalisator reaksi kimia dalam jasad hidup. Molekul enzim berbentuk bulat (globular). Contoh enzim adalah ribonuklease, suatu enzim yang mengkatalisa hidrolisa RNA (asam poliribonukleat).

2. Protein Transport

Protein pengangkut mempunyai kemampuan mengikat molekul tertentu dan melakukan pengangkutan berbagai macam zat melalui aliran darah. Contohnya adalah hemoglobin yang terdiri atas gugus senyawa heme mengandung besi terikat pada protein globin, berfungsi sebagai alat pengangkut oksigen dalam darah.

3. Protein Nutrien dan Penyimpan

Misalnya biji dari tanaman menyimpan protein nutrien yang dibutuhkan untuk pertumbuhan. Ferritin adalah jaringan hewan yang merupakan protein penyimpan besi.

4. Protein Kontraktil

Protein kontraktil merupakan golongan protein yang berperan dalam proses gerak. Sebagai contoh misalnya; miosin, merupakan unsur filamen tak bergerak dalam myofibril.

5. Protein Pembangun

Protein pembangun berfungsi sebagai unsur pembentuk struktur. Contohnya glikoprotein, merupakan penunjang struktur dinding sel; struktur membrane, merupakan protein komponen membrane sel; $\alpha$-Keratin, terdapat dalam kulit, bulu ayam, dan kuku; sklerotin, 
terdapat dalam rangka luar insekta; fibroin, terdapat dalam kokon ulat sutra; kolagen, merupakan serabut dalam jaringan penyambung.

6. Protein Pelindung atau Pertahanan

Melindungi organisme dari serangan spesies lain. Contohnya adalah antibodi merupakan protein yang hanya dibentuk jika ada antigen dan dengan antigen yang merupakan protein asing, dapat membentuk senyawa kompleks.

7. Protein Pengatur

Beberapa protein membantu mengatur aktivitas seluler atau fisiologis misalnya hormon. Contoh protein pengatur adalah insulin, berfungsi mengatur metabolisme glukosa.

\section{Berdasarkan sumbernya, dibagi menjadi :}

1. Protein hewani

Protein hewani adalah protein yang berasal dari hewan, Contoh daging sapi, daging ayam, susu, udang, telur, belut, ikan gabus.

2. Protein nabati

Protein nabati adalah protein yang berasal dari tumbuh-tumbuhan. Contoh jagung, kacang kedelai, kacang hijau, dan jenis kacang-kacangan lainnya yang mengandung protein tinggi.

\section{E. Berdasarkan hasil hidrolisanya, dibagi menjadi :}

1. Protein tunggal (protein sederhana)

Hasil hidrolisa dari asam-asam amino. Contohnya: albumin, globulin, keratin dan hemoglobin.

2. Protein jamak (protein konyugasi atau protein kompleks) 
Merupakan protein sederhana yang terikat dengan bahan-bahan non-asam amino. Contohnya adalah Lipoprotein terdapat dalam plasma-plasma yang terikat melalui ikatan ester dengan asam fosfat sepertu kasein dalam susu. Metaloprotein adalah protein yang terikat dengan mineral seperti feritin dan hemosiderin adalah protein dimana mineralnya adalah zat besi, tembaga dan seng.

\subsection{Struktur Protein}

\section{A. Struktur primer}

Struktur primer adalah urutan linier asam-asam amino yang membentuk rantai polipeptida. Terdapat pada rentetan asam amino

\section{B. Struktur sekunder}

Struktur sekunder protein bersifat reguler, pola lipatan berulang dari rangka protein. Suatu polipeptida cenderung membentuk struktur skunder karena regularitas rangka. Dua pola terbanyak adalah alpha helix dan beta sheet. Terdapat pada bentuk tulang belakang yang memiliki bentuk $\alpha$-spiral, lembar terwiru- $\beta$

C. Struktur tersier

Struktur tersier protein adalah lipatan secara keseluruhan dari rantai polipeptida sehingga membentuk struktur 3 dimensi tertentu. Sebagai contoh, struktur tersier enzim sering padat, berbentuk globuler. Terdapat pada protein globular.

\section{Struktur kuartener}

Beberapa protein tersusun atas lebih dari satu rantai polipeptida. Struktur kuartener menggambarkan subunitsubunit yang berbeda dipakai bersama-sama membentuk 
struktur protein yang kompleks rantai multiple (multichain). Sebagai contoh adalah molekul hemoglobin manusia yang tersusun atas 4 subunit.

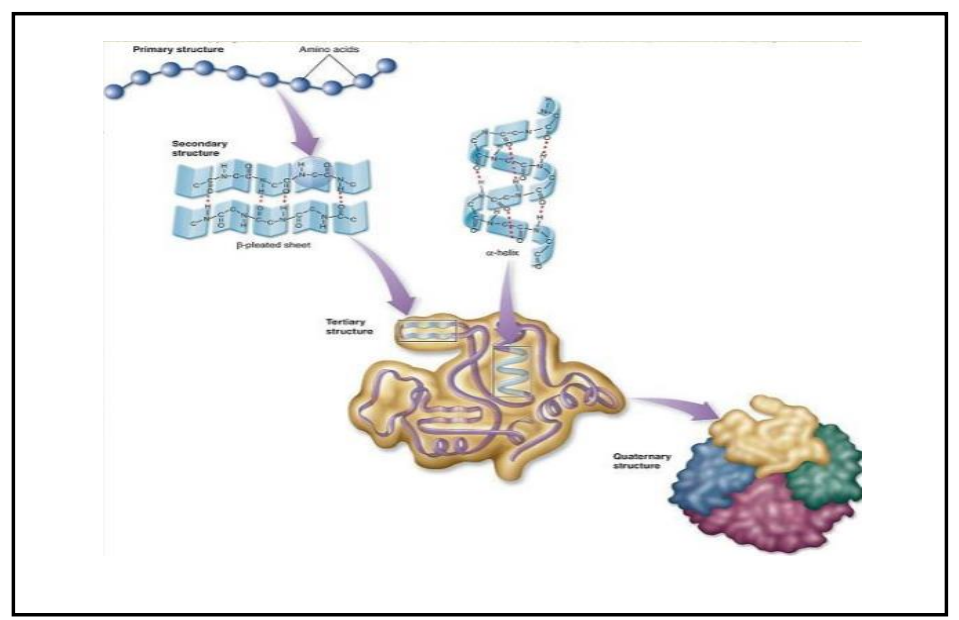

Gambar 3.4 Struktur Protein (Harper, 1980)

\subsection{Denaturasi}

Denaturasi adalah hilangnya sifat-sifat struktur lebih tinggi karena terpecahnya ikatan hidrogen, interaksi hidrofobik, ikatan garam dan terbukanya lipatan molekul protein sehingga hilangnya sifat biologis protein tersebut. Denaturasi bersifat reversibel jika suatu protein hanya mengalami kondisi denaturasi yang lembut seperti perubahan $\mathrm{pH}$. Renaturasi adalah suatu proses dimana protein dikembalikan ke lingkungan alamnya, sehingga protein ini memperoleh kembali struktur yang lebih tinggi. Renaturasi umunya berjalan sangat lambat atau tidak terjadi sama sekali. 
Faktor-faktor penyebab denaturasi yaitu

A. Perubahan Temperatur,

Panas dapat digunakan untuk memecahkan ikatan hidrogen dan interaksi hidrofobik non polar. Hal ini terjadi karena suhu tinggi dapat meningkatkan energi kinetik dan menyebabkan molekul penyusun protein bergerak atau bergetar sangat cepat sehingga mengacaukan ikatan molekul tersebut. Pemanasan akan membuat protein bahan terdenaturasi sehingga kemampuan mengikat airnya menurun. Hal ini terjadi karena energi panas akan mengakibatkan terputusnya interaksi non-kovalen yang ada pada struktur alami protein tapi tidak memutuskan ikatan kovalennya yang berupa ikatan peptida. Contohnya pemanasan pada telur yang akan mengakibatkan albumin membuka lipatan dan mengendap sehingga dihasilkan suatu zat putih

B. Denaturasi karena logam berat

Garam logam berat mendenaturasi protein sama dengan halnya asam dan basa. Garam logam berat umumnya mengandung $\mathrm{Hg}^{2+}, \mathrm{Pb}^{2+}, \mathrm{Ag}^{+} \mathrm{Tl}^{+}, \mathrm{Cd}^{2+}$ dan logam lainnya dengan berat atom yang besar. Reaksi yang terjadi antara garam logam berat akan mengakibatkan terbentuknya garam protein-logam yang tidak larut. Protein akan mengalami presipitasi bila bereaksi dengan ion logam. Pengendapan oleh ion positif (logam) diperlukan $\mathrm{pH}$ larutan diatas pl karena protein bermuatan negatif, pengendapan oleh ion negatif diperlukan $\mathrm{pH}$ larutan dibawah $\mathrm{pl}$ karena protein bermuatan positif. Ion-ion positif yang dapat mengendapkan protein adalah; $\mathrm{Ag}^{+}, \mathrm{Ca}^{2+}, \mathrm{Zn}^{2+}, \mathrm{Hg}^{2+}, \mathrm{Fe}^{2+}$, $\mathrm{Cu}^{2+}$ dan $\mathrm{Pb}^{2+}$, sedangkan ion-ion negatif yang dapat 
mengendapkan protein adalah; ion salisilat, triklorasetat, piktrat, tanat dan sulfosalisilat.

C. Denaturasi karena Asam dan basa

Protein akan mengalami kekeruhan terbesar pada saat mencapai titik isoelektrik, pada saat inilah protein mengalami denaturasi yang ditandai kekeruhan meningkat dan timbulnya gumpalan. Asam dan basa dapat memecahkan jembatan garam dengan adanya muatan ionik. Contonya reaksi yang terjadi di dalam sistem pencernaan, saat asam lambung mengkoagulasi susu yang dikonsumsi.

D. Perubahan $\mathrm{pH}$, contohnya susu yang berubah rasa menjadi asam.

E. Detergen

F. Radiasi

G. Zat Pengoksidasi atau pereduksi

H. Perubahan tipe pelarut

\subsection{Penyakit Yang Berhubungan dengan Protein}

\section{A. Marasmus}

Marasmus merupakan bentuk kekurangan gizi buruk, yang paling banyak ditemui pada bayi dibawah usia 12 bulan. Penyebabnya bisa terjadi karena kekurangan protein yang sering disertai dengan gejala kekurangan karbohidrat. Penyakit ini tentu cukup berbahaya jika diderita, sebab dapat menggiring penderitanya pada kematian. Ciri-ciri :

1. Berat badan kurang dari $60 \%$ dari berat badan yang seharusnya.

2. Suhu tubuh menjadi rendah.

3. Kulit di tubuh melonggar dan mengkerut sehingga bentuk tulang sangat nampak. 
4. Berwajah lonjong dan tampak lebih tua.

5. Perut berbentuk cekung yang biasa disertai dengan diare.

6. Kehilangan nafsu makan.

\section{B. Kwashiorkor}

Penyakit kwashiorkor ini merupakan penyakit yang bisa terjadi akibat kekurangan protein. Berbeda dengan marasmus, penyakit ini paling banyak ditemukan pada anakanak usia 1 hingga 3 tahun. Apabila pada marasmus tubuh penderitanya cenderung kurus, maka pada kwashiorkor penampilan dari penderita terlihat normal.

Walaupun begitu, penyakit ini harus diwaspadai sebab jika tidak maka anak-anak pertumbuhannya akan terhambat bahkan bisa mengalami cacat mental, seperti ADHD pada anak. Ciri-ciri :

1. Mengalami kelelahan yang tinggi

2. Terjadi pembengkakan pada perut, juga pada punggung kaki dan tangan

3. Sering mengalami diare

4. Berwajah bulat

5. Pandangan mata sayu

6. Rambut menjadi kusam, tipis hingga kemerahan dan gampang dicabut

7. Kehilangan nafsu makan dan gampang rewel

8. Hati berlemak dan membesar

9. Kekeringan pada kulit hingga bersisik dan pecah-pecah

10. Luka sulit untuk sembuh

11. Sering disertai dengan infeksi yang akut

12. Anemia dan xeroftalmia 


\section{Cachexia}

Penyakit cachexia merupakan penyakit yang menyerang seseorang akibat kekurangan protein. Penyakit ini dapat menyebabkan penurunan berat badan, penyakit kanker, gagal ginjal, penyakit menular AIDS, bahkan kematian apabila tidak ditangani dengan baik. Ciri-ciri :

1. Kerap merasa lelah walaupun hanya beraktifitas ringan.

2. Menipisnya otot rangka.

3. Terjadinya degradasi protein.

4. Berat badan menurun secara yang ekstrim.

\section{Gagal Hati}

Gagal hati adalah merupakan penyakit yang menyebabkan kerusakan dan kehilangan fungsi hati akibat ketidakmampuan sel hati untuk beregenerasi. Hal ini juga menjadi penyakit akibat kekurangan protein. Karena menimbulkan hal yang membahayakan, maka kondisi ini sangat memerlukan penanganan medis. Ciri-ciri :

1. Merasa mual

2. Nafsu makan menghilang

3. Sering mengalami rasa lelah

4. Kulit dan mata menguning jika telah mencapai tahap akut

5. Pembengkakan pada perut

6. Mengalami diare

7. Gampang memar dan berdarah

E. Apati

Definisi dari apati yaitu suatu kondisi yang menyebabkan emosi menjadi tumpul. Efek penyakit akibat 
kekurangan protein ini, bisa mempengaruhi tingkah laku dan fungsi kognitif. Biasanya, apati sering disertai dengan depresi. Namun, kedua hal ini berbeda. Jika depresi berupa gangguan emosi, maka apati berupa gangguan motivasi. Ciri-ciri :

1. Kurangnya usaha sehingga sering bergantung pada orang lain

2. Tidak ada keinginan untuk belajar hal-hal baru

3. Kurang peduli terhadap masalah

4. Fluktuasi emosi tidak terjadi

5. Kurangnya respon terhadap suatu peristiwa atau kejadian

\section{F. Edema}

Penyakit edema ini merupakan nama lain dari retensi air, yakni penyakit kekurangan protein yang paling sering diderita manusia. Jika darah yang mengalir pada tubuh tidak memiliki protein yang cukup, maka seseorang bisa mengalami gejala tekanan darah rendah sehingga gampang pusing, lemas dan malas beraktifitas.

Akibatnya, genre darah yang tidak mengandung protein dapat membentuk jaringan pada sekitar pembuluh darah yang mirip dengan gumpalan air. Jaringan inilah yang biasa disebut dengan edema. Ciri-ciri :

1. Pembengkakan pada kulit dan kadang terasa kenyal

2. Kadang disertai nyeri atau tidak

3. Kadang disertai demam atau tidak 


\section{G. Rambut Rontok}

Rambut yang rontok secara tidak normal bisa terjadi akibat tubuh kekurangan protein. Ketika ratusan helai rambut mengalami kerontokan tiap harinya, maka ini merupakan tanda bahwa seseorang sedang mengalami penyakit rambut rontok. Hal ini tentu saja tidak bisa dianggap sepele, sebab lama-kelamaan dapat membuat kepala menjadi botak, bahkan sulit untuk tumbuh kembali. Ciri-ciri :

1. Rambut mudah lepas saat menyisir ataupun saat keramas

2. Banyak rambut berguguran saat bangun tidur

3. Banyaknya rambut yang menempel pada baju yang dikenakan

\section{H. Gangguan Otak}

Otak merupakan pusat saraf manusia agar dapat berpikir serta mampu menggerakkan tubuh. Jika seseorang kekurangan protein, maka kecepatan berpikir orang tersebut akan menjadi rendah bahkan sehingga bisa mengakibatkan gangguan yang parah atau fatal. Misalnya saja seperti berkurangnya kecepatan motorik, mudah stres atau depresi, dan lainnya.

\section{Penyakit Jantung}

Jantung yang berdetak dalam tubuh manusia ternyata sangat membutuhkan protein. Sebab, jika tubuh seseorang kekurangan protein, maka denyut jantung yang bisa dihasilkan sangat rendah yaitu dibawah 60 kali denyutan dalam satu menit. Ciri-ciri :

1. Sering mengalami sesak nafas 
2. Biasa mengalami gejala batuk

3. Nafsu makan menjadi berkurang

4. Gampang lelah atau lemas

\section{J. Kelelahan}

Tubuh yang sering mengalami kelelahan merupakan salah satu tanda bahwa seseorang kekurangan protein. Jika protein ini tidak cukup untuk tubuh, maka jaringan otot yang mengalami kelelahan bisa rusak sehingga tidak dapat melakukan regenerasi.

Adapun beberapa hal membahayakan yang ditimbulkan oleh kelelahan ini seperti kram, rheumatik dan lainnya. Ciri-ciri :

1. Gampang merasa resah.

2. Sering jatuh tertidur saat sedang duduk atau saat melakukan aktifitas.

3. Merasa kurang keseimbangan pada tubuh.

4. Mudah marah.

5. Sulit berkonsentrasi.

\section{K. Ginjal}

Kelebihan protein pada tubuh, dapat menyebabkan seseorang mengalami gagal ginjal. Sebab, mengkonsumsi protein yang berlebih, maka akan membuat ginjal terpaksa bekerja lebih ekstra untuk membuang semua kelebihan nitrogen pada tubuh dan akhirnya membuat seseorang mengalami gagal ginjal. Selain itu, jika hal ini terjadi, maka akan mengakibatkan kadar urea menjadi tinggi, sehingga bisa menyebabkan masalah asam urat. 
Ciri-ciri:

1. Kepala terasa pusing hingga sulit untuk berkonsentrasi

2. Merasa gatal sehingga meninggalkan ruam pada tubuh

3. Merasa kedinginan pada tubuh

4. Mengalami sesak nafas

5. Merasa sakit pada daerah sekitar pinggang

\section{Pengasaman Darah}

Penyakit pengasaman darah bisa terjadi akibat kelebihan protein yang juga disertai dengan hilangnya elektron. Penyakit ini juga dapat membuat sistem imun tubuh menjadi melemah sehingga tubuh akan gampang terserang penyakit dan sulit untuk disembuhkan.

\section{Osteoporosis}

Mengkonsumsi protein secara berlebihan ternyata dapat menyebabkan kalsium berkurang. Jika hal ini terjadi, maka tubuh bisa mengambil kalsium dari gigi dan tulang agar keseimbangan tubuh tetap terjaga. Namun walaupun tubuh memiliki banyak kalsium dalam tubuh, akan tetapi tubuh sulit untuk menyerap senyawa yang dapat membentuk kalsium fosfat. Sehingga, kurangnya kalsium yang diserap oleh tubuh mengakibatkan seseorang rentan terhadap osteoporosis. Ciri-ciri:

1. Tinggi badan menjadi berkurang.

2. Sering mengalami nyeri pada sekitar punggung secara tiba-tiba.

3. Tulang jadi rapuh atau patah.

4. Mengalami perubahan struktur bentuk tubuh 


\section{N. PKU (Fenilketonuria)}

PKU artinya Fenil keton dalam urin. Penyakit ini tidak memiliki enzim fenilalanina hidroksilasi yang diperlukan untuk pengubahan ini. Pada penderita PKU fenilalanin diubah menjadi asam fenilpiruvat. Makanan penderita PKU harus mengandung tirosina dan sedikit fenilalanin, jika makanan mengandung asam fenilpiruvat berlebihan akan menumpuk pada otak dan menimbulkan keterbelakangan mental.

\subsection{Identifikasi Protein}

\section{A. Uji Kualitatif}

Analisa protein secara kualitatif bertujuan

1. Mengetahui adanya ikatan peptida dari suatu protein

2. Membuktikan adanya asam amino bebas dalam suatu protein

3. Membuktikan adanya asam amino yang memiliki struktur benzene

4. Mengetahui kelarutan protein terhadap suatu pelarut tertentu

5. Mengetahui titik isoelektrik dari suatu protein

\section{a. Uji Biuret}

Pada uji biuret, ion $\mathrm{Cu}^{2+}$ dari pereaksi biuret dalam suasana basa akan bereaksi dengan polipeptida atau ikatan peptida sehingga membentuk senyawa kompleks berwarna ungu atau violet. Reaksi ini positif terhadap dua buah ikatan peptida atau lebih, tetapi negatif untuk asam amino bebas atau dipeptida.

Biuret terdiri dari campuran larutan $\mathrm{NaOH} 0,1 \mathrm{M}$ dan larutan CuSO4 1\%. Larutan biuret digunakan untuk 
mengetahui adanya ikatan peptida pada suatu senyawa. Jika dalam senyawa yang diuji banyak terdapat ikatan peptida, maka dengan uji biuret akan memberikan warna ungu, misalnya protein. Jika senyawa yang diuji mengandung ikatan peptida sedikit, maka dengan uji biuret akan memberikan warna merah muda, misalnya urea.

\section{b. Uji Xantoproteat}

Uji xantoproteat terdiri dari campuran larutan $\mathrm{HNO}_{3}$ pekat atau campuran larutan asam cuka pekat dengan asam sulfat pekat lalu dipanaskan. Uji ini digunakan untuk mengetahui adanya cincin benzena dalam molekul protein. Protein yang mengandung cincin benzena jika dipanaskan dengan larutan $\mathrm{HNO}_{3}$ pekat akan memberikan warna kuning atau jingga.

Pada albumin dan triptofan mengindikasikan keduanya terdapat rantai cincin benzena, yaitu dengan terbentuknya lapisan jingga atau kuning jingga sedangkan pada kasein dan gelatin menghasilkan lapisan merah dan bening, mengindikasikan negatif atau tidak terdapat cincin benzena

\section{c. Uji Millon}

Uji Millon dilakukan dengan menambahkan pereaksi Millon yang mengandung $\mathrm{Hg}\left(\mathrm{NO}_{3}\right)_{2}$ dan $\mathrm{HNO}_{2}$. Uji Millon bereaksi positif dengan senyawa yang mengandung cincin benzena.

\section{d. Uji Timbel Sulfida}

Larutan yang digunakan pada uji timbal sulfida terdiri dari larutan $\mathrm{NaOH} 40 \%$ dan laruan $\mathrm{Pb}\left(\mathrm{NO}_{3}\right)_{2}$ atau $\mathrm{Pb}$-asetat. 
Larutan tersebut digunakan untuk mengetahui adanya unsur belerang dalam suatu protein. Protein yang mengandung belerang jika dipanaskan dengan larutan $\mathrm{NaOH} 40 \%$ akan menghasilkan $\mathrm{Na}_{2} \mathrm{~S}$ dan zat lain. Kemudian, ditetesi dengan $\mathrm{Pb}\left(\mathrm{NO}_{3}\right)_{2}$ atau $\mathrm{Pb}$-asetat yang akan memberikan warna cokelat sampai hitam dari PbS terbentuk.

\section{e. Uji Ninhidrin}

Uji ninhidrin dapat digunakan untuk menentukan asam amino secara kuantitatif. Semua asam amino atau peptida yang mengandung asam- $\alpha$ amino bebas akan bereaksi dengan ninhidrin membentuk senyawa kompleks berwarna biru-ungu. Namun, prolin dan hidroksiprolin menghasilkan senyawa berwarna kuning.

Albumin, gelatin, dan fenilalanina membentuk warna ungu karena dapat bereaksi dengan Ninhidrin. Hal ini menandakan ketiga zat uji tersebut mempunyai gugus asam amino bebas.

Pada kasein dan pepton jika direaksikan dengan ninhidrin tidak menghasilkan warna ungu melainkan hasilnya tidak berwarna sampai membentuk warna merah muda

\section{f. Uji Kelarutan Protein}

Daya larut protein berbeda di dalam air, asam, dan basa; ada yang mudah larut dan ada yang sukar larut. Namun, semua protein tidak larut dalam pelarut lemak seperti eter dan kloroform. Apabila protein dipanaskan atau ditambah etanol absolut, maka protein akan menggumpal 
(terkoagulasi). Hal ini disebabkan etanol menarik mantel air yang melingkupi molekul-molekul protein.

Kelarutan protein di dalam suatu cairan, sangat dipengaruhi oleh beberapa faktor antara lain, $\mathrm{pH}$, suhu, kekuatan ionik dan konstanta dielektrik pelarutnya. Protein seperti albumin dan gelatin tidak larut hanya pada $\mathrm{NaOH}$ $40 \%$ dan kloroform karena albumin dan gelatin adalah pelarut lemak.

\section{B. Uji kuantitatif}

\section{Metode Kjeldahl}

Unsur nitrogen pada protein dapat ditentukan secara kuantitatif dengan metode kjeldahl yaitu metode dengan cara dekstruksi dengan asam pekat. 


\section{RANGKUMAN}

1. Asam amino adalah suatu senyawa yang mengandung gugus amino dan gugus karboksil pada atom $C$ yang sama yaitu $C-\alpha$.

2. Asam amino terdiri dari 20 macam dan mempunyai fungsi yang berbeda-beda.

3. Klasifikasi asam amino berdasarkan rantai samping, asam amino esensial dan asam amino non esensial.

4. Peptida adalah suatu amida yang dibentuk dari dua asam amino atau lebih.

5. Ikatan peptida adalah ikatan amida antara suatu gugus $\alpha$ amino dari suatu asam amino dan gugus karboksil dari asam amino lain.

6. Protein adalah senyawa organik komplek berbobot molekul besar yang terdiri dari asam amino yang dihubungkan satu sama lain dengan ikatan peptida.

7. Fungsi protein antara lain :

a. Sebagai pertumbuhan dan pemeliharaan tubuh.

b. Pembentukan senyawa-senyawa penting tubuh

c. Pembentuk antibodi tubuh

d. Berperan dalam pengangkutan zat-zat gizi

e. Sumber energi

f. Mengganti Sel yang Rusak

g. Sebagai Pembawa Materi Genetika

8. Klasifikasi protein berdasarkan bentuk, kelarutan, fungsi biologi, sumber, hasil hidrolisa.

9. Struktur protein dibagi menjadi :
a. Struktur primer
b. Struktur sekunder
c. Struktur tersier
d. Struktur kuartener 
10. Denaturasi adalah hilangnya sifat-sifat struktur lebih tinggi karena terpecahnya ikatan hidrogen, interaksi hidrofobik, ikatan garam dan terbukanya lipatan molekul protein sehingga hilangnya sifat biologis protein tersebut.

11. Penyakit yang berhubungan dengan protein antara lain:
a. Marasmus
b. Kwashiorkor
c. Cachexia
d. Gagal hati
e. Apati
f. Edema
g. Rambut rontok
h. Penyakit jantung
i. Kelelahan
j. Ginjal
k. Pengasaman darah
I. Osteoporosis

m. PKU atau Fenil keton dalam urin

12. Identifikasi Protein

a. Uji Kualitatif

i. Uji Biuret

ii. Uji xantoproteat

iii. Uji Millon

iv. Uji Timbel Sulfida

v. Uji Ninhidrin

vi. Uji Kelarutan Protein

b. Uji kuantitatif

Metode Kjeldahl 


\section{LATIHAN SOAL}

I. Isilah Jawaban Dibawah ini!

Asam amino larut dalam (1)... dan (2).... tetapi tidak larut dalam (3)..... Asam amino bersifat (4).... dibandingkan asam karboksilat dan bersifat basa dibandingkan (5).......

Berdasarkan rantai samping, Asam amino alifatik antara lain (6)..... (7)...... Asam amino mengandung gugus amida yaitu (8).......

Berdasarkan bentuknya protein dibedakan menjadi (9).... dan (10).....

Faktor-faktor penyebab denaturasi adalah (11)... (12).... (13).... (14)..... dan (15).............

Penyakit yang berhubungan dengan protein antara lain (16)... (17).... (18).......

Analisa protein secara kualitatif bertujuan untuk (19)...... (20)

\section{Pilihlah Jawaban yang Benar!}

1. Suatu asam amino mengalami reaksi asam-basa internal yang menghasilkan suatu ion dipolar disebut?
a. Momen dipol
c. Gaya tarik menarik
b. zwitterion
d. Kelarutan

2. Asam amino bersifat asam jika mengandung rantai samping $R$ ?
a. Gugus amino
c. Gugus $\mathrm{OH}$
b. Gugus SH
d. Gugus karboksil

3. Asam amino bersifat amfoter karena mengandung gugus?
a. Gugus karboksil
c. Gugus $\mathrm{OH}$
b. Gugus SH
d. Gugus N 
4. Membantu dalam meningkatkan daya memori dan juga membantu untuk menjaga sistem saraf yang sehat adalah fungsi dari asam amino?
a. Tryptophan
c. Valin
b. Isoleusin
d. Fenilalanin

5. Fungsi Asam aspartat adalah
a. Membantu. sintesis asam amino lainnya
b. Membantu dalam formasi purin dan pirimidin untuk sintesis DNA
c. Membantu dalam produksi hormon T3 dan T4 tiroid
d. Membantu dalam regenerasi kulit baru

\section{Cocokan Jawaban Berikut ini!}

1. Asam amino bersifat basa jika mengandung rantai samping $R$ ?

2. Salah satu fungsi asam amino adalah

3. Suatu amida yang dibentuk dari dua asam amino atau lebih disebut

4. Ikatan yang menghubungkan antara amida suatu gugus $\alpha$-amino dari suatu asam amino dan gugus karboksil dari asam amino lain disebut....

5. Contoh protein berdasarkan kelarutan yaitu

\section{Pilihan Jawaban :}
A. Penyusun protein
B. Gugus amino
C. Ikatan Peptida
D. Histon
E. Peptida 


\section{Benar atau Salah Pernyataan Dibawah ini!}

1. Titik lebur asam amino lebih tinggi dibanding dengan asam karboksilat atau amina (B / S)

2. pKa suatu asam amino berasal dari $-\mathrm{NH}_{3}{ }^{+}$sedangkan $\mathrm{pKb}$ berasal dari $-\mathrm{CO}_{2}^{-}$yang bersifat basa sangat lemah (B / S)

3. Asam amino bersifat ionik, artinya dapat bereaksi dengan larutan asam ataupun basa dan menghasilkan suatu kation atau anion (B / S)

4. Protein adalah senyawa organik komplek berbobot molekul besar yang terdiri dari asam amino dan dihubungkan dengan ikatan peptida (B / S)

5. Uji Millon digunakan untuk mengetahui adanya cincin benzena dalam molekul protein (B / S)

\section{Jelaskan Pertanyaan dibawah ini!}

1. Gambarlah struktur komponen dasar penyusun protein!

2. Apa yang anda ketahui tentang Titik isoelektrik (pl)?

3. Sebutkan masing-masing lima macam asam amino esensial dan asam amino nonesensial!

4. Sebutkan 5 fungsi protein!

5. Jelaskan tentang klasifikasi protein!

6. Jelaskan tentang struktur protein!

7. a. Apakah yang dimaksud denaturasi protein? Sebutkan hal-hal yang menyebabkan terjadinya denaturasi protein!

b. Jelasan tentang renaturasi protein secara singkat!

8. Mengapa kelebihan $\mathrm{CuSO}_{4}$ harus dihindari dalam uji biuret?

9. Mengapa telur yang semula cair setelah direbus menjadi padat dan berwarna putih susu ?

10. Bagaimanakah cara mengidentifikasi adanya protein dalam bahan makanan? 


\section{BAB IV}

\section{LIPID}

\begin{tabular}{|l|l|}
\hline Tujuan Instruksional & Materi \\
\hline Mahasiswa memahami & 4.1 Pendahuluan \\
tentang lipid sehingga & 4.2 Fungsi Lipid \\
dapat diterapkan dalam & 4.3 Klasifikasi Lipid \\
bidang kesehatan sesuai & 4.4 Reaksi-Reaksi Pada Lipid \\
dengan perkembangan & 4.5 Penyakit Yang Berhubungan \\
sains dan teknologi. & dengan Lipid \\
& 4.6 Identifikasi Lipid \\
\hline
\end{tabular}

\subsection{Pendahuluan}

Lipid atau lemak didefinisikan sebagai biomolekul turunan hidrokarbon yang mengandung satu gugus ester. Lipid atau lemak merupakan senyawa organik yang terdapat dalam alam, tak larut dalam air tetapi larut dalam pelarut organik non polar seperti dietil eter, etanol,metanol, eter, kloroform, dan benzene. Lipid atau lemak larut dalam pelarut organik non polar karena mempunyai polaritas yang sama dengan pelarut tersebut. 


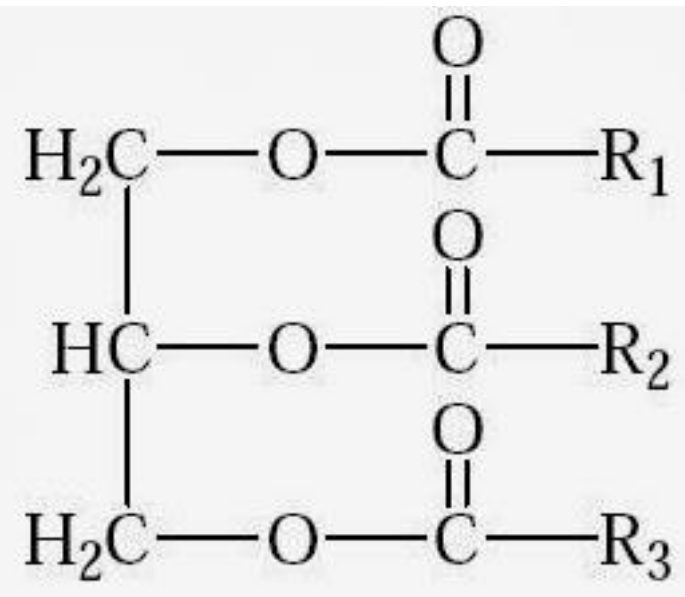

Gambar 4.1 Struktur umum lemak dengan $R_{1}, R_{2}, R_{3}$ dapat sama atau berbeda (Fessenden,1986)

Lipid banyak terdapat pada jaringan syaraf dan otak.Lipid atau lemak yang beredar di dalam tubuh diperoleh dari dua sumber yaitu dari makanan dan hasil produksi organ hati, yang biasadisimpan di dalam sel-sel lemak sebagai cadangan makanan. Lipid atau lemak memiliki kandungan energi tinggi. Lipid atau Lemak murni tidak berwarna, mereka memiliki rasa yang sangat hambar. Titik leleh Lipid atau Lemak tergantung pada panjang rantai asam lemak penyusun dan tingkat kejenuhan. Ketengikan hidrolitik Lipid atau lemak disebabkan oleh pertumbuhan mikroorganisme.

\subsection{Fungsi Lipid}

A. Sumber energi yang efisien secara langsung dan secara potensial bila disimpan dalam jaringan adiposa. 
B. Mengisi struktur tubuh dibawah kulit dan memperindah bentuk tubuh terutama pada wanita, seperti di sekitar organ-organ tubuh yang halus, lunak, vital dan mengisi rongga-rongga yang kosong

C. Sebagai isolator tubuhterhadap perubahan suhu maupun benturan.

D. Menjadi cadangan energi dalam bentuk sel lemak.

E. Lemak mempunyai fungsi selular dan komponen struktural pada membran sel yang berkaitan dengan karbohidrat dan protein demi menjalankan aliran air, ion dan molekul lain yang keluar dan masuk ke dalam sel

F. Lipid dapat berguna sebagai penyerap dan pembawa vitamin A, D, E dan K.

G. Sebagai hormon dan vitamin. Hormon mengatur komunikasi antar sel, sedangkan vitamin membantu regulasi prosesproses biologis

H. Lipid sebagai sumber steroid, yang sifatnya meningkatkan fungsi-fungsi biologisyang penting Contoh : Sterol (kolesterol) dilibatkan dalam sistem pemeliharaan membran, untuk transpor lipid dan sebagai prekursor vitamin D3 asam empedu, adrenal dan kortikosteroid.

I. Dari aspek teknologi makanan, lipid bertindak sebagai pelicin makanan yang berbentuk pellet, sebagai zat yang mereduksi kotoran dalam makanan dan berperan dalam kelezatan makanan.

\subsection{Klasifkasi Lipid}

Lipid diklasifikasikan menjadi :

\section{A. Berdasarkan Struktur Kimia}

1. Lipid sederhana atau Homolipid 
Lipid sederhana atau Homolipid adalah lipid atau lemak yang tersusun atas asam lemak sejenis. Contohnya gliseril tripalmitat, gliseril tristearat, lilin,

\section{$\mathrm{H}_{2} \mathrm{C}-\mathrm{O}-\mathrm{CO}-\mathrm{C}_{15} \mathrm{H}_{31}$ \\ 1 \\ $\mathrm{HC}-\mathrm{O}-\mathrm{CO}-\mathrm{C}_{15} \mathrm{H}_{31}$ \\ I \\ $\mathrm{H}_{2} \mathrm{C}-\mathrm{O}-\mathrm{CO}-\mathrm{C}_{15} \mathrm{H}_{31}$}

Gambar 4.2 Struktur Gliseril Tripalmitat (Fessenden,1986)

2. Lemak majemuk (Campuran atau Heterolipid)

Lemak majemuk (Campuran atau Heterolipid) adalah tersusun atas asam lemak beda jenis, antara lain :

a. Fosfolipid

Fosfolipid adalah senyawa yang mengandung asam lemak, gliserol dan residu asam fosfat, serta mempunyai basa nitrogen. Fosfolipid bersifat amfifilik, yaitu memiliki gugus kepala (fosfat) yang bersifat hidrofil dan gugus ekor (lipid) yang bersifat hidrofob. Fosfolipid terdapat dalam sel tumbuhan/hewan. Contoh fosfolipid antara lain fosfolipid bilayer (membran sel). 


\section{hidrofilik,}

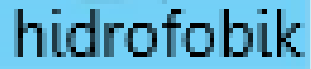

Gambar Contoh Fosfolipid (Harper, 1980)

Berdasarkan ester fosfatnya fosfolipid dibedakan menjadi :

\section{i. Asam fosfatidat}

Asam fosfatidat : Sebagai intermediat penting dalam sintesis triasilgliserol dan prekursor fosfatidilgliserol sehingga menghasilkan kardiolipin dalam mitokondria

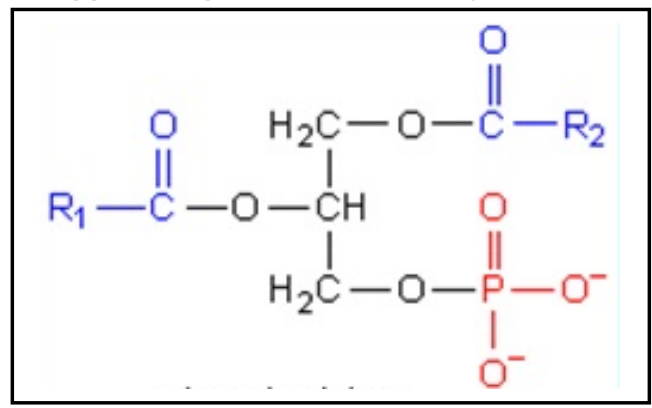

Gambar Struktur Asam Fosfatidat (Fessenden,1986)

ii. Fosfatidilkolin (lesitin)

Fosfatidilkolin (lesitin) : Sebagai pembawa asam amino kolin 


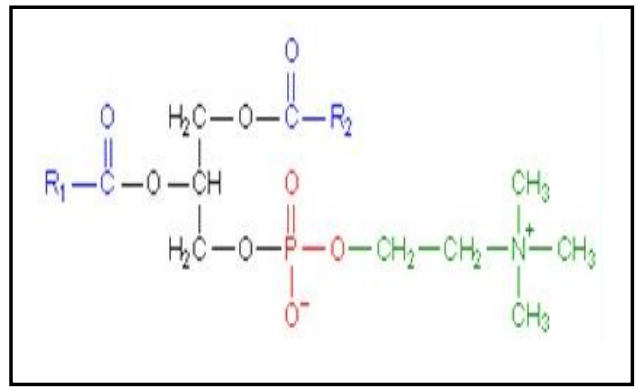

Gambar Struktur Fosfatidilkolin (lesitin) (Fessenden,1986)

iii. Fosfatidiletanolamin

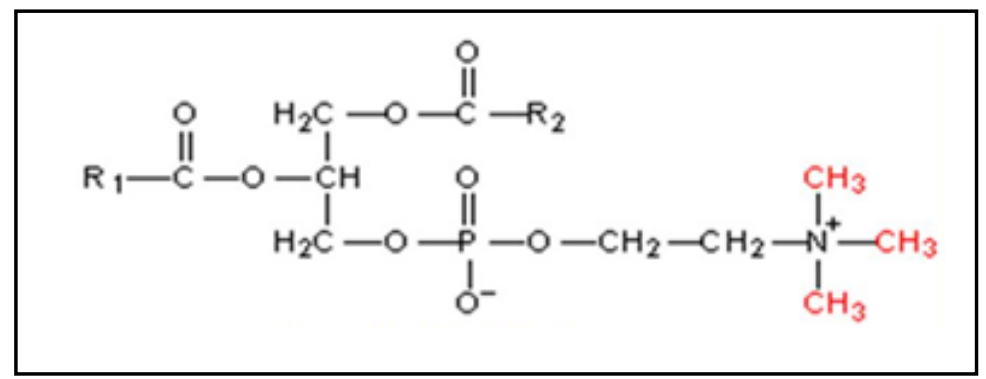

Gambar Struktur Fosfatidiletanolamin (Fessenden,1986) 
iv. Fosfatidilinositol

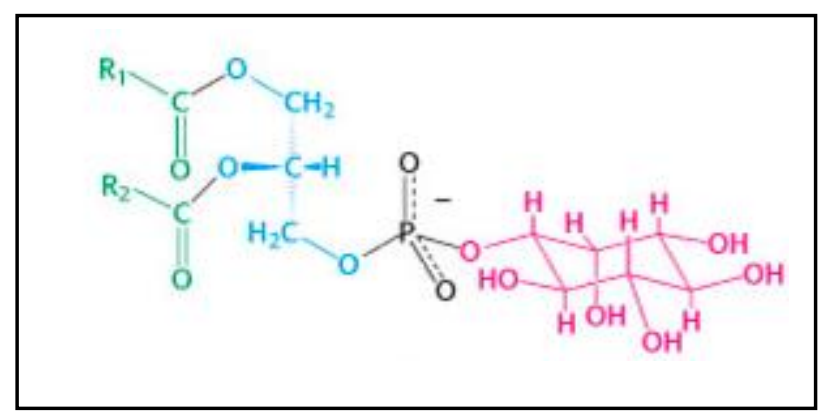

Gambar Struktur Fosfatidilinositol (Fessenden,1986)

v. Fosfatidilserin

Fosfatidilserin : Mengandung asam amino serin, sebagai pengganti etanolamin.

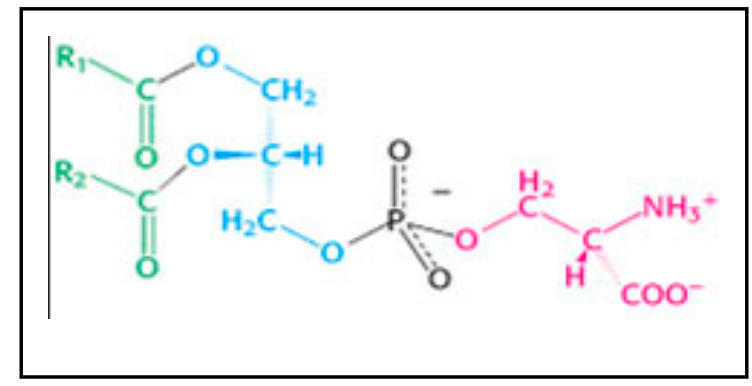

Gambar Struktur Fosfatidilserin(Fessenden,1986)) 
vi. Lisofosfolipid

Lisofosfolipid : Mengandung hanya satu radikal asil

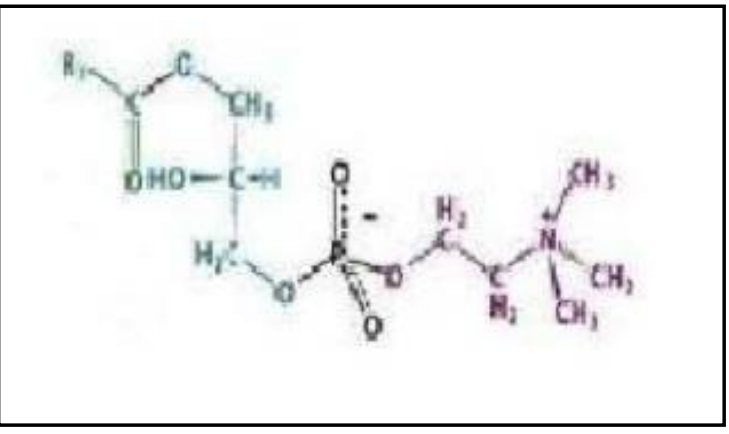

Gambar Struktur Lisofosfolipid (Fessenden,1986)

vii. Fosfogliserasetal

viii. Sfingomielin

Sfingomielin : Ditemukan dalam jumlah besar pada otak dan jaringan syaraf. Hidrolisis sfingomielin menghasilkan asam lemak, asam fosfat, kolin dan amino alkohol kompleks yaitu sfingosin.

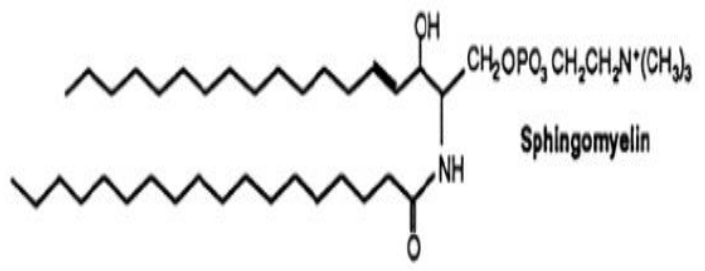

Gambar Struktur Sfingomielin(Fessenden,1986) 
b. Steroid

Steroid Adalah turunan lemak yang tidak mengandung gugus asam lemak dan gugus ester. Steroid bersifat amfifilik seperti fosfolipid, dan tersusun atas 4 cincin karbon dengan jumlah ikatan rangkap berbedabeda dan mengikat bermacam-macam gugus. Steroid tidak terhidrolisis pada pemanasan. Steroid tersebar luas pada hewan. Contoh steroid antara lain Estranes, androstranes, kolesterol, progesteron, estrogen dan testosteron.

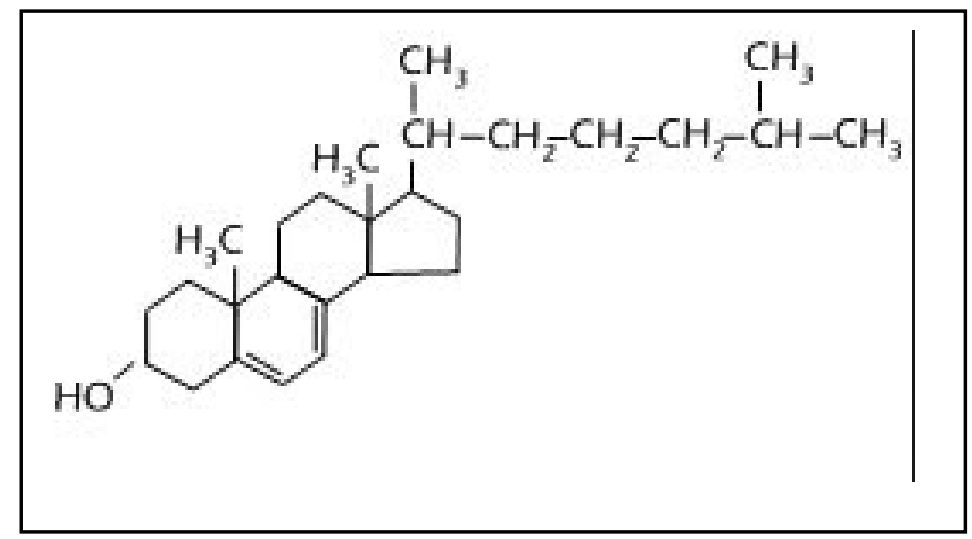

Gambar Kolesterol (Fessenden,1986)

c. Glikolipid

Glikolipid adalah senyawa asam lemak dengan karbohidrat dan mengandung nitrogen tetapi tidak mengandung asam fosfat. Contoh: Glikosil diasil gliserol yang terdapat dalam tanaman dan mikroorganisme. 


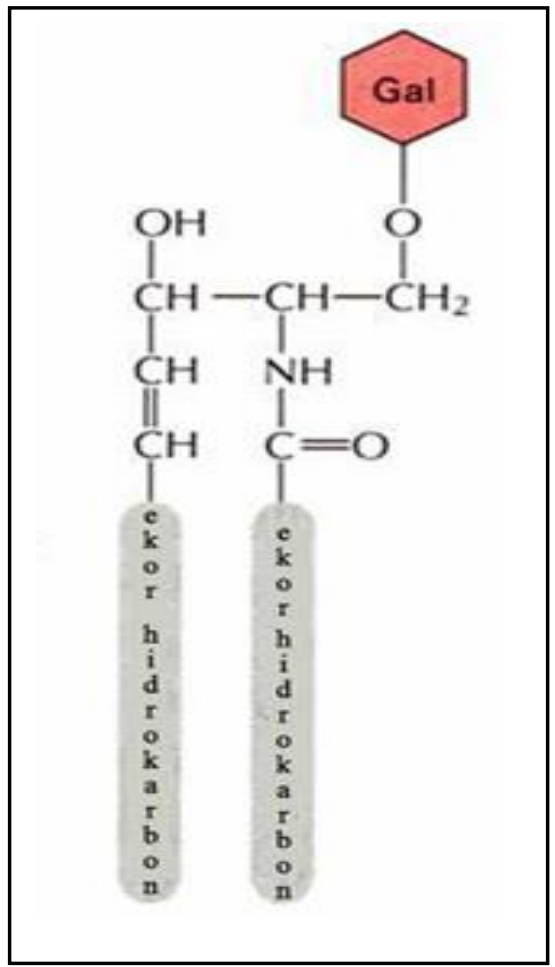

Gambar Struktur Glikolipid (Harper,1980)

\section{B. Berdasarkan Kejenuhannya (Ikatan Rangkap) :}

Asam lemak esensial adalah Asam lemak yang tidak dapat disintesis melalui jalur kimia dan diperoleh dari makanan. Contohnya Asam linoleat.Asam lemak non-esensial adalah Asam lemak yang dapat disintesis melalui jalur kimia. Asam lemak dibagi menjadi :

1. Asam Lemak Jenuh

Asam lemak jenuh adalah asam lemak yang tidak mengandung ikatan rangkap. 
2. Asam Lemak Tak Jenuh

Asam lemak tak jenuh adalah asam lemak yang mengandung ikatan rangkap dan dapat terjadi dalam konfigurasi cis atau trans.

Tabel 4.1 Tabel Asam Lemak (Fessenden,1986)

\begin{tabular}{|c|c|c|}
\hline Rumus Struktur & $\begin{array}{l}\text { Rumus } \\
\text { Molekul }\end{array}$ & $\begin{array}{c}\text { Nama Asam } \\
\text { Lemak }\end{array}$ \\
\hline \multicolumn{3}{|l|}{ a. Asam lemak jenuh: } \\
\hline $\mathrm{CH}_{3}\left(\mathrm{CH}_{2}\right)_{10} \mathrm{COOH}$ & $\mathrm{C}_{11} \mathrm{H}_{23} \mathrm{COOH}$ & Asam laurat \\
\hline $\mathrm{CH}_{3}\left(\mathrm{CH}^{2}\right)_{14} \mathrm{COOH}$ & $\mathrm{C}_{15} \mathrm{H}_{31} \mathrm{COOH}$ & Asam palmitat \\
\hline $\mathrm{CH}_{3}\left(\mathrm{CH}_{2}\right)_{16} \mathrm{COOH}$ & $\mathrm{C}_{12} \mathrm{H}_{35} \mathrm{COOH}$ & Asam stearat \\
\hline \multicolumn{3}{|l|}{ b. Asam lemak tak jenuh: } \\
\hline $\mathrm{CH}_{3}\left(\mathrm{CH}_{2}\right)_{7} \mathrm{CH}=\mathrm{CH}\left(\mathrm{CH}_{2}\right)_{2} \mathrm{COOH}$ & $\mathrm{C}_{1} \mathrm{H}_{33} \mathrm{COOH}$ & Asam oleat \\
\hline $\mathrm{CH}_{3}\left(\mathrm{CH}_{2}\right)_{4} \mathrm{CH}=\mathrm{CHCH}_{2} \mathrm{CH}=\mathrm{CH}\left(\mathrm{CH}_{2}\right), \mathrm{COOH}$ & $\mathrm{C}_{1,} \mathrm{H}_{31} \mathrm{COOH}$ & Asam linoleat \\
\hline $\mathrm{CH}_{3} \mathrm{CH}_{2} \mathrm{CH}=\mathrm{CHCH}_{2} \mathrm{CH}=\mathrm{CHCH}_{2} \mathrm{CH}=\mathrm{CH}\left(\mathrm{CH}_{2}\right)_{7} \mathrm{COOH}$ & $\mathrm{C}_{1}, \mathrm{H}_{2} \mathrm{COOH}$ & Asam linolenat \\
\hline
\end{tabular}

\section{Berdasarkan Sifat Mengering}

1. Minyak tidak mengering (non-drying oil), contohnya minyak zaitun, minyak biji rape, minyak hewani.

2. Minyak setengah mengering (semi-drying oil) minyak yang mempunyai daya mengering lebih lambat, contohnya minyak biji kapas, minyak bunga matahari.

3. Minyak nabati mengering (drying-oil) minyak yang dapat mengering jika terkena oksidasi akan berubah menjadi lapisan tebal, bersifat kental membentuk sejenis selaput jika dibiarkan di udara terbuka, contohnya minyak kacang kedelai, minyak biji karet. 


\section{Berdasarkan Sumbernya}

1. Berasal dari tanaman (minyak Nabati), contohnya minyak zaitun, minyak kelapa sawit

2. Berasal dari hewan(lemak hewani), contohnya minyak ikan sardin, minyak ikan paus

\section{E. Berdasarkan Kegunaannya}

1. Minyak meneral(minyak bumi) digunakan sebagai bahan bakar

2. Minyak nabati/hewani (minyak/lemak) digunakan sebagai bahan makan bagi manusia

3. Minyak atsiri(essential oil) digunakan untuk obat-obatan, minyak atsiri mudah menguap pada temperatur kamar.

\subsection{Reaksi-reaksi pada lipid :}

i. Reaksi Saponifikasi atau penyabunan

Reaksi Saponifikasi atau penyabunanadalah reaksi hidrolisis lemak/minyak dengan menggunakan basa kuat seperti $\mathrm{NaOH}$ atau $\mathrm{KOH}$ sehingga menghasilkan gliserol dan garam asam lemak atau sabun.Jenis-jenis sabun:

1. Sabun kerasadalah sabun yang terbentuk dari $\mathrm{NaOH}$. Contoh: sabun cuci.

2. Sabun lunakadalah sabun yang terbentuk dari $\mathrm{KOH}$. Contoh: sabun mandi. 


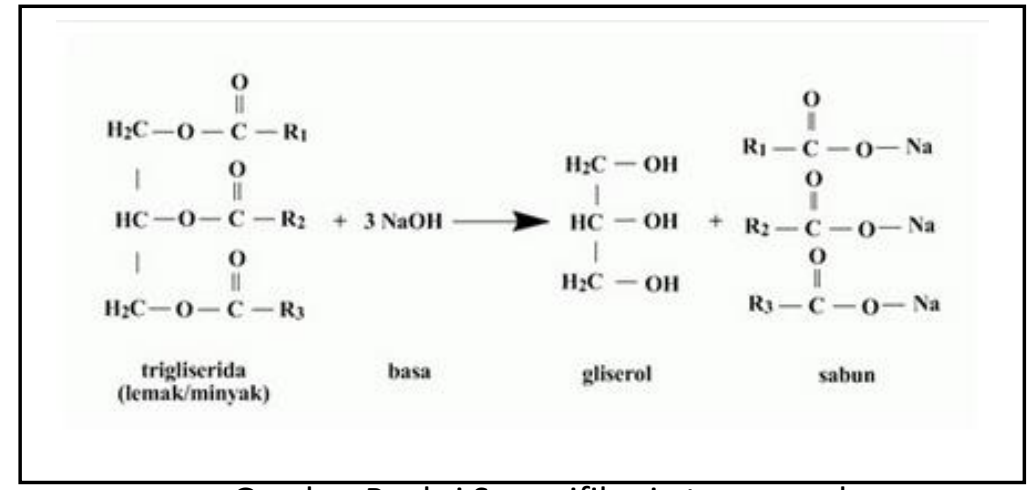

Gambar Reaksi Saponifikasi atau penyabunan

(Fessenden,1986)

ii. Reaksi Pembentukan

1. Reaksi Pembentukan Lemak

Asam Lemak + Gliserol $\rightarrow$ Lemak + Air

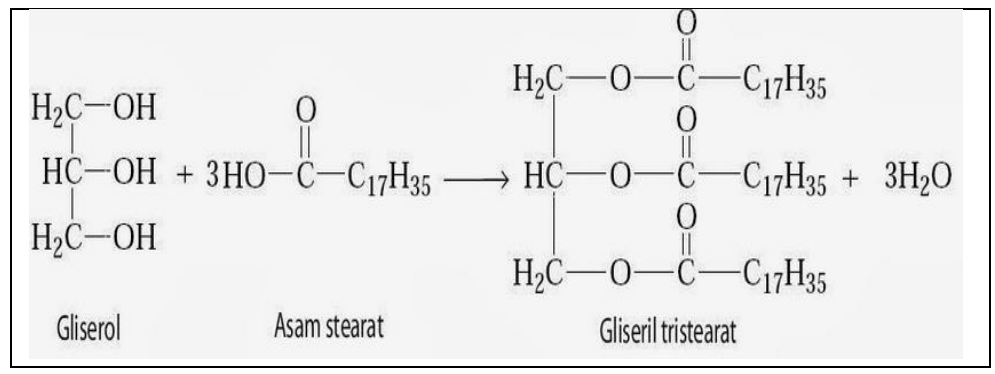

Gambar Contoh Reaksi Pembentukan Lemak (Fessenden,1999) 
2. Hidrolisis Lemak

Lemak + Air $\rightarrow$ Asam Lemak + Gliserol

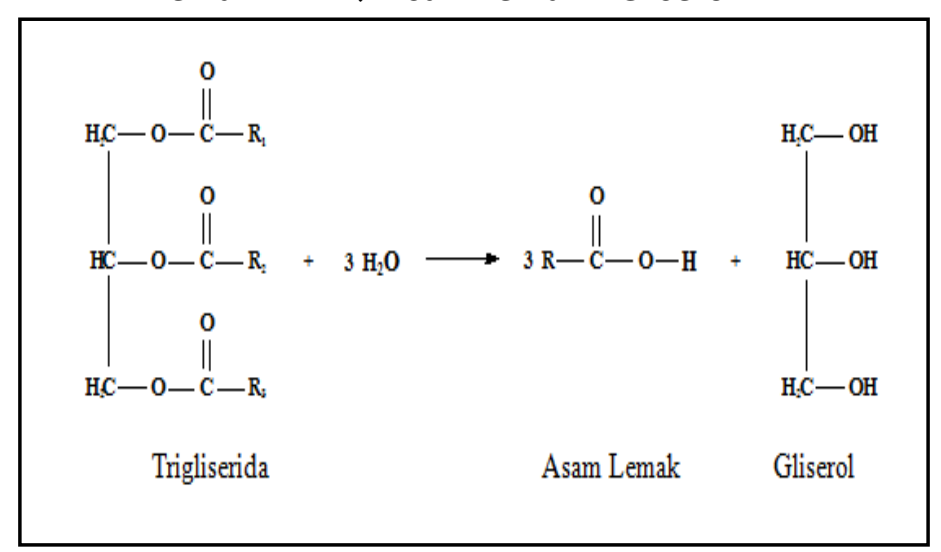

Gambar Reaksi Hidrolisis Lemak (Fessenden,1999)

\section{iii. Reaksi Hidrogenasi}

Reaksi hidrogenasi Adalah reaksi penjenuhan lemak yang mengubah wujud lemak menjadi padat dengan bantuan logam Platina $(\mathrm{Pt})$ atau Nikel $(\mathrm{Ni})$.

Lemak tak jenuh $+\mathrm{H}_{2} \rightarrow$ lemak jenuh

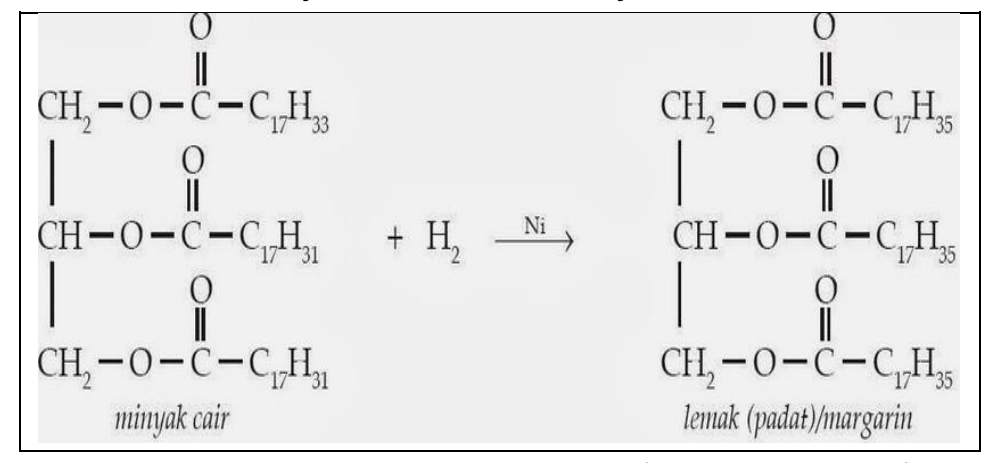

Gambar Contoh Reaksi Hidrogenasi (Fessenden,1986) 


\subsection{Penyakit Yang Berhubungan Dengan Lipid}

\section{A. Penyakit Kelebihan Lemak:}

1. Kolesterol Tinggi

Konsumsi bermacam-macam lemak secara berlebihan mampu membuat kadar kolesterol naik dengan cepat dan mudah di dalam tubuh. Inilah yang kemudian menjadi penyebab banyak penyakit serius, seperti penimbunan plak yang menghambat jalannya aliran darah di pembuluh darah, kerusakan arteri, serta pembuluh darah yang mengalami penyempitan. Semuanya itu adalah efek yang akan meningkatkan risiko penyakit jantung

2. Sembelit

Kandungan lemak yang tinggi di dalam makanan yang biasa dikonsumsi bisa berpengaruh buruk bagi sistem kerja organ di dalam tubuh. Efek yang akan paling terasa adalah saluran pencernaan yang menjadi kurang lancar, seperti pada perut dan usus. Sembelit adalah efek paling umum yang terjadi karena kelebihan lemak sehingga pencernaan terganggu.

3. Kerusakan pada Dinding Arteri

Mengonsumsi lemak yang jenuh secara berlebihan akan menjadi faktor peningkatan kadar kolesterol di dalam darah dan memberikan efek buruk bagi arteri jantung. Apabila arteri jantung mengalami kerusakan maka bagian organ tubuh lain akan rusak juga, seperti ginjal dan otak.

4. Obesitas

Kegemukan atau obesitas adalah efek yang paling identik dengan lemak berlebih di dalam tubuh, seperti lemak 
trans, lemak jenuh, lemak tak jenuh ganda maupun tunggal

5. Kerusakan Otak

Konsumsi makanan yang mengandung lemak secara berlebihan tak hanya memicu kerusakan arteri, tapi juga fungsi otak. Hipotalamus yang termasuk bagian pada organ otak dan bertugas membantu pengaturan keseimbangan energi akan dirusak oleh lemak jenuh yang masuk ke dalam tubuh dari makanan yang kita makan.

6. Meningkatkan Resiko Kanker

Pola makan yang tidak diatur dengan baik dapat mengakibatkan kanker. Lemak yang berlebihan di dalam tubuh dan tidak diimbangi dengan kandungan serat cukup akan memudahkan sel kanker untuk tumbuh di berbagai organ tubuh kita. Contoh 2 penyakit kanker yang dapat menyerang tubuh secara lebih gampang adalah leukimia dan kanker payudara.

\section{B. Penyakit Kekurangan Lemak}

1. Kekeringan pada Kulit

Ketika seseorang tak mencukupi kebutuhan lemak di dalam tubuhnya, kulit akan terkena efeknya akan menjadi kering dan kusam. Hal ini juga akan menurunkan rasa percaya diri, terutama bagi para wanita yang memedulikan penampilan. Kekeringan bisa terjadi pada kulit apabila tubuh tak memiliki cukup lemak, bahkan pada kulit juga akan muncul gatal-gatal serta sisik.

2. Sulit Fokus dan Konsentrasi

Lemak dibutuhkan oleh sistem otak supaya dapat berfungsi dengan baik, maka ketika tubuh tak mendapat 
cukup lemak, otak pun terkena imbasnya. Kekurangan lemak akan membuat seseorang sulit fokus pada suatu hal dan mustahil rasanya untuk berkonsentrasi dengan baik.

\section{Lemas dan Mudah Lelah}

sumber energi datangnya dari lemak selain dari protein serta karbohidrat, maka ketika lemak berkurang di dalam tubuh, tubuh akan kekurangan energi. Bila energi kurang, otomatis tubuh akan lemas dan mudah lelah.

\section{Kedinginan}

Orang yang memiliki lemak cukup tak akan mudah kedinginan, dan sebaliknya orang yang tak mencukupi kebutuhan lemak maka meski saat cuaca dan suhu tak begitu dingin akan lebih mudah merasa kedinginan.

\section{Ketidakstabilan Kadar Gula Darah}

Apabila kadar gula darah di dalam tubuh tak stabil dan cenderung tinggi, hal ini dikarenakan kurangnya lemak di dalam tubuh. Kadar gula darah yang cenderung tinggi dapat berpotensi diabetes sehingga sangat perlu untuk memeriksakan dan rajin mengecek kadar lemak dan gula darah ke dokter.

\subsection{Identifikasi Lipid}

\section{A. Uji Kualitatif Lemak}

Penentuan adanya lipida atau lemak dalam suatu bahan dapat dilakukan dengan berbagai macam analisa. Salah satunya adalah dengan menggunakan analisa kualitatif untuk menentukan adanya lipida atau tidak, antara lain : 
1. Uji Pengenalan Lemak :

a. Uji Kertas Buram

Dilakukan dengan meletakkan zat ke atas kertas buram. Uji kertas buram bereaksi positif dengan seluruh jenis lemak. Jika hasilnya positif maka kertas menjadi transparan, jika negatif maka kertas menjadi tidak transparan.

b. Uji Sudan III

Dilakukan dengan meneteskan pereaksi Sudan III berwarna merah. Pereaksi Sudan III bereaksi positif dengan seluruh jenis lemak. Jika hasilnya positif akan menghasilkan warna coklat, jika negatif hasilnya tidak berubah warna.

2. Uji Kelarutan Lipid

Uji ini dapatdigunakan untuk analisis kelarutan lipid maupun derivat lipid terdahadap berbagai macam pelarut. Dalam uji ini, kelarutan lipid ditentukan oleh sifat kepolaran pelarut. Apabila lipid dilarutkan ke dalam pelarut polar maka hasilnya tidak akan larut. Hal tersebut karena lipid memiliki sifat nonpolar sehingga hanya akan larut pada pelarut yang sama-sama nonpolar.

3. Uji Acrolein

Uji Acrolein terjadi dehidrasi gliserol dalam bentuk bebas atau dalam bentuk lemak/minyak menghasilkan aldehid akrilat atau akrolein. Uji akrolein digunakan untuk menguji keberadaan gliserin atau lemak. Ketika lemak dipanaskan setelah ditambahkan agen pendehidrasi $\left(\mathrm{KHSO}_{4}\right)$ yang akan menarik air, maka bagian gliserol akan terdehidrasi ke dalam bentuk aldehid tidak jenuh atau dikenal sebagai akrolein $(\mathrm{CH} 2=\mathrm{CHCHO})$ yang memiliki bau seperti lemak terbakar dan ditandai dengan asap putih. 
4. Uji Kejenuhan

Uji ketidakjenuhan digunakan untuk mengetahui asam lemak jenuh atau tidak jenuh dengan menggunakan pereaksi lod Huble. lod Huble digunakan sebagai indikator perubahan. Asam lemak yang diuji ditambah kloroform. Tabung dikocok sampai bahan larut. Setelah itu, tetes demi tetes pereaksi lod Huble dimasukkan ke dalam tabung sambil dikocok dan mengamati perubahan warna yang terjadi. Reaksi positif ketidakjenuhan asam lemak ditandai dengan timbulnya warna merah asam lemak, lalu warna kembali lagi ke warna awal kuning bening. Warna merah yang kembali pudar menandakan bahwa terdapat banyak ikatan rangkap pada rantai hidrokarbon asam lemak. Pada uji ketidakjenuhan, pereaksi iod huble akan mengoksidasi asam lemak yang mempunyai ikatan rangkap pada molekulnya menjadi berikatan tunggal. Warna merah muda yang hilang selama reaksi menunjukkan bahwa asam lemak tak jenuh telah mereduksi pereaksi iod huble.

5. Uji Ketengikan

Uji Ketengikan untuk mengidentifikasi lipid yang sudah tengik yang disebabkan oleh oksidasi lipid. Penentuan uji ketengikan antara lain :

a. Bilangan Peroksida

Bilangan peroksida ditentukan berdasarkan jumlah iodin yang dibebaskan setelah lemak atau minyak ditambahkan KI. Lemak direaksikan dengan KI dalam pelarut asam asetat dan kloroform dengan perbandingan (2:1), kemudian iodin yang berbentuk ditentukan dengan titrasi $\mathrm{Na}_{2} \mathrm{~S}_{2} \mathrm{O}_{3}$. 
b. Jumlah Karbonil

Jumlah karbonil ditentukan dengan uji Kreiss memakai pereaksi floroglusinol. Prinsip uji Kreiss yaitu reaksi kondensasi antara ephydrin-aldehida dengan floroglusinol, sehingga menghasilkan warna merah jambu.

c. Oksigen Aktif

Oksigen aktif dihitung dengan cara melewatkan udara pada lemak yang dipanaskan pada suhu tetap $100^{\circ} \mathrm{C}$. Kemudian diukur waktu yang diperlukan sampai dihasilkan 20 miliekuivalen peroksida. Cara ini sering dipakai untuk menentukan keadaan awal lemak dengan atau tanpa antioksidan.

d. Uji Asam Tiobarbiturat

Pada uji asam tiobarbiturat, lemak yang tengik akan bereaksi dengan asam tiobarbiturat menghasilkan warna merah. Intensitas warna menunjukkan derajat ketengikan.

e. Uji Oven Schaal

Uji Oven Schaal sering dilakukan pada industri biskuit. Bahan dimasukkan dalam gelas bersih dengan tutup yang agak longgar supaya udara masih bisa masuk kemudian dipanaskan sampai $65^{\circ} \mathrm{C}$. Lalu diukur bau dan rasanya.

6. Uji Salkowski Untuk Kolesterol

Uji Salkowski merupakan uji kualitatif yang dilakukan untuk mengidentifikasi keberadaan kolesterol. Kolesterol dilarutkan dengan kloroform anhidrat lalu dengan volume yang sama ditambahkan asam sulfat. Asam sulfat berfungsi sebagai pemutus ikatan ester lipid. Apabila pada sampel terdapat kolesterol, maka lapisan kolesterol di 
bagian atas menjadi berwarna merah dan asam sulfat terlihat berubah menjadi kuning dengan warna fluoresens hijau.

\section{B. Uji Kuantitatif Lemak}

1. Uji Bilangan Reichert Meisel (BRM)

BRM adalah jumlah $0,1 \mathrm{~N}$ basa yang di perlukan setiap 5 gram lemak untuk menetralkan asam-asam lemak yang mudah menguap pada destilasi, yaitu asam lemak yang mempunyai atom $\mathrm{C}_{6}$ dan $\mathrm{C}_{4}$ (kaproat dan butirat). Analisis ini banyak di gunakan untuk menganalisis pemalsuan mentega yang di campur minyak lain. Minyak BRM untuk mentega antara 24-34, lebih tinggi dari minyak lain.

2. Uji Bilangan Polenske (BP)

Uji Bilangan Polen untuk menentukan kadar asam lemak yang volatile, tetapi tidak larut dalam air, yaitu asam lemak yang mempunyai atom $\mathrm{C}_{8}-\mathrm{C}_{14}$. Bilangan polenske adalah jumlah millimeter $(\mathrm{ml}) 0,1 \mathrm{~N}$ alkali yang di perlukan untuk menetralkan asam lemak yang mempunyai atom $\mathrm{C}_{8}-\mathrm{C}_{14}$ dalam 5 gram sampel. BP juga dapat di gunakan untuk menguji pemalsuan terhadap mentega.

3. Uji Bilangan Kirschner Baru (NEW KIRSCHNER VALUE $=$ NKV) Bilangan Kirschner Baru adalah jumlah $\mathrm{ml}$ basa $0,1 \mathrm{~N}$ yang di perlukan setiap 5 gram lemak/minyak untuk menetralkan asam lemak volatile. Penentuan BKB di gunakan untuk membedakan margarine dan mentega, yaitu untuk mengetahui ada tidaknya pemalsuan. Distilat hasil penentuan $\mathrm{BKB}$ ditambah $\mathrm{Ag}_{2} \mathrm{SO}_{4}$, dan akan terbentuk gram perak yang larut dalam air, kemudian diasamkan dengan $\mathrm{H}_{2} \mathrm{SO}_{4}$ dan di distilasi. 
4. Uji Bilangan Penyabunan (BP)

Bilangan Penyabunan adalah jumlah mg $\mathrm{KOH}$ yang di butuhkan untuk menyabunkan 1 gram lemak. Untuk menetralkan 1 molekul gliserida di perlukan 3 molekul alkali.Apabila sejumlah sampel lemak disabunkan dengan larutan $\mathrm{KOH}$ berlebih dalam alkohol, maka $\mathrm{KOH}$ akan bereaksi dengan trigliserida, yaitu tiga molekul $\mathrm{KOH}$ bereaksi dengan satu molekul lemak. Larutan alkali yang tertinggal ditentukan dengan titrasi menggunakan $\mathrm{HCl}$ sehingga $\mathrm{KOH}$ yang bereaksi dapat diketahui.

Dalam penetapan bilangan penyabunan, biasanya larutan alkali yang digunakan adalah larutan $\mathrm{KOH}$, yang diukur dengan hati-hati kedalam tabung buret atau pipet.Bilangan penyabunan menunjukkan berat molekul lemak dan minyak secar kasar. Pada trigliserida dengan asam lemak rantai $C$ nya pendek akan di dapat BP yang lebih tinggi dari pada asam lemak dengan rantai $\mathrm{C}$ panjang. Mentega yang kadar butirat nya tinggi mmpunyai BP yang paling tinggi.

5. Uji Bilangan Hebner

Bilangan Hebner untuk menentukan jumlah asal lemak yang tidak larut dalam air. Lemak dengan BM yang tinggi akan mempunyai bilangan hebner yang rendah.Filtrate yang di peroleh dari uji bilangan penyabunan, di uapkan alkoholnya. Sabun di larutkan dalam air panas dan di tambah $\mathrm{HCl}$ pekat sehingga terbentuk asam lemak bebas. Bila campuran tersebut segera di dinginkan, di peroleh lapisan asam lemak yang tak larut dalam air. Lapisan ini di saring dan di timbang.

6. Uji Bilangan lodin

Bilangan lodin adalah gram iodine yang diserap oleh 100 gram lemak. $I_{2}$ akan mengadisi ikatan asam lemak tidak jenuh dalam bentuk bebas maupun dalam bentuk ester. 
Bilangan iodine tergantung pada jumlah asam lemak tidak jenuh dalam lemak. Lemak yang akan diperiksa dilarutkan dalam kloroform $\left(\mathrm{CCl}_{4}\right)$ kemudian ditambahkan larutan iodine berlebihan ( 0,1-0,5 gram) sisa iodine yang tidak bereaksi dititrasi dengan tiosulfatAda dua cara yang digunakan untuk mengukur bilangan iodine tersebut, yaitu :

a. Metode Hanus

Pada metode hanus menggunakan larutan iodine dalam asam asetat pekat dan iodium bromide . lodium bomida akan mempercepat reaksi.

b. Metode Wijs

Pada metode wijs menggunakan larutan iodine dalam asam asetat pekat danmengandung iodium klorida sebagai pemacu reaksi. Titik akhir titrasi kelebihan iodine diukur dengan hilangnya warna biru dari amylum iodine.

7. Uji Lieberman Buchard

Uji Lieberman Buchard merupakan uji kuantitatif untuk kolesterol. Prinsip uji Lieberman Buchard adalah mengidentifikasi adanya kolesterol dengan penambahan asam sulfat ke dalam campuran. Sebanyak 10 tetes asam asetat dilarutkan ke dalam larutan kolesterol dan kloroform (dari percobaan Salkowski). Setelah itu, asam sulfat pekat ditambahkan. Tabung dikocok perlahan dan dibiarkan beberapa menit. Mekanisme yang terjadi dalam uji ini adalah ketika asam sulfat ditambahkan ke dalam campuran yang berisi kolesterol, maka molekul air berpindah dari gugus $C_{3}$ kolesterol, kolesterol kemudian teroksidasi membentuk 3,5-kolestadiena. Produk ini dikonversi menjadi polimer yang mengandung kromofor yang menghasilkan warna hijau. Warna hijau ini menandakan hasil yang positif. Reaksi positif uji ini 
ditandai dengan adanya perubahan warna dari terbentuknya warna pink kemudian menjadi biru-ungu dan akhirnya menjadi hijau tua. 


\section{RANGKUMAN}

1. Lipid atau lemak didefinisikan sebagai biomolekul turunan hidrokarbon yang mengandung satu gugus ester.

2. Fungsi lipid antara lain :

a. Sumber energi

b. Mengisi struktur tubuh dibawah kulit dan memperindah bentuk tubuh

c. Sebagai isolator tubuhterhadap perubahan suhu maupun benturan.

d. Menjadi cadangan energi dalam bentuk sel lemak.

e. Lemak mempunyai fungsi selular dan komponen struktural pada membran sel yang berkaitan dengan karbohidrat dan protein demi menjalankan aliran air, ion dan molekul lain yang keluar dan masuk ke dalam sel

f. Lipid dapat berguna sebagai penyerap dan pembawa vitamin A, D, E dan K.

g. Sebagai hormon dan vitamin.

h. Lipid sebagai sumber steroid,

i. Sebagai pelicin makanan yang berbentuk pellet

3. Klasifikasi lipid berdasarkan struktur kimia, kejenuhannya (Ikatan Rangkap), sifat mengering, sumber dan kegunannya.

4. Reaksi-reaksi pada lipid antara lain :

a. Reaksi Saponifikasi atau penyabunan

b. Reaksi Pembentukan

c. Reaksi Hidrogenasi

5. Penyakit Yang Berhubungan Dengan Lipid antara lain :

a. Penyakit kelebihan lemak :

i. Kolesterol Tinggi 
ii. Sembelit

iii. Kerusakan Pada Dinding Arteri

iv. Obesitas

v. Kerusakan Otak

vi. Meningkatkan Resiko Kanker

b. Penyakit Kekurangan Lemak

i. Kekeringan Pada Kulit

ii. Sulit Fokus dan Konsentrasi

iii. Lemas dan Mudah lelah

iv. Kedinginan

v. Ketidakstabilan Kadar Gula Darah

6. Identifikasi Lipid

A. Uji Kualitatif Lemak

i. Uji Pengenalan Lemak

ii. Uji Kelarutan Lipid

iii. Uji Acrolein

iv. Uji Kejenuhan

v. Uji Ketengikan

vi. Uji Salkowski Untuk Kolesterol

B. Uji Kuantitatif Lemak

i. Uji Bilangan Reichert Meisel (BRM)

ii. Uji Bilangan Polenske (BP)

iii. Uji Bilangan Kirschner Baru

iv. Uji Bilangan Penyabunan (BP)

v. Uji Bilangan Hebner

vi. Uji Bilangan lodin

vii. Uji Lieberman Buchard 


\section{LATIHAN SOAL}

I. Isilah Jawaban Dibawah ini!

Lipid larut dalam (1).... dan tak larut dalam (2)......

Lemak majemuk tersusun atas beberapa jenis asam lemak seperti (3)..... (4)..... dan (5)....

Berdasarkn kejenuhannya lipid dibagi menjadi (6).... dan (7)...

Reaksi (8)....... adalah reaksi hidrolisis lemak/minyak dengan menggunakan basa kuat seperti $\mathrm{NaOH}$ atau $\mathrm{KOH}$ sehingga menghasilkan gliserol dan garam asam lemak. Berdasarkan bentuknya sabun dibedakan menjadi (9).. dan $(10) \ldots$

\section{Pilihlah Jawaban yang Benar!}

1. Lipid yang tersusun atas asam lemak sejenis disebut?
a. Heterolipid
c. Fosfolipid
b. Homolipid
d. Gliserol

2. Contoh asam lemak jenuh yaitu
a. Asam amino
c. Asam Nukleat
b. Asam Stearat
d. Asam Oleat

3. Contoh asam lemak tak jenuh yaitu
a. Asam amino
c. Asam Nukleat
b. Asam Stearat
d. Asam Oleat

4. Kegunaan minyak atsiri adalah
a. Sebagai bahan bakar
b. Sebagai obat-obatan
c. Sebagai pelarut
d. Sebagai bahan makanan

5. Fungsi lipid adalah

a. Pemanis buatan 

b. Penyerap dan pembawa vitamin A, D, E dan K.
c. Pembentuk otot
d. Pembawa DNA

\section{Cocokan Jawaban Berikut ini!}

1. Contoh lemak nabati adalah

2. Reaksi penjenuhan lemak yang mengubah wujud lemak menjadi padat dengan bantuan logam Platina disebut

3. Salah satu penyakit kelebihan lemak adalah

4. Salah satu penyakit kekurangan lemak adalah

5. Uji pengenalan lemak menggunakan.....

\section{Pilihan Jawaban :}
A. Reaksi Hidrogenasi
B. Kolesterol
C. Minyak Zaitun
D. Kertas buram
E. Kekeringan pada kulit

\section{Benar atau Salah Pernyataan Dibawah ini!}

1. Fungsi lemak sebagai isolator tubuht erhadap perubahan suhu maupun benturan (B / S)

2. Semi-drying oil minyak yang mempunyai daya mengering lebih lambat (B / S)

3. Hidrolisis lemak adalah reaksi persabunan (B / S)

4. Uji Acrolein terjadi dehidrasi gliserol dalam bentuk bebas atau dalam bentuk lemak/minyak menghasilkan aldehid akrilat atau akrolein (B / S)

5. Bilangan peroksida merupakan pengujian ketengikan terhadap lemak (B / S) 


\section{Jelaskan Pertanyaan dibawah ini!}

1. Sebutkan sifat fisik dan kimia lipid!

2. Jelaskan fungsi lipid untuk kehidupan?

3. Jelaskan sifat dari fosfolipid?

4. Mengapa lemak tidak jenuh lebih cepat teroksidasi (menghasilkan bau tengik) daripada lemak jenuh?

5. Bagaimana cara anda, di laboratorium, dapat mengetahui bahwa suatu lemak adalah lemak tak jenuh? 
ASAM NUKLEAT

\begin{tabular}{|l|lll|}
\hline \multicolumn{2}{|l|}{ Tujuan Instruksional } & \multicolumn{3}{l|}{ Materi } \\
\hline Mahasiswa memahami & 5.1 & Pendahuluan & \\
tentang asam nukleat & 5.2 & Komponen & Penyusun Asam \\
sehinggarapat & & Nukleat & \\
diterapkan dapat & dalam & 5.3 & Nukleosida \\
bidang kesehatan sesuai & 5.4 & Nukleotida \\
dengan perkembangan & 5.5 & Asam Nukleat \\
sains dan teknologi. & 5.6 & Fungsi Asam Nukleat \\
& 5.7 & DNA \\
& 5.8 & RNA \\
& 5.9 & Nukleoprotein \\
\hline
\end{tabular}

\subsection{Pendahuluan}

Penelitian DNA telah dimulai pada tahun 1869 seorang ilmuawan Friedrich Miescher mengisolasi zat baru dari inti sel darah putih. Kemudian Pada tahun 1879 ahli biologi Jerman Wealther Flemming menemukan struktur seperti benang yang dikenal dengan kromosom. Pada tahun 1930 peneliti Swedia Torbjorn Caspersson dan Einar Hammersten dapat menunjukkan bahwa DNA adalah polimer. Pada tahun 1951 Wilkins dan Rosalind Franklin menghasilkan gambar DNA terbaik dan menunjukkan gagasan bahwa molekul DNA melingkar menjadi bentuk heliks.

Asam nukleat adalah polimer yang tersusun dari sejumlah nukleotida.Asam nukleat merupakan makromolekul biokimia yang kompleks, berbobot molekul tinggi, dan tersusun atas rantai nukleotida yang mengandung informasi genetik. Asam nukleat ditemukan pada semua sel hidup serta pada virus dan berperan 
penting dalam biosintesis protein. Dinamakan Asam nukleat karena berada di dalam inti (nukleus) sel.

Asam Nukleat dibagi menjadi dua kelompok besar yakni Deoxyribonucleic Acid atau Asam Deoksiribonukleat (DNA) dan Ribonucleic Acid atau Asam Ribonukleat (RNA). Dilihat dari strukturnya, perbedaan di antara kedua macam asam nukleat ini terletak pada komponen gula pentosanya.Perbedaan struktur lainnya antara DNA dan RNA adalah pada basa nitogrennya. Pada DNA dan RNA, purin terdiri atas adenin(A) dan guanin (G). Akan tetapi, untuk pirimidin ada perbedaan antara DNA dan RNA.Pada DNA basa pirimidin terdiri atas sitosin (C) dan timin ( $T$ ), sedangkan pada RNA terdiri atas sitosin (C)danurasil (U).

DNA dan RNA bersifat asam sehingga disebut asam nukleat (Nucleic Acid). DNA dan RNA merupakan anion yang terikat pada protein yang mempunyai sifat basa. Senyawa gabungan antara asam nukleat dan protein disebut nukleoprotein

\subsection{Komponen Penyusun Asam Nukleat}

\section{A. Gula Pentosa}

Gula pentosa penyusun asam nukleat adalah ribosa dan deoksiribosa. Apabila gula pentosa yang terikat adalah $\beta$-D-ribosa maka dihasilkan senyawa ribonukleosida sebagai penyusun RNA, sedangkan jika gula pentosa yang terikat adalah $\beta$-D-deoksiribosa maka senyawa yang dihasilkan adalah deoksiribosanukleosida sebagai penyusun DNA. 


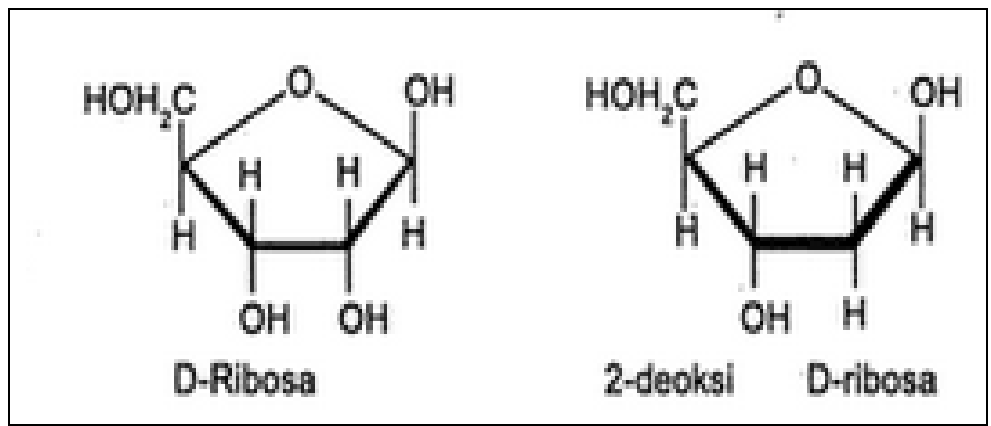

Gambar 5.1 Gambar Gula Pentosa penyusun Asam Nukleat (Harper, 1980)

\section{B. Fosfat}

Fosfat penyusun asam nukleat adalah asam fosfat atau asam ortofosfat. Fosfat berbentuk kristal orto-rombik, tak stabil dan melebur pada suhu $42,35^{\circ} \mathrm{C}$.

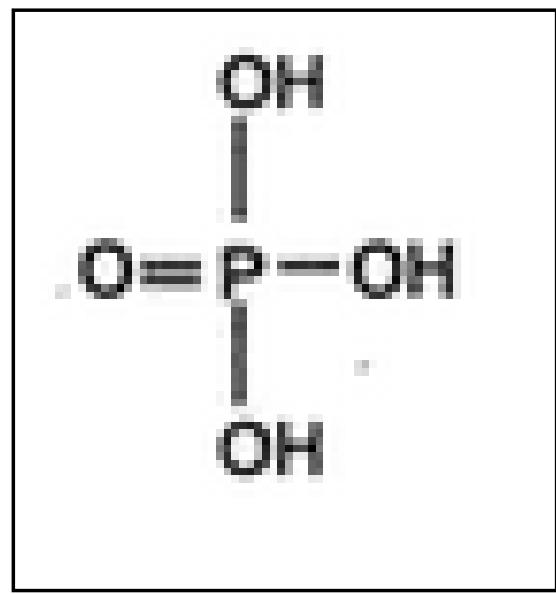

Gambar 5.2 Struktur Fosfat (Fessenden, 1986)

\section{Basa Nitrogen}

Basa Nitrogen heterosiklik merupakan penyusun asam nukleat yang tersusun dari turunan purin dan turunan 
pirimidin. Turunan purin penyusun asam nukleat adalah adenin (A) dan guanin (G). Adenin dan guanin terdapat dalam jaringan hewan dan tumbuhan.

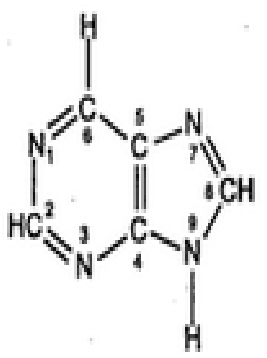

Purin<smiles>Nc1ncnc2[nH]cnc12</smiles>

$\operatorname{Adenin}(A)$<smiles>Nc1nc2[nH]cnc2c(=O)[nH]1</smiles>

Guanin (G)

Gambar 5.3 Struktur Turunan Purin (Harper, 1980)

Turunan pirimidin penyusun asam nukleat adalah sitosin (C), timin $(T)$ dan urasil $(U)$.

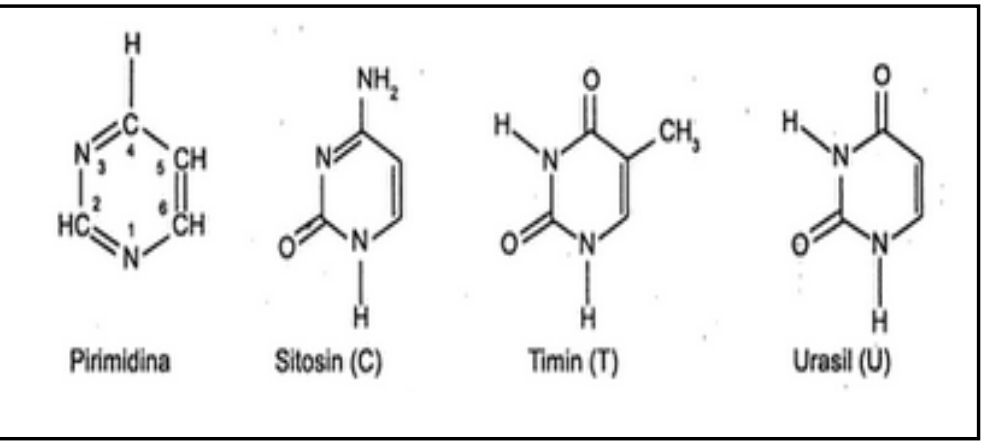

Gambar 5.3 Struktur Turunan Pirimidin (Harper, 1980) 


\subsection{Nukleosida}

Nukleosida adalah basa organik yang mengikat pentosa.

Pada purin nukleosida, ikatan glikosil terjadi antara atom N9 dari purin dan atom C1 dari gula pentosa.

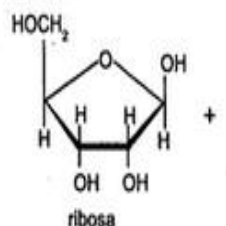

ribosa

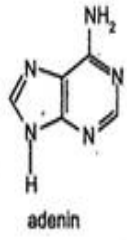

adenin

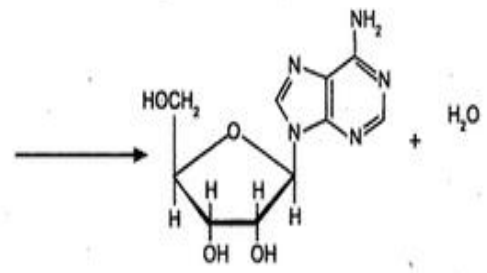

adenosin

Gambar 5.4 Ikatan antara purin dan gula pentosa (Harper, 1980)

Pada pirimidin nukleosida, ikatan glikosil terjadi antara atom N1 dari pirimidin dan atom C1 dari gula pentosa.

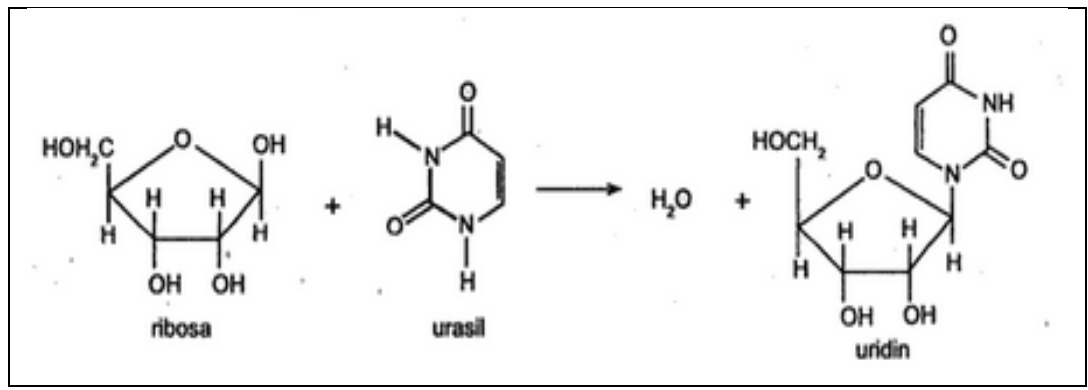

Gambar 5.4 Ikatan antara pirimidin dan gula pentosa (Harper, 1980) 
Nukleosida dibedakan menjadi 2 yaitu :

\section{a. Deoksiribonukleosida}

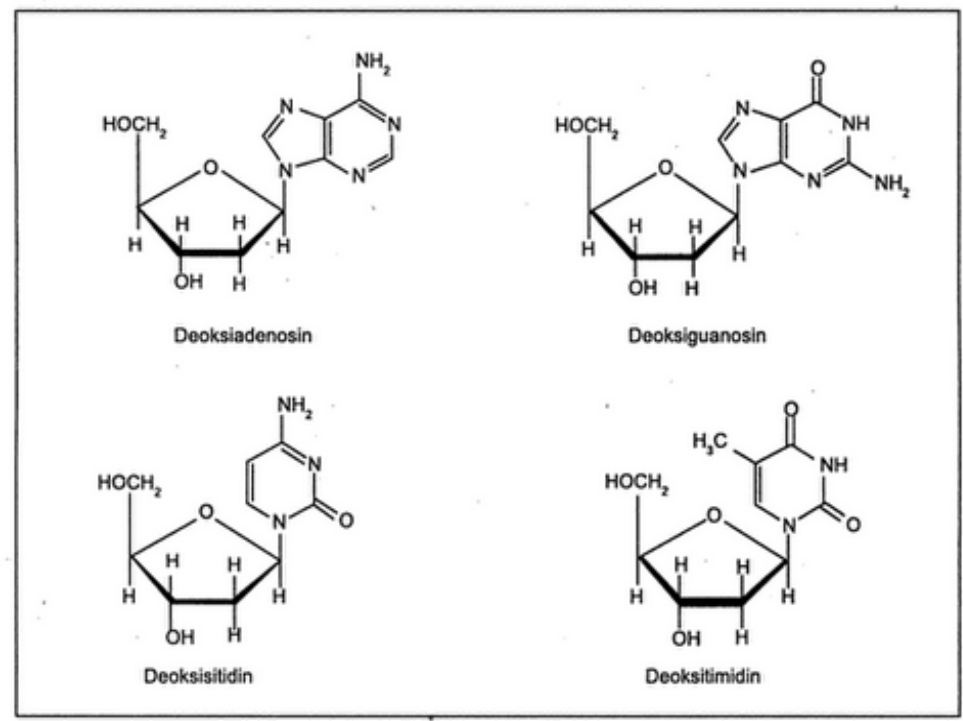

Gambar 5.5 Struktur Deoksiribonukleosida (Harper, 1980) 


\section{b. Ribonukleosida}

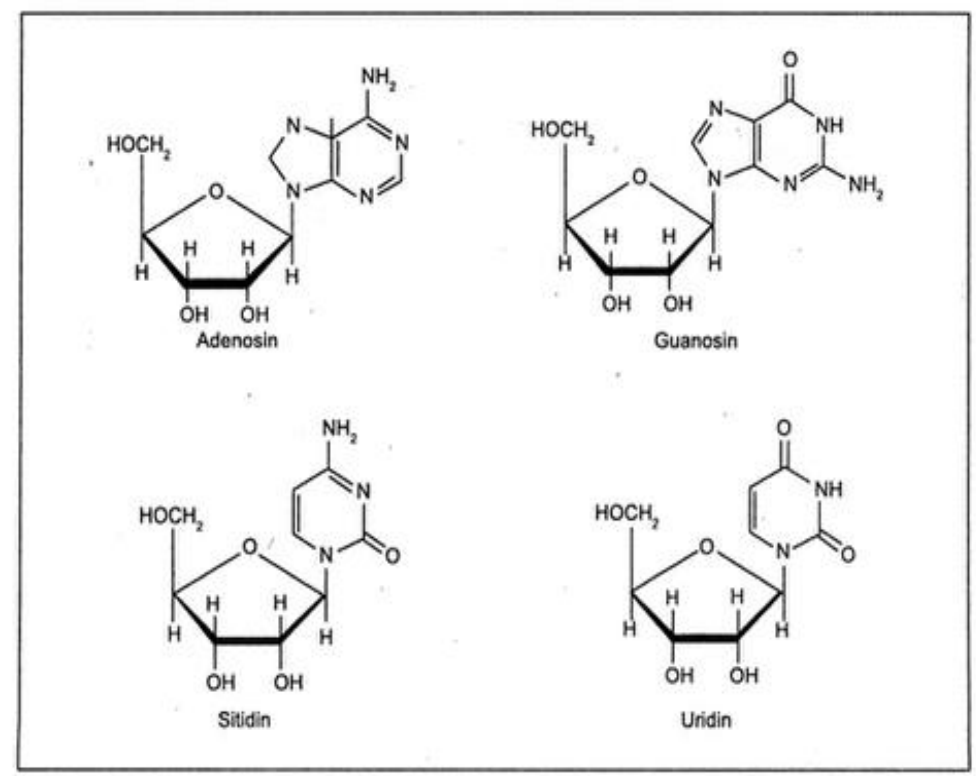

Gambar 5.6 Struktur Deoksiribonukleosida (Harper, 1980) 


\section{$5.4 \quad$ Nukleotida}

Nukleotida adalah basa organik yang mengikat pentosa dan fosfat. Nukleotida dibedakan menjadi :

a. Deoksiribonukleotida

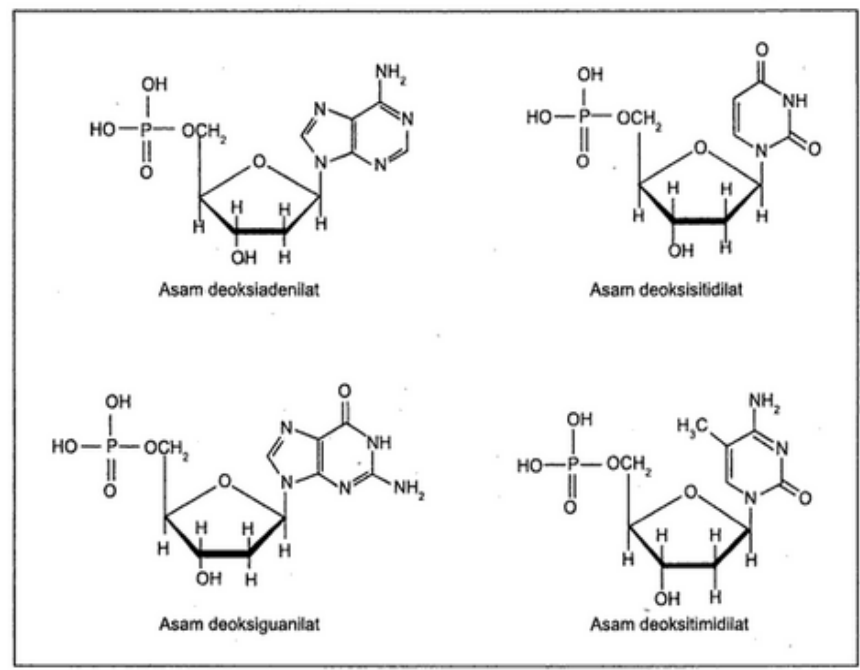

Gambar 5.7 Struktur Deoksiribonukleotida (Harper, 1980) 
b. Ribonukleotida

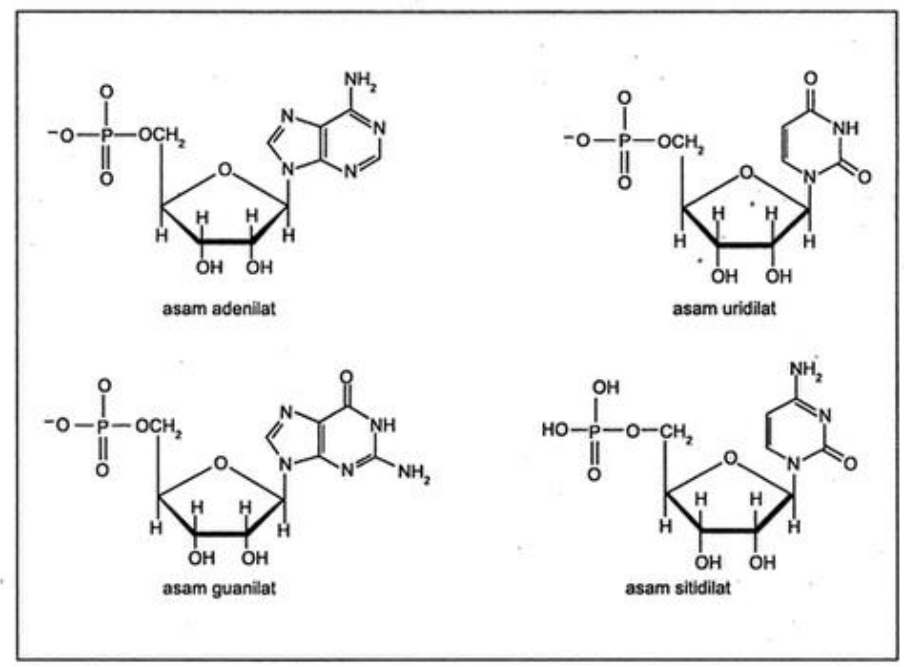

Gambar 5.8 Struktur Ribonukleotida (Harper, 1980)

Nukeotida mempunyai beberapa peranan yaitu:

a. Merupakan senyawa yang kaya energi yang sangat diperlukan dalam proses metabolisme (ATP, ADP)

b. Berperan sebagai signal kimiawi yang menghubungkan respon sel terhadap hormon maupun menangkap stimulus dan luar sel (cAMP)

c. Komponen struktural dan beberapa koenzim (NAD, $\mathrm{NADH})$

\subsection{Asam Nukleat}

Asam Nukleat adalah polimer mononukleotida. Polinukleotida mempunyai struktur tulang punggung bagi DNA dan RNA yang terdiri dari gugus pentosa dan asam fosfat secara bergantian dengan ikatan ester, sedangkan gugus basa purin dan pirimidin merupakan rantai samping dan terikat pada gugus 
pentosa pada tulang punggung tersebut. Ikatan fosfodiester menghubungkan hidroksi 3' pada nukleotida yang satu dengan gugus hidroksil 5' pada nukleotida berikutnya.

Pada kondisi $\mathrm{pH}$ yang ekstem atau pada suhu diatas $80-90^{\circ}$ C, jalin ganda DNA atau RNA dapat mengalami denaturasi, yakni lepasnya ikatan hidrogen antara basa yang berpasangan. Jika suhu kembali normal (kurang dari $60^{\circ} \mathrm{C}$ ) dan $\mathrm{pH} 7$, rangkaian DNA atau RNA yang mengalami denaturasi dapat bergabung kembali membentuk jalin ganda melalui proses annealing. Proses denaturasi atau melting untuk masing-masing DNA mempunyai nilai tengah temperatur tm yang berbeda, tergantung dan $\mathrm{PH}$ dan jumlah pasangan $\mathrm{G}=\mathrm{C}$

Tabel 5.1 Perbedaan DNA dan RNA (Harper, 1980)

\begin{tabular}{|l|l|}
\hline \multicolumn{1}{|c|}{ DNA } & RNA \\
\hline Gula pentosa deoksiribosa & Ribosa \\
\hline Bentuk DNA double heliks & Bentuk RNA rantai tunggal \\
\hline
\end{tabular}

\subsection{Fungsi Asam Nukleat}

A. Fungsi utamanya adalah menyimpan dan mentransfer informasi genetik.

B. Untuk menggunakan informasi genetik untuk mengarahkan sintesis protein baru.

C. Asam deoksiribonukleat adalah penyimpanan untuk tempat untuk informasi genetik dalam sel.

D. DNA mengontrol sintesis RNA di dalam sel.

E. Informasi genetik yang ditransmisikan dari DNA ke pembentukan protein dalam sel.

F. RNA juga mengarahkan produksi protein baru dengan mengirimkan informasi genetik pada struktur bangunan protein. 
G. Fungsi dari urutan basa nitrogen dalam tulang punggung DNA menentukan protein yang disintesis.

H. Fungsi dari heliks ganda DNA adalah bahwa tidak ada gangguan terjadi pada informasi genetik jika hilang atau rusak.

I. RNA mengarahkan sintesis protein.

J. m-RNA mengambil pesan genetik dari RNA.

K. transfer t-RNA mengaktifkan asam amino, ke tempat sintesis protein.

L. r-RNA sebagian besar hadir dalam ribosom, dan bertanggung jawab atas stabilitas m-RNA.

\subsection{DNA}

DNA mempunyai berat molekul sampai jutaan (7 juta) dengan struktur dobel heliks yang panjangnya mencapai $30.000 \mathrm{~A}$ dan lebar 15-20 A.

DNA mempunyai struktur jalin ganda (double helix). Sifatsifat spesifik dari basa N pada DNA menentukan struktur rangkaian DNA. DNA membentuk jalin ganda heliks yang berputar ke arah kanan pada porosnya dengan pola yang teratur berupa 2 periode uliran (koil). Periode pertama uliran berjarak 0,34 nm, sedangkan uliran kedua berjarak 3,6 $\mathrm{nm}$. Adanya pola uliran tersebut menyebabkan terbentuknya struktur cekungan besar (major groove) dan cekungan kecil (minor groove). Dua rangkaian DNA yang membentuk jalin ganda tersebut mempunyai arah ikatan fosfodiester 5', 3' yang benlawanan (antiparalel) yakni 5',3' dan 3',5'. DNA dapat membentuk 3 struktur yang berbeda. DNA mempunyai struktur yang fleksibel tergantung dari posisi ikatan fosfodiester yang menghubungkan gula dan fosfat. Ada tiga struktur DNA, yaitu: 
a. Bentuk A, mempunyai jarak uliran (koil) 0,23 m per pasangan basa, tersusun oleh 11 pasang basa, dan arah uliran ke kanan

b. Bentuk B, merupakan stnuktur umum DNA, mempunyai jarak uliran 0,34 $\mathrm{nm}$ per pasangan basa, tersusun oleh 10,5 pasang basa dan arah uliran ke kanan.

c. Bentuk Z, hanya dijumpai pada DNA yang berperan spesifik, jarak uliran 0,38 $\mathrm{nm}$ per pasangan basa, tersusun 12 pasang basa dan anah ulinan ke kiri.

DNA berfungsi sebagai pemyimpan informasi genetik. DNA memiliki komposisi $\mathrm{N}$ yang berbeda-beda Berdasarkan penelitian Erwin Chargaff dkk (1940) hasilkan 4 hal yang berkaitan dengan komposisi basa $\mathrm{N}$ pada DNA:

a. Komposisi bass N DNA umumny bervariasi dari satu spesies dengan spesies yang lain.

b. DNA suatu spesimen yang diisolasi dari jaringan yang berbeda dari suatu spesies yang sama mempunyai komposisi basa $\mathrm{N}$ yang sama.

c. Komposisi basa $\mathrm{N}$ pada DNA suatu spesies tidak berubah akibat umur organisme, status nutrisi atau perubahan lingkungan.

d. Semua DNA (tidak tergantung spesiesnya) mempunyai jumlah residu adenin (A) yang sama dengan ressidu timin $(A=T)$, sedang jumlah residu guanin akan sama dengan residu sitosin ( $G=C$ ). Jumlah punin sama dengan jumlah pinimidin atau $A$ $+\mathrm{G}=\mathrm{T}+\mathrm{C}$ (rumusan Chargaff) 


\section{Struktur DNA}

a. Struktur Primer DNA

Struktur Primer DNA adalah suatu untaian rantai deoksiribonukleotida. Untaian ini mempunyai struktur tulang punggung (back bone) yang terdiri dari gugus pentosa dan asam fosfat secara bergantian dengan ikatan ester, sedangkan gugus basa purin dan pirimidin merupakan rantai samping dan terikat pada gugus pentosa pada tulang punggung tersebut. Ikatan fosfodiester menghubungkan hidroksi 3' pada nukleotida yang satu dengan gugus hidroksil $5^{\prime}$ pada nukleotida berikutnya.

b. Struktur Sekunder DNA

Struktur sekunder adalah interaksi antara basa. Struktur ini menunjukkan bagian mana helai terikat satu sama lain. Kedua untai DNA dalam double heliks DNA terikat satu sama lain dengan batas hidrogen. Nukleotida pada pasangan basa satu untai dengan nukleotida untai lainnya. Struktur sekunder DNA didominasi pasangan basa dua helai polinukleotida membentuk double heliks.

c. Struktur Tersier DNA

Struktur tersier adalah bentuk tiga dimensi di mana seluruh rantai dilipat. Pengaturan struktur tersier berbeda dalam empat bentuk struktural:

2. Tangan Kiri atau kanan

3. Panjang pergantian heliks.

4. Jumlah pasangan basa per giliran.

5. Perbedaan ukuran antara utama dan alur kecil.

d. Struktur Kuarter

Struktur Kuarter adalah tingkat yang lebih tinggi dari organisasi asam nukleat. Struktur ini mengacu pada 
interaksi asam nukleat dengan molekul lain. Organisasi yang paling sering terlihat adalah bentuk kromatin yang menunjukkan interaksi dengan protein histon kecil.

\subsection{RNA}

Terdiri dari rantai tunggal poliribonukleotida. RNA terdapat di sitoplasma dengan berat molekul rendah sekitar 100 nukleotida. RNA merupakan senyawa asam nukleat terbanyak kedua setelah DNA. RNA terdapat 3 macam yaitu :

a. tRNA (transfer-RNA)

Molekul yang kecil, basa Adenin, Guanin dan Urasil yang termetilasi. Jumlahnya hanya sedikit dari total RNA dalam sel. Berfungsi untuk mengangkut (transport) asam amino spesifik ke ribosom untuk proses sintesis protein.

b. mRNA (messenger-RNA)

Disintesis dalam inti sel pada proses transkripsi. Berfungsi sebagai pembawa informasi genetik dari DNA untuk sintesis protein.

c. rRNA (ribosomal-RNA)

Merupakan 60\% dari berat ribosom. Bagian terbanyak dari RNA dalam sel (80\%). Berfungsi bertanggung jawab atas stabilitas m-RNA.

\subsection{Nukleoprotein}

Gabungan asam nukleat dengan protein. Ikatan antara protein dengan asam nukleat mudah dilepaskan hanya dengan penambahan elektrolit/perubahan $\mathrm{pH}$. Nukleoprotein berat molekul rendah, kaya lisin, mempunyai struktur atau aktifitas yang kompleks. Contoh: Histon dan Protamin. 


\section{RANGKUMAN}

1. Asam nukleat adalah polimer yang tersusun dari sejumlah nukleotida.

2. Asam Nukleat dibagi menjadi dua kelompok besar yakni Deoxyribonucleic Acid atau Asam Deoksiribonukleat (DNA) dan Ribonucleic Acid atau Asam Ribonukleat (RNA).

3. Komponen Penyusun Asam Nukleat
a. Gula Pentosa
b. Basa Nitrogen
c. Fosfat

4. Nukleosida adalah basa organik yang mengikat pentosa.

5. Nukleotida adalah basa organik yang mengikat pentosa dan fosfat.

6. Senyawa gabungan antara asam nukleat dan protein disebut nukleoprotein

7. Struktur DNA :
a. Struktur Primer
b. Struktur Sekunder
c. Struktur Tersier
d. Struktur Kuartener 


\section{LATIHAN SOAL}

I. Isilah Jawaban Dibawah ini!

Monomer asam nukleat adalah (1).... yang terdiri dari 3 komponen yaitu (2)......, (3)....... dan (4)...... Antara monomermonomer tersebut dihubungkan dengan ikatan (5)..... Basa yang dimiliki oleh RNA adalah (6)... (7) dan (9)......... Sekuen yang terdapat pada 2 untai ganda DNA bersifat $(10) \ldots . .$.

II. Pilihlah Jawaban yang Benar!

1. Polimer yang tersusun dari sejumlah nukleotida disebut
a. Asam amino
c. Asam karboksilat
b. Asam nukleat
d. Asam glutamat

2. Ikatan antara gugus pentosa dan asam fosfat
a. Ikatan ester
c. Ikatan hidrogen
b. Ikatan fosfodiester
d. Ikatan ion

3. Basa pirimidin yang terdapat pada RNA adalah
a. Urasil
c. Guanin
b. Adenin
d. Fosfat

4. Fungsi dari m-RNA adalah

a. Menentukan protein yang disintesis

b. Mengambil pesan genetik dari RNA

c. Mengaktifkan asam amino, ke tempat sintesis protei

d. Mengontrol sintesis RNA di dalam sel

5. Fungsi dari m-RNA adalah
a. Menentukan protein yang disintesis
b. Mengambil pesan genetik dari RNA
c. Mengaktifkan asam amino, ke tempat sintesis protein
d. Mengontrol sintesis RNA di dalam sel 


\section{Cocokan Jawaban Berikut ini!}

1. Senyawa gabungan antara asam nukleat dan protein disebut......

2. Gula pentosa sebagai penyusun DNA adalah

3. Polimer yang tersusun dari sejumlah nukleotida disebut

4. Basa pirimidin penyusun asam nukleat adalah

5. Bentuk rantai pada RNA adalah

\section{Pilihan Jawaban :}
A. Deoksiribosa
B. Asam Nukleat
C. Nukleoprotein
D. Timin
E. Rantai tunggal

\section{Benar atau Salah Pernyataan Dibawah ini!}

1. Asam nukleat karena berada di dalam inti (nukleus) sel (B / S)

2. Apabila gula pentosa yang terikat adalah $\beta$-D-ribosa maka dihasilkan senyawa deoksiribosanukleosida sebagai penyusun DNA (B / S)

3. Purin penyusun asam nukleat adalah adenin $(A)$ dan guanin (G) (B / S)

4. Bentuk rantai pada DNA adalah double heliks (B / S)

5. Nukleosida adalah basa organik yang mengikat pentosa (B / S) 


\section{Jelaskan Pertanyaan dibawah ini!}

1. Jelaskan secara singkat sejarah penemuan DNA?

2. Jelaskan perbedaan nukleosida dan nukleotida?

3. Jelaskan struktur DNA?

4. Jelaskan perbedaan DNA dan RNA?

5. Jelaskan hubungan antara DNA dan RNA? 


\section{BAB VI}

\section{ENZIM}

\begin{tabular}{|l|l|}
\hline Tujuan Instruksional & Materi \\
\hline Mahasiswa memahami & 6.1 Pendahuluan \\
tentang enzim sehingga & 6.2 Sifat Enzim \\
dapat diterapkan dalam & 6.3 Klasifikasi enzim \\
bidang kesehatan sesuai & 6.4 Mekanisme kerja Enzim \\
dengan perkembangan & 6.5 Aktivitas Enzim \\
sains dan teknologi. & 6.6 Struktur Enzim \\
\hline
\end{tabular}

\subsection{Pendahuluan}

Enzim adalah protein yang dihasilkan oleh sel hidup yang mempengaruhi reaksi kimia dan berfungsi sebagai katalis dalam sistem biologi. Enzim memiliki sifat yang sangat penting yaitu memiliki daya katalitik yang sangat besar dan sangat spesifik.

\subsection{Sifat Enzim}

a. Daya Katalitik Enzim

Enzim mempunyai daya katalitik sangat besar. Enzim mampu mempercepat reaksi kimia minimal sejuta kali. Tanpa enzim, kecepatan sebagian besar reaksi kimia di dalam sistem biologi sangatlah rendah sehingga tak dapat diukur.

Daya katalitik enzim berasal dari kemampuan suatu enzim mengikat substrat untuk membentuk kompleks enzim-substrat. Tempat mengikatnya enzim dengan substrat disebut situs aktif.

b. Spesifitas Enzim

Enzim sangat spesifik, baik terhadap terhadap jenis reaksi yang dikatalisisnya maupun terhadap 
substrat atau reaktan. Satu enzim biasanya mengkatalisis satu jenis reaksi kimia saja, atau seperangkat reaksi yang sejenis. Pada reaksi enzimatik jarang terbentuk hasil samping.

c. Enzim mengalami denaturasi/kerusakan pada temperatur

d. Efektif dalam jumlah kecil

e. Tidak berubah pada waktu reaksi berlangsung

\subsection{Klasifikasi Enzim}

Enzim diklasifikasikan berdasarkan tipe reaksi dan mekanisme reaksi yang dikatalisis. Semua enzim ini diidentifikasi dengan menambahkan akhiran -ase pada nama substansi atau substrat tempat enzim bekerja.

Secara ringkas, sistem penamaan enzim menurut IUB dijelaskan sebagai berikut:

a. Reaksi dan enzim yang mengkatalisis membentuk 6 kelas, masing-masing mempunyai 4-13 subkelas

b. Nama enzim terdiri atas 2 bagian, pertama menunjukkan substrat dan kedua ditambah dengan -ase yang menunjukkan tipe reaksi yang dikatalisis. Contoh: heksosa isomerase (substrat: heksosa dengan reaksi isomerase).

c. Jika diperlukan, ditambah dengan informasi tambahan tentang reaksi dalam tanda kurung di bagian akhir nama. Contoh: 1.1.1.37 L-malat:NAD+ oksidoreduktase (dekarboksilasi).

d. Setiap enzim mempunyai nomor kode (EC) yang terdiri atas:

i. Digit pertama : kelas tipe reaksi

ii. Digit kedua : subkelas tipe reaksi

iii. Digit ketiga : sub-subkelas tipe reaksi

iv. Digit keempat : untuk enzim spesifik 
Contoh: 2.7.1.1 diuraikan menjadi:

i. Kelas 2 : transferase

ii. Subkelas 7 : transfer fosfat

iii. Subsubkelas 1 : alkohol merupakan akseptor fosfat

iv. Enzim spesifik 1 : heksokinase atau ATP:D-heksosa 6fosfotransferase Suatu enzim yang mengkatalisis pemindahan fosfat dari ATP ke gugus hidroksil atom $\mathrm{C}$ ke enam molekul glukosa.

\section{Penggolongan (Klasifikasi)}

1. Oksidoreduktase : enzime yang menolong dalam proses oksidasi dan reduksi.

a. Dehidrogenase : enzim ini memegang peranan penting dalam mengubah zatzat organik menjadi hasil-hasil oksidasi.

b. Katalase : enzim yang menguraikan hidrogen peroksida menjadi air dan oksigen.

2. Hidrolase : enzim yang menguraikan suatu zat dengan pertolongan air

a. Karbohidrase, yaitu enzim-enzim yang menguraikan golongan karbohidrat. Misalnya :

- Amilase (enzim yang menguraikan amilum menjadi maltosa)

- Maltase (enzim yang menguraikan maltosa menjadi glukosa)

- Sukrase (enzim yang mengubah sukrosa (gula tebu) menjadi glukosa dan fruktosa)

- Laktase (enzim yang mengubah laktase menjadi glukosa dan galaktosa)

- Selulase (enzim yang menguraikan selulosa menjadi selobiosa) 
- Pektinase (enzim yang menguraikan pektin menjadi asam-pektin)

b. Esterase, yaitu enzim-enzim yang memecah golongan ester

- Lipase (enzim yang menguraikan lemak menjadi gliserol dan asam lemak)

- Fosfatase (enzim yang menguraikan suatu ester hingga terlepas asam fosfat)

c. Proteinase atau Protease, yaitu enzim enzim yang menguraikan golongan protein.

- Peptidase (enzim yang menguraikan peptida menjadi asam amino)

- Gelatinase (enzim yang menguraikan gelatin)

- Renin (enzim yang menguraikan kasein dari susu)

3. Transferase : Enzim yang mengkatalisis pemindahan suatu gugus

4. Liase : Enzim yang mengkatalisis pembuangan gugus dari substrat dengan mekanisme yang lain daripada hidrolisis, dan meninggalkan ikatan rangkap.

5. Isomerase : Enzim yang mengkatalisis interkoversi isomerisomer optic, geometric, atau posisi.

6. Ligase (ligare $=$ mengikat) : Enzim yang mengkatalisis penggabungan 2 senyawa diikuti oleh pemecahan ikatan pirofosfat pada ATP atau senyawa yang sejenis. Yang temasuk golongan ini adalah enzim-enzim yang mengkatalisis reaksi pembentukan ikatan $\mathrm{C}-\mathrm{O}, \mathrm{C}-\mathrm{S}, \mathrm{C}-\mathrm{N}$ dan $\mathrm{C}-\mathrm{C}$.

7. Desmolase : Enzim yang memutuskan ikatan-ikatan C-C, C-N dan beberapa ikatan lainnya.

- Karboksilase (enzim yang mengubah asam piruvat menjadi asetaldehida) 
- Transaminase (enzim yang memindahkan gugusan amine dari suatu asam amino ke suatu asam organik sehingga yang terakhir ini berubah menjadi suatu asam amino)

\subsection{Mekanisme kerja Enzim}

\section{a. Sisi aktif enzim}

Karakteristik sisi aktif enzim

1. Bagian kecil dari enzim

2. Sisi aktif merupakan suatu cekukan yang bersifat 3 dimensi.

3. Substrat terikat pada sisi aktif dengan interaksi atau ikatan yang lemah.

4. Spesifitas enzim dipengaruhi oleh asam amino yg menyusun sisi aktif suatu enzim

2 bagian penting sisi aktif :

1. Bagian yang mengenal substrat dan kemudian mengikatnya

2. Bagian yang mengkatalisis reaksi, setelah substrat diikat oleh enzim 


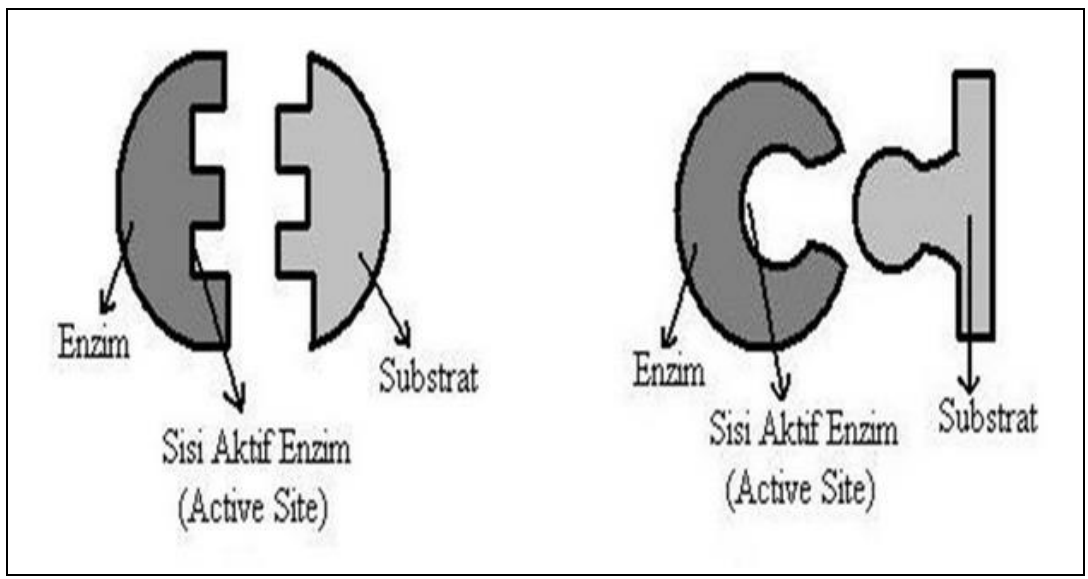

Gambar 6.1 Sisi Aktif (Harper, 1980)

\section{b. Mekanisme Reaksi Enzim}

Dua teori kerja enzim :

1. Teori lock and key (gembok-anak kunci)

Bentuk substrat sesuai dengan sisi aktif, seperti gembok cocok dengan anak kuncinya. Hal itu menyebabkan enzim bekerja secara spesifik. Substrat yang mempuyai bentuk ruang yang sesuai dengan sisi aktif enzim akan berkaitan dan membentuk kompleks transisi enzimsubstrat. Senyawa transisi ini tidak stabil sehingga pembentukan produk berlangsung dengan sendirinya.

2. Teori induced fit (kecocokan terinduksi)

Reaksi antara substrat dengan enzim berlangsung karena adanya induksi molekul substrat terhadap molekul enzim. Menurut teori ini, sisi aktif enzim bersifat fleksibel dalam menyesuaikan struktur sesuai dengan struktur substrat.

Ketika substrat memasuki sisi aktif enzim, maka enzim akan terinduksi dan kemudian mengubah bentuknya sedikit 
sehingga mengakibatkan perubahan sisi aktif yang semula tidak cocok menjadi cocok (fit). Kemudian terjadi pengikatan substrat oleh enzim, yang selanjutnya substrat diubah menjadi produk. Produk kemudian dilepaskan dan enzim kembali pada keadaan semula, siap untuk mengikat substrat baru.

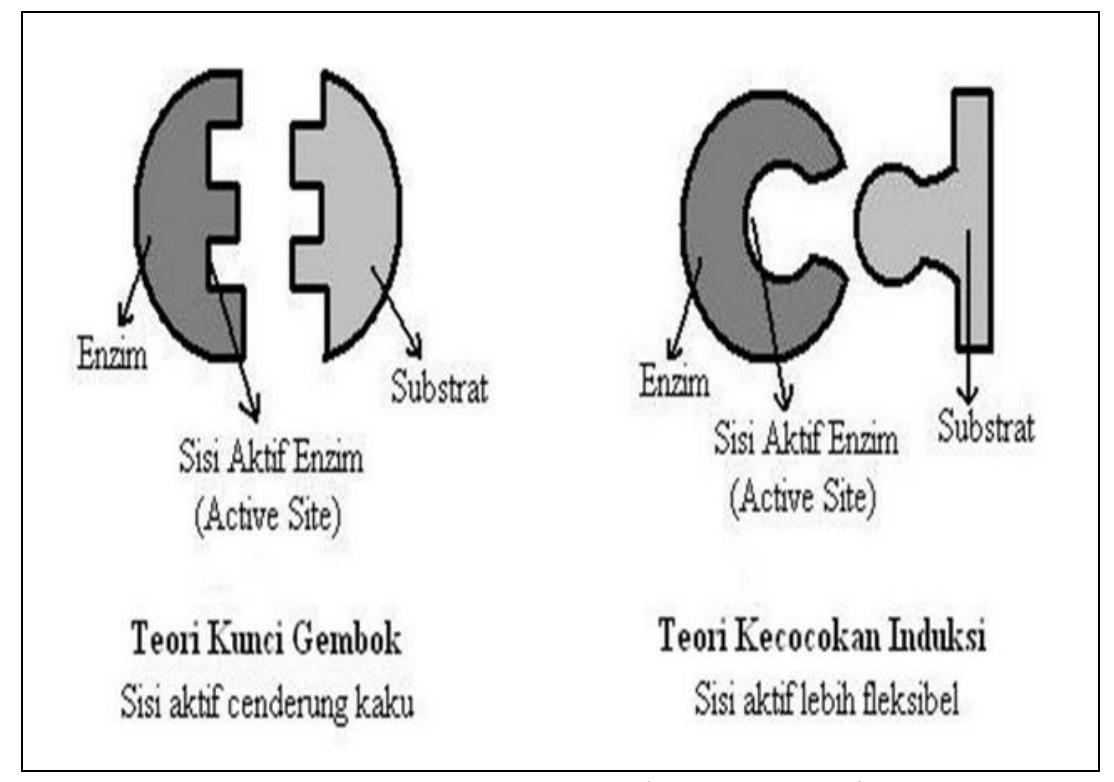

Gambar 6.2 Kerja Enzim (Harper, 1980)

\subsection{Aktivitas Enzim}

Enzim dapat bekerja dengan beberapa cara yaitu dengan :

1. Menurunkan energi aktivasi dengan menciptakan suatu lingkungan yang mana keadaan transisi terstabilisasi (contohnya mengubah bentuk substrat menjadi konformasi keadaan transisi ketika ia terikat dengan enzim) 
2. Menurunkan energi keadaan transisi tanpa mengubah bentuk substrat dengan menciptakan lingkungan yang memiliki distribusi muatan yang berlawanan dengan keadaan transisi.

3. Menyediakan lintasan reaksi alternatif. Contohnya bereaksi dengan substrat sementara waktu untuk membentuk kompleks Enzim-Substrat antara.

4. Menurunkan perubahan entropi reaksi dengan menggiring substrat bersama pada orientasi yang tepat untuk bereaksi. Menariknya, efek entropi ini melibatkan destabilisasi keadaan dasar, dan kontribusinya terhadap katalis relatif kecil.

Faktor-faktor yang memengaruhi enzim dan aktivitas enzim sebagai berikut :

1. Temperatur atau suhu Umumnya enzim bekerja pada suhu yang optimum. Apabila suhu turun, maka aktivitas akan terhenti tetapi enzim tidak rusak. Sebaliknya, pada suhu tinggi aktivitas menurun dan enzim menjadi rusak.

2. Air

Air berperan dalam memulai kegiatan enzim. Contoh pada waktu biji dalam keadaan kering kegiatan enzim tidak kelihatan. Baru setelah ada air, melalui imbibisi mulailah biji berkecambah.

3. $\mathrm{pH}$

Perubahan $\mathrm{pH}$ dapat membalikkan kegiatan enzim, yaitu mengubah hasil akhir kembali menjadi substrat.

4. Hasil akhir

Kecepatan reaksi dalam suatu proses kimia tidak selalu konstan. Misal, kegiatan pada awal reaksi tidak sama 
dengan kegiatan pada pertengahan atau akhir reaksi. Apabila hasil akhir (banyak), maka akan menghambat aktivitas enzim.

5. Substrat

Substrat adalah zat yang diubah menjadi sesuatu yang baru. Umumnya, terdapat hubungan yang sebanding antara substrat dengan hasil akhir apabila konsentrasi enzim tetap, $\mathrm{pH}$ konstan, dan temperatur konstan. Jadi, apabila substrat yang tersedia dua kali lipat, maka hasil akhir juga dua kali lipat.

6. Zat -zat penghambat

Zat-zat penghambat adalah zat-zat kimia yang menghambat aktivitas kerja enzim. Contohnya garamgaram dari logam berat

\subsection{Struktur Enzim}

\section{Berdasarkan tempat kerjanya, enzim dibedakan :}

a. Eksoenzim ialah enzim yang aktivitasnya diluar sel.

b. Endoenzim ialah enzim yang aktivitasnya didalam sel.

Berdasarkan ada atau tidaknya substrat, enzim dibedakan :

a. Enzim konstitutif ialah enzim yang dibentuk terus-menerus oleh sel tanpa peduli apakah substratnya ada atau tidak.

b. Enzim induktif (enzim adaptif) ialah enzim yang dibentuk karena adanya rangsangan substrat atau senyawa tertentu yang lain

\section{Isoenzim}

Isoenzim adalah protein yang dapat mengkatalisis reaksi yang sama dan terjadi pada spesies yang sama, tetapi mempunyai sifat-sifat fisika dan kimia yang berbeda. 


\section{Kofaktor}

- Kofaktor adalah Komponen selain protein pada enzim. Ion logam pada kofaktor berfungsi untuk menjadi pusat katalis primer, menjadi tempat untuk mengikat substrat, dan sebagai stabilisator supaya enzim tetap aktif

- Holoenzim adalah Gabungan antara bagian protein enzim (apoenzim) dan kofaktor

- Metaloenzim adalah Enzim yang memerlukan ion logam sebagai kofaktornya

Tabel 6.1 Contoh Kofaktor (Harper, 1980)

\begin{tabular}{|l|l|}
\hline Ion logam & Enzim \\
\hline $\mathrm{Zn}^{2+}$ & $\begin{array}{l}\text { Alkohol dehidrogenase } \\
\text { Karbonat anhidrasa } \\
\text { Karboksipeptidasa } \\
\mathrm{Mg}^{2+}\end{array}$ \\
$\mathrm{Fe}^{2+} / \mathrm{Fe}^{3+}$ & $\begin{array}{l}\text { Fosfohidrolasa } \\
\text { Fosfotransferasa } \\
\text { Sitokrom } \\
\text { Peroksida } \\
\text { Katalasa } \\
\text { Feredoksin } \\
\text { Tirosina } \\
\text { Sitokrom oksidasa } \\
\mathrm{Cu}^{2+} / \mathrm{Cu}^{+}\end{array}$ \\
$\mathrm{K}^{+}$ & $\begin{array}{l}\text { Piruvat kinasa (juga memerlukan } \mathrm{Mg}^{2+} \text { ) } \\
\text { Membrane sel ATPasa ( juga memerlukan } \mathrm{K}^{+} \text {dan } \\
\text { Mg }\end{array}$ \\
\hline $\mathrm{Na}^{+}$ & \\
\hline
\end{tabular}




\section{Koenzim}

Koenzim merupakan ion logam/ metal, atau molekul organik. koenzim yang berperan sebagai pemindah hidrogen, pemindah elektron, pemindah gugusan kimia tertentu

Gugus Prostetik adalah Koenzim yang berikatan secara erat dengan enzim melalui ikatan kovalen atau non kovalen

Tabel 6.2 Contoh Koenzim (Harper, 1980)

\begin{tabular}{|l|l|l|l|}
\hline No & Kode & \multicolumn{1}{|c|}{ Singkatan dari } & \multicolumn{1}{|c|}{$\begin{array}{c}\text { Yang } \\
\text { dipindahkan }\end{array}$} \\
\hline 1. & NAD & Nikotinamida-adenina dinukleotida & Hidrogen \\
\hline 2. & NADP & $\begin{array}{l}\text { Nikotinamida-adenina dinukleotida } \\
\text { fosfat }\end{array}$ & Hidrogen \\
\hline 3. & FMN & Flavin mononukleotida & Hidrogen \\
\hline 4. & FAD & Flavin-adenina dinukleotida & Hidrogen \\
\hline 5. & Ko-Q & Koenzim Q atau Quinon & Hidrogen \\
\hline 6. & Sit & Sitokrom & Elektron \\
\hline 7. & Fd & Ferredoksin & Elektron \\
\hline 8. & ATP & Adenosina trifosfat & Gugus fosfat \\
\hline 9. & PAPS & Fosfoadenil sulfat & Gugus sulfat \\
\hline 10. & UDP & Uridina difosfat & Gula \\
\hline
\end{tabular}




\section{Rangkuman}

1. Enzim adalah protein yang dihasilkan oleh sel hidup yang mempengaruhi reaksi kimia dan berfungsi sebagai katalis dalam sistem biologi

2. Sifat Enzim ada 2 yaitu daya katalitik enzim dan spesifitas enzim

3. Klasifikasi Enzim berdasarkan tipe reaksi dan mekanisme reaksi yang dikatalisis

4. Mekanisme Reaksi Enzim :

Teori lock and key (gembok-anak kunci)

Teori induced fit (kecocokan terinduksi) 


\section{LATIHAN SOAL}

\section{Pilihlah Jawaban yang Benar!}

1. Enzime yang menolong dalam proses oksidasi dan reduksi disebut
a. Oksidoreduktase
c. Amilase
b. Hidrolase
d. Sukrosa

2. Enzim yang memerlukan ion logam sebagai kofaktornya
a. Holoenzim
c. Apoenzim
b. Metaloenzim
d. Koenzim

3. Kofaktor yang dibutuhkan oleh enzim karbonat anhidrase adalah
a. $\mathrm{Fe}^{2+}$
C. $\mathrm{Zn}^{2+}$
b. $\mathrm{K}^{+}$
d. $\mathrm{Mg}^{2+}$

4. Fungsi koenzim ATP adalah
a. Memindahkan hidrogen
b. Memindahkan elektron
c. Memindahkan gugus fosfat
d. Memindahkan gula

5. Berikut adalah cara enzim bekerja, kecuali

a. Menurunkan energi aktivasi dengan menciptakan suatu lingkungan yang mana keadaan transisi terstabilisasi

b. Menurunkan energi keadaan transisi tanpa mengubah bentuk substrat

c. Mengaktifkan asam amino, ke tempat sintesis protein

d. Menyediakan lintasan reaksi alternatif 


\section{Cocokan Jawaban Berikut ini!}

1. Tempat mengikatnya enzim dengan substrat disebut

2. Enzim yang menguraikan hidrogen peroksida menjadi air dan oksigen disebut

3. Salah satu contoh koenzim adalah

4. Salah satu contoh kofaktor adalah

5. Gabungan antara (apoenzim) dan kofaktor

\section{Pilihan Jawaban :}
A. Katalase
B. Situs Aktif
C. Holoenzim
D. FMN
E. Natrium

\section{Benar atau Salah Pernyataan Dibawah ini!}

1. Tanpa enzim, kecepatan sebagian besar reaksi kimia di dalam sistem biologi sangatlah rendah sehingga tak dapat diukur (B / S)

2. Satu enzim biasanya mengkatalisis satu jenis reaksi kimia (B / S)

3. Koenzim adalah Komponen selain protein pada enzim (B / S)

4. Kofaktor merupakan ion logam/ metal, atau molekul organik (B / S)

5. Gugus Prostetik adalah Koenzim yang berikatan secara erat dengan enzim melalui ikatan kovalen atau non kovalen (B / S) 


\section{Jelaskan Pertanyaan dibawah ini!}

1. Jelaskan mekanisme enzim?

2. Jelaskan peranan enzim untuk kehidupan?

3. Jelaskan tata cara penamaan enzim? 


\section{BAB VII}

METABOLISME

\begin{tabular}{|c|c|}
\hline Tujuan Instruksional & Materi \\
\hline $\begin{array}{l}\text { Mahasiswa memahami } \\
\text { tentang metabolisme } \\
\text { sehingga dapat } \\
\text { diterapkan dalam } \\
\text { bidang kesehatan sesuai } \\
\text { dengan perkembangan } \\
\text { sains dan teknologi. }\end{array}$ & $\begin{array}{l}\text { 7.1 Pendahuluan } \\
\text { 7.2 Metabolisme Karbohidrat } \\
\text { 7.3 Metabolisme Lemak } \\
\text { 7.4 Metabolisme Ptotein }\end{array}$ \\
\hline
\end{tabular}

\subsection{Pendahuluan}

Metabolisme adalah proses kimia yang terjadi di dalam tubuh makhluk hidup/sel. Metabolisme disebut juga reaksi enzimatis, karena reaksi metabolisme menggunakan katalisator enzim.

Berdasarkan prosesnya metabolisme dibagi menjadi 2, yaitu

1. Anabolisme/ Asimilasi/ Sintesis yaitu proses pembentukan molekul yang kompleks dengan menggunakan energi tinggi.

2. Katabolisme (Dissimilasi) yaitu proses penguraian zat untuk membebaskan energi kimia yang tersimpan dalam senyawa organik tersebut

\subsection{Metabolisme Karbohidrat}

Glukosa dalam darah masuk lewat vena porta hepatica kemudian masuk ke sel hati. Selanjutnya glukosa diubah menjadi glikogen (glikogenesis). Sebaliknya, jika tubuh kekurangan glukosa, maka glikogen akan segera diubah lagi menjadi glukosa (glikogenolisis). Hal ini dapat terjadi di hati karena hati memiliki 
kedua enzim yang berperan dalam katabolisme maupun anabolisme karbohidrat.

Glukagon berperan merangsang proses glikogenolisis dan glukoneogenesis. Insulin berperan untuk meningkatkan sintesis glikogen. Makanan yang banyak mengandung karbohidrat akan merangsang sekresi insulin dan mencegah sekresi glukagon. Insulin berfungsi mempermudah dan mempercepat masuknya glukosa ke dalam sel dengan meningkatkan afinitas molekul karier glukosa. Glukosa setelah berada di dalam sel, oleh insulin akan disimpan atau disintesis menjadi glikogen baik di hati, otot, atau jaringan lain.

\section{Glikogenesis}

Glukosa setelah masuk ke dalam sel akan bergabung dengan gugus posfat radikal menjadi Glu-6-P (Posforilasi):

$$
\text { Glukosa + Posfat } \rightarrow \text { Glu-6-Posfat }
$$

Posforilasi glukosa tersebut bersifat reversibel. Glu-6-P dapat langsung digunakan untuk sumber energi atau disimpan dalam bentuk glikogen. Jika konsumsi karbohidrat berlebihan sehingga intake glukosa melimpah sedangkan pembongkaran glukosa untuk sumber tenaga berkurang, maka glukosa akan diubah menjadi glikogen (glikogenesis). Glikogenesis diregulasi oleh insulin. Pembentukan glikogen dapat terjadi di semua sel tubuh terutama di hati dan otot (5-8 \% dari seluruh sel). Selain itu, glukosa dapat dipecah menjadi asetil Ko-A kemudian diubah menjadi lemak yang kemudian disimpan di dalam hati dan jaringan adiposa (lemak) terutama di peritoneum. 


\section{Glikolisis}

Glukosa di dalam sitoplasma akan dipecah secara enzimatis berantai menjadi asam piruvat dengan menghasilkan 2 mol ATP. Proses ini disebut respirasi anaerob (glykolisis anaerob) yaitu:

1. Jalur Embden Meyerhof

2. Heksosamonoposfat shunt

Asam piruvat selanjutnya akan mengalami beberapa kemungkinan diubah menjadi:

1. Asam laktat dengan menghasilkan 2 mol ATP. Peristiwa ini meningkat pada saat tubuh kekurangan oksigen, misalnya pada saat latihan atau bekerja terlalu keras. Asam laktat yang dihasilkan ini dapat menurunkan $\mathrm{pH}$ yang akan mempengaruhi daya hidup sel.

2. Asetaldehida kemudian menjadi alkohol. Proses ini disebut fermentasi (hanya terjadi pada bakteri, jamur dan tumbuhan).

3. Asetil Ko-A selanjutnya siklus Kreb's dan transport electron menjadi ATP.

\section{Glikogenolysis}

Pada saat seseorang berpuasa atau sedang melakukan aktivitas (latihan olahraga, bekerja) yang berlebihan akan menyebabkan turunnya kadar glukosa darah menjadi 60 $\mathrm{mg} / 100 \mathrm{ml}$ darah. Keadaan ini (kadar gula darah turun) akan memacu hati untuk membebaskan glukosa dari pemecahan glikogen yang disebut proses glikogenolysis. Glikogenolysis dirangsang oleh hormon glukagon dan adrenalin. 


\section{Glukoneogenesis}

Apabila ketersediaan glukosa tidak tercukupi, maka lemak dan protein akan diubah menjadi asetil koenzim A (Asetil Ko-A) sehingga dapat masuk ke siklus Kreb's. Peristiwa pembentukan glukosa dari asam amino dan asam lemak disebut glukoneogenesis.

\section{Respirasi (Okisidasi) Seluler}

Glukosa di dalam sel dipecah secara oksidasi dengan menggunakan molekul oksigen menjadi karbondioksida (CO2), air (H2O), energi (ATP), dan panas. Jika kadar oksigen tercukupi, maka asam piruvat selanjutnya akan diubah menjadi asetil koenzim $A$ (Asetil Ko-A) sehingga dapat masuk ke siklus Kreb's, atau setelah menjadi asetil Ko-A kemudian masuk ke dalam siklus Kreb's dengan menghasilkan NADH (nicotin amid dinucleotid), FAD (Flavin adenin dinucleotid), ATP (adenosin trifosfat), $\mathrm{CO} 2$ dan $\mathrm{H} 2 \mathrm{O}$. Peristiwa ini terjadi di dalam mitokondria atau sering disebut respirasi seluler.

$$
\mathrm{C} 6 \mathrm{H} 12 \mathrm{O} 6+6 \mathrm{O} 2 \rightarrow 6 \mathrm{CO} 2+6 \mathrm{H} 2 \mathrm{O}+36 \mathrm{ATP}+\text { Panas }
$$

Transport electron: mengubah NADH dan FADH menjadi ATP di dalam membran dalam mitokondria. Satu mol glukosa akan menghasilkan sebanyak 36 mol ATP (netto). Satu mol glukosa (180 gr glukosa) menghasilkan 686.000 kalori setara 36 ATP. Selain dari glukosa, ATP dapat dihasilkan dari pemecahan asam lemak dan asam amino. 
Tabel 7.1 Jumlah ATP Yang Dihasilkan Dari Proses Respirasi (Oksidasi) Seluler

\begin{tabular}{|l|l|}
\hline Berasal dari & $\begin{array}{l}\text { Jumlah ATP } \\
\text { yang } \\
\text { dihasilkan }\end{array}$ \\
\hline 1. Glikolisis sebagai ATP & 4 \\
\hline 2. Glikolisis sebagai NADH & 4 \\
\hline 3. Perubahan asam priuvat menjadi asetil-Ko-A sebagai NADH & 6 \\
\hline 4. Siklus Kreb's sebagai GTP & 2 \\
\hline 5. Siklus Kreb's dari reduksi FAD & 4 \\
\hline 6. Siklus Kreb's sebagai NADH & 18 \\
\hline Jumlah Total & 38 \\
\hline Glikolisis diperlukan 2 ATP untuk memecah glukosa & -2 \\
\hline Jumlah Bersih (netto) & 36 \\
\hline
\end{tabular}

\subsection{Metabolisme Lemak}

Kolesterol makanan dalam wujud sebagai kolesterol ester. Asam lemak setelah diserap oleh sel mukosa usus halus dengan cara difusi, kemudian di dalam sel mukosa asam lemak dan gliserol mengalami resintesis (bergabung lagi) menjadi trigliserida. Kolesterol juga mengalami reesterifikasi menjadi ester kolesterol. Trigliserida dan ester kolesterol bersatu diselubungi oleh protein menjadi kilomikron (chylomicron). Protein penyusun selubung kilomikron disebut apoprotein. Selubung protein berfungsi mencegah antarmolekul lemak bersatu dan membentuk bulatan besar yang dapat mengganggu sirkulasi darah.

Kilomikron keluar dari sel mukosa usus secara eksositosis (kebalikan dari pinositosis) kemudian diangkut lewat sistem limfatik dan selanjutnya masuk ke dalam sirkulasi darah (vena subclavia). Kadar kilomikron dalam plasma darah meningkat 2 - 4 jam setelah makan. Kilomikron di dalam pembuluh darah dihidrolisis oleh enzim lipase endotel menjadi menjadi asam lemak (FFA) dan gliserol.

FFA dibebaskan dari kilomikron dan selanjutnya disimpan dalam jaringan lemak (adipose tissue) atau jaringan perifer. 
Kilomikron yang telah kehilangan asam lemak dengan demikian banyak mengandung kolesterol dan tetap berada di dalam sirkulasi disebut chylomicron remnant (sisa kilomikron) dan akhirnya menuju ke hati yang selanjutnya didegradasi di dalam lisosom. Sedangkan gliserol langsung diabsorpsi ke pembuluh darah porta hepatic.

\section{Metabolisme kolesterol}

Kolesterol diserap perlahan-lahan dan saluran pencernaan manusia; larut dalarn lemak dan mudah membentuk ester. Kolesterol dapat berasal dan makanan (eksogen); dapat pula dibentuk oleh sel tubuh (endogen). Hampir semua kolesterol endogen dibuat oleh hepar.

Faktor yang mempengaruhi kadar kolesterol plasma:

1. Makanan,

2. Lemakjenuh, dapat menaikkan kadar kolesterol sampai $25 \%$

3. Lemak tak jenuh, dapat menurunkan kolesterol darah

4. Kekurangan insulin dan tiroksin meningkatkar kadar kolesterol darah.

Kolesterol digunakan untuk: (1) sintesis asam kolat di hepar (80\%) dan selanjutnya dipakai untuk membuat garam empedu; (2) membuat glukokortikoid, progesteron, estrogen dan testosteron. 


\subsection{Metabolisme Protein \\ Mekanisme Transaminasi}

Transaminasi adalah proses perubahan asam amino menjadi jenis asam amino lain. Proses transaminasi didahului oleh perubahan asam amino menjadi bentuk asam keto, secara skematik digambarkan sebagai berikut:

Alanin $+\alpha$-ketoglutarat $\leftrightarrow$ piruvat + glutamat

Transaminasi terjadi pada berbagai jaringan. Selain itu, transaminasi juga terjadi di dalam sirkulasi darah akibat adanya kerusakan pada jaringan karena proses patologik, sebagai contoh SGOT (serum glutamic-oxaloacetic transaminase) yang meningkat akibat infark miokard (kerusakan otot jantung karena adanya sumbatan pembuluh darah yang mensuplai kebutuhan otot jantung).

\section{Mekanisme Deaminasi}

Deaminasi oksidatif adalah proses pemecahan (hidrolisis) asam amino menjadi asam keto dan ammonia $\left(\mathrm{NH}^{4+}\right)$, secara skematik digambarkan sebagai berikut:

Asam amino $\rightarrow$ (deaminasi) $\rightarrow 2 \mathrm{NH}_{3}+\mathrm{CO}_{2} \rightarrow \mathrm{CO}\left(\mathrm{NH}_{3}\right)_{2}+\mathrm{H}_{2} \mathrm{O}$

Deaminasi menghasilkan 2 senyawa penting yaitu senyawa nitrogen dan nonnitrogen :

1. Senyawa nonnitrogen yang mengandung gugus $\mathrm{C}, \mathrm{H}$, dan $O$ selanjutnya diubah menjadi asetil Co-A untuk sumber energi melalui jalur siklus Kreb's atau disimpan dalam bentuk glikogen.

2. Senyawa nitrogen dikeluarkan lewat urin setelah diubah lebih dahulu menjadi ureum. Proses deaminasi kebanyakan terjadi di hati, oleh karena itu pada 
gangguan fungsi hati (liver) kadar $\mathrm{NH}_{3}$ meningkat. Pengeluaran (ekskresi) urea melalui ginjal dikeluarkan bersama urin.

\section{Rangkuman}

1. Metabolisme adalah proses kimia yang terjadi di dalam tubuh makhluk hidup/sel.

2. Berdasarkan prosesnya metabolisme dibagi menjadi 2, yaitu :

a. Anabolisme

b. Katabolisme

\section{LATIHAN SOAL}

\section{Jelaskan Pertanyaan dibawah ini!}

1. Jelaskan mekanisme metabolisme karbohidrat, protein, dan asam lemak!

2. Berikan contoh dan penjelasan mengenai proses anabolisme!

3. Jelaskan manfaat energy yang dihasilkan dari metabolisme!

4. Jelaskan mekanisme glukoneogenesis, glikogenesis, glikogenolisis, dan glikolisis! 


\section{DAFTAR PUSTAKA}

Albert L. Lehninger. 1995. Dasar-dasar Biokimia. (Alih bahasa: Maggy Thenawidjaja). Penerbit Erlangga, Jakarta.

Buckle, K.A. 1987. Ilmu Pangan. Jakarta: Universitas Indonesia (UIPress)

Boyer, R. 1999. Concept in Biochemistry. Brooks Cole Publishing Company. Fessenden dan Fessenden.1986. Kimia Organik jilid 2 edisi ketiga. Terjemahan oleh Aloysius Hadyana Pudjaatmaka, Ph. D.1992.Jakarta : Erlangga.

Harper, et al. 1980. Biokimia (Review of Physiological Chemistry). Edisi 17. EGC: Jakarta.

Horton, H.R., Moran LA, Rawn J.D. and Scrimgeor, KG. 1996. Principle ofBiochemistry. Second Edition. Prentice-Hall International, Inc.

Lehninger, Nelson, \& Cox. 1997. Principles of Biochemistry.2nd edition. Worth Publishers.

Nelson, DL. and Cox, M.M. 2000. Lehninger: Principles of Biochemistry. Third Edition. Worth Publisher. 


\section{BIODATA PENULIS}

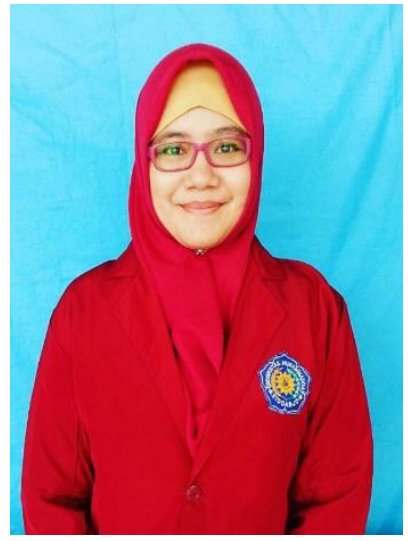

Galuh Ratmana Hanum adalah dosen mata kuliah Biokimia pada jurusan D-IV Teknologi Laboratorium Medis Fakultas Ilmu Kesehatan

Universitas Muhammadiyah Sidoarjo. Riwayat pendidikan S1 di Jurusan Kimia Universitas Negeri Surabaya tahun 2003. S2 di Jurusan Kimia Universitas Airlangga tahun 2011. 